AUTARQUIA ASSOCIADA À UNIVERSIDADE DE SÃO PAULO

RISCO DE EXPOSIÇÃO À RADIAÇÃO IONIZANTE EM CRIANÇAS E ADOLESCENTES PARTICIPANTES DE UM PROGRAMA DE CONTROLE DA ASMA EM COMPARAÇÃO À POPULAÇÃO GERAL

LETICIA GUIMARÃES CARVALHO DE SOUZA LIMA

Dissertação apresentada como parte dos requisitos para obtenção do Grau de Mestre em Ciências na Área de Tecnologia Nuclear - Aplicações

Orientador:

Prof. Dr. Carlos Alberto Zeituni 
INSTITUTO DE PESQUISAS ENERGÉTICAS E NUCLEARES

Autarquia associada à Universidade de São Paulo

RISCO DE EXPOSIÇÃO À RADIAÇÃO IONIZANTE EM CRIANÇAS E ADOLESCENTES PARTICIPANTES DE UM PROGRAMA DE CONTROLE DA ASMA EM COMPARAÇÃO À POPULAÇÃO GERAL

LETICIA GUIMARÃES CARVALHO DE SOUZA LIMA

Dissertação apresentada como parte dos requisitos para obtenção do Grau de Mestre em Ciências na Área de Tecnologia Nuclear - Aplicações

Orientador:

Prof. Dr. Carlos Alberto Zeituni 
Dedico este trabalho ao meu marido Mauro Oscar, às minhas queridas filhas Luiza e Marina e a todas as crianças e adolescentes que fazem parte do Programa Respirar. 


\section{AGRADECIMENTOS}

A Deus, pois "tudo posso naquele que me fortalece".

Ao meu esposo que, acima de tudo, proporcionou um incentivo fundamental para que este sonho se tornasse possível, com imensa compreensão e ajuda nos momentos nos quais me ausentei.

Às minhas filhas, que me deram o apoio e energia nas horas certas e por fazerem a minha existência ser completa.

Aos meus pais, exemplos motivadores e norteadores da minha caminhada.

Ao meu orientador, Professor Dr. Carlos Alberto Zeituni, que com serenidade e confiança tornou este projeto possível e tão agradável.

Aos professores membros da banca de qualificação e defesa, pelas sugestões de melhoria.

À UNIVAÇO, que proporcionou a realização do meu trabalho, disponibilizando todos os recursos necessários.

À Secretaria Municipal de Ipatinga e ao Hospital Márcio Cunha, pois a realização deste estudo somente foi possível graças à contribuição de instituições tão sérias.

A todos os médicos e enfermeiros que participam do Programa Respirar, pela força e empenho em colaborar.

A todos, o meu profundo e reconhecido obrigado. 
"A procura da verdade é difícil e é fácil, já que ninguém poderá desvendá-la por completo ou ignorá-la completamente. Contudo, cada um de nós poderá acrescentar um pouco do nosso conhecimento sobre a natureza e, disto, uma certa grandeza emergirá." 


\title{
RISCO DE EXPOSIÇÃO À RADIAÇÃO IONIZANTE EM CRIANÇAS E ADOLESCENTES PARTICIPANTES DE UM PROGRAMA DE CONTROLE DA ASMA EM COMPARAÇÃO À POPULAÇÃO GERAL
}

\author{
Leticia Guimarães Carvalho de Souza Lima
}

\begin{abstract}
RESUMO
Asma é uma doença de elevada prevalência e morbidade, constituindo-se um importante problema de saúde pública em todo o mundo. Muitos diagnósticos médicos por imagem dependem da utilização de raio $\mathrm{X}$; entretanto, no caso da asma, o diagnóstico é clínico, particularmente na criança. Os pacientes são frequentemente submetidos a procedimentos radiológicos, preferencialmente o raio $X$ de tórax. $A$ escassez de dados na literatura referentes aos riscos da exposição à radiação ionizante em pacientes com asma e os possíveis benefícios relacionados à oportunidade de coleta de informações justificaram a investigação no programa municipal infantil de controle da asma de Ipatinga, Minas Gerais (Programa Respirar). Foi realizado estudo retrospectivo referente ao ano de 2014, com caso controle, do qual participaram 363 pacientes do Programa Respirar e número semelhante de controle, sem diferença sociodemográfica significativa entre os grupos. Encontramos que uma criança do grupo respirar tem 1,59 vez mais chance de realizar um raio $X$, e para o raio $X$ de tórax essa chance aumenta para 6,56 vezes. A maioria dos raios $X$ de tórax foi solicitada nas visitas aos serviços de urgência, mas $90 \%$ dos raios $X$ realizados $e$ laudados no grupo respirar e $84,2 \%$ do grupo controle revelaram resultado normal ou com alterações típicas, possibilitando o questionamento a respeito da indicação do exame.
\end{abstract}

Palavras-chave: Asma, radiação ionizante, proteção radiológica. 


\title{
RISCO DE EXPOSIÇÃO À RADIAÇÃO IONIZANTE EM CRIANÇAS E ADOLESCENTES PARTICIPANTES DE UM PROGRAMA DE CONTROLE DA ASMA EM COMPARAÇÃO À POPULAÇÃO GERAL
}

\author{
Leticia Guimarães Carvalho de Souza Lima
}

\begin{abstract}
Asthma is a disease of high prevalence and morbidity, constituting an important public health problem throughout the world. Patients are often submitted to radiological procedures, preferably the chest $X$ ray. Many medical imaging diagnoses depend on the use of $X$ ray, however, in the case of asthma, the diagnosis is clinical, particularly in the child. The scarcity of data in the literature regarding the risks of exposure to ionizing radiation in patients with asthma and the possible benefits related to the opportunity to collect information justified the investigation in the municipal infant asthma control program in Ipatinga, Minas Gerais (Programa Respirar). A retrospective study was carried out for the year 2014, with a control case involving 363 patients from the Programa Respirar and a similar number of controls, with no significant sociodemographic difference between the groups. We found that a child in the group respirar is 1.59 time more likely to have an $X$ ray and for the chest $X$ ray this chance increases to 6.56 times. The majority of chest $X$ rays were requested at emergency department visits, but $90 \%$ of the $X$ rays performed and lauded in the Programa Respirar and $84.2 \%$ of the control group revealed normal results or with typical alterations, making it possible to question the indication of the examination.
\end{abstract}

Keywords: Asthma; ionizing radiation; radiation protection. 


\section{SUMÁRIO}

Página

1 INTRODUÇÃO

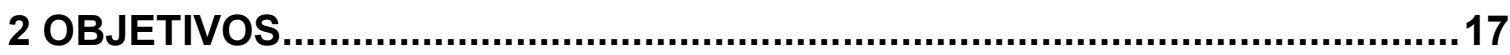

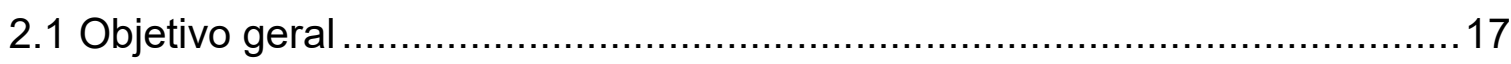

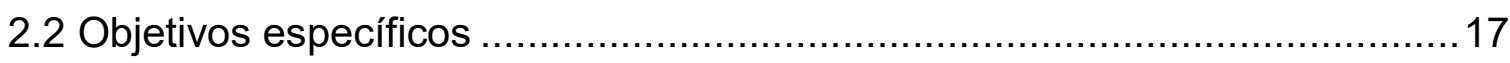

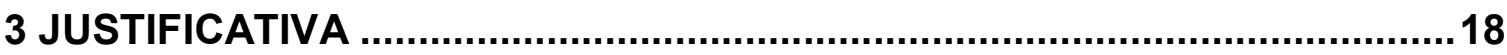

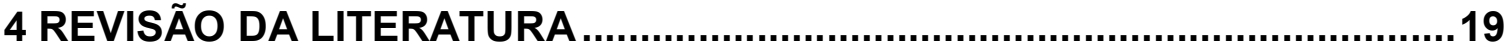

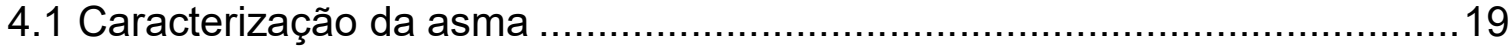

4.1.1 Definição ..................................................................................... 19

4.1.2 Etiopatogenia e fisiopatologia .................................................. 20

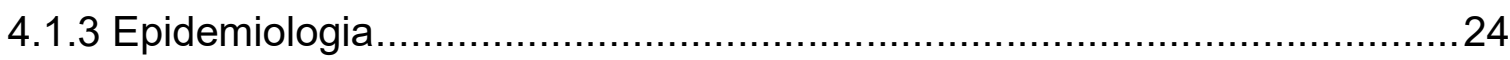

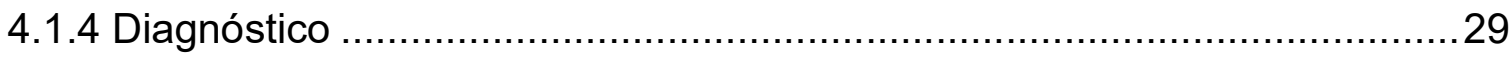

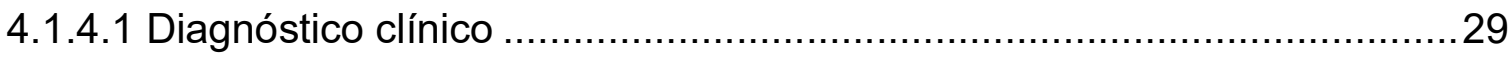

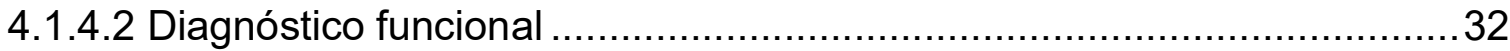

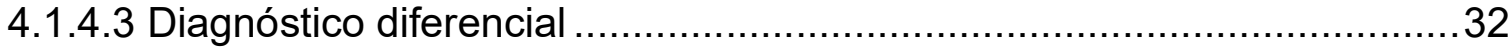

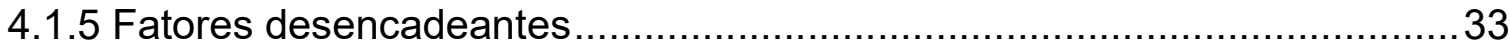

4.1.6 Condições agravantes da asma ................................................ 34

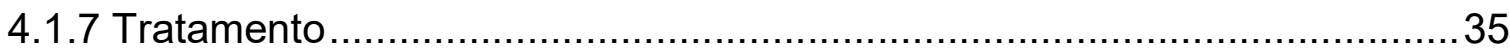

4.1.7.1 Tratamento para o controle da asma .......................................... 35

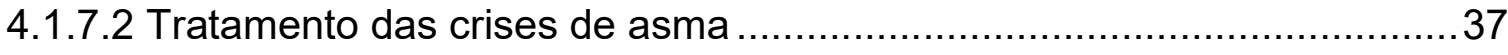

4.1.7.3 Abordagem das comorbidades ................................................. 40

4.1.7.4 Educação ambiental............................................................. 40

4.1.7.5 Parceria médico, paciente e familiares............................................. 41

4.2 Programas de controle da asma .................................................. 41

4.2.1 Programas de controle da asma no mundo ..................................... 42

4.2.2 Programas no Brasil................................................................ 46

4.2.3 Programa de Asma de Ipatinga - Programa Respirar ............................51

4.3 Radiação ionizante e a asma ............................................................... 57

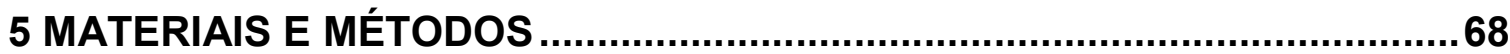




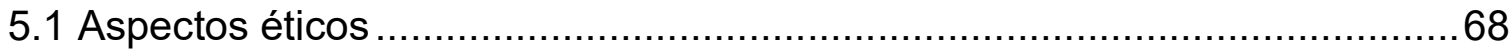

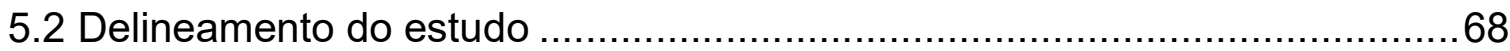

5.3 Obtenção de dados e instrumentos ............................................... 69

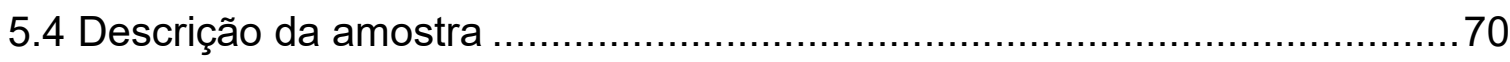

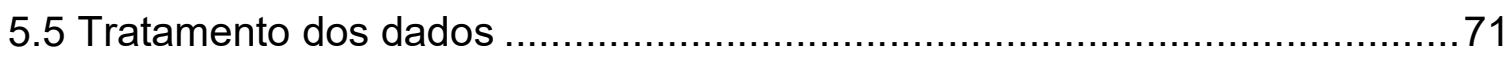

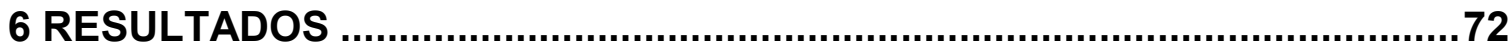

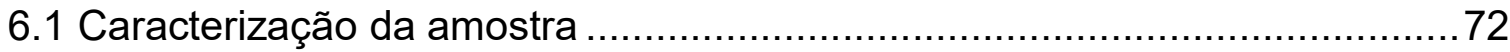

6.2 Comparação dos exames realizados entre casos e controles ....................73

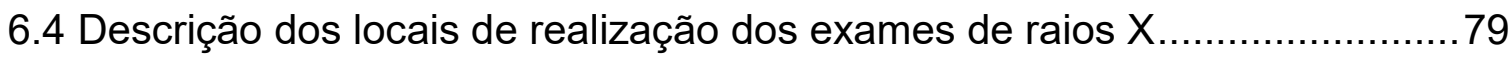

7 DISCUSSÃO .......................................................................................... 80

8 CONCLUSÕES E CONSIDERAÇÕES FINAIS ......................................... 84

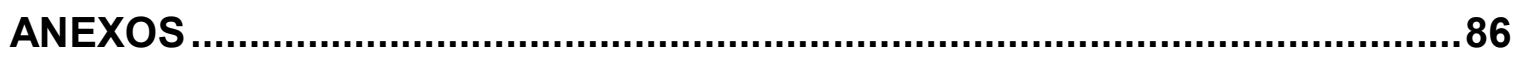

ANEXO A - Fórmula utilizada para o cálculo amostral .....................................86

ANEXO B - Resultados do teste de normalidade para as variáveis numéricas ..87

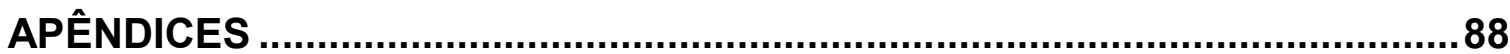

APÊNDICE A - Formulário de coleta de dados ............................................88

APÊNDICE B - Termo de Consentimento Livre e Esclarecido............................89

REFERÊNCIAS BIBLIOGRÁFICAS ........................................................91 


\section{LISTA DE TABELAS}

Página

TABELA 1 - Distribuição do número de pacientes por US e equipe ...................70

TABELA 2 - Caracterização dos dados sociodemográficos ...............................73

TABELA 3 - Comparação dos exames realizados em 2014 ................................75

TABELA 4 - Descrição do número de exames de raios $X$ realizados por grupo entre crianças e adolescentes de Ipatinga, no ano de 2014 ...................76

TABELA 5 - Correlação entre o número de raios $X(R X)$ realizados e a idade ou o tempo no Programa Respirar ................................................... 77

TABELA 6 - Descrição do número de exames de raios $X(R X)$ realizados de forma categorizada por grupo entre crianças e adolescentes de Ipatinga, no ano de 2014 .77

TABELA 7 - Comparação do número de exames de raios $X(R X)$ categorizados e a faixa etária ou o tempo no Programa Respirar na amostra de crianças e adolescentes do grupo respirar .78 


\section{LISTA DE QUADROS}

Página

QUADRO 1 - Índice clínico para o diagnóstico da asma em menores de três anos .31

QUADRO 2 - Classificação da asma, baseada em seu controle ...........................31

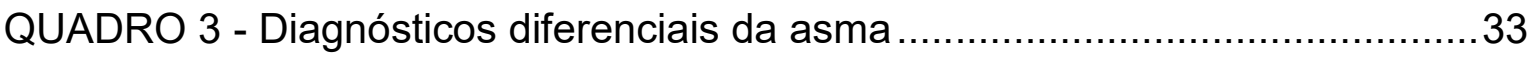

QUADRO 4 - Classificação da intensidade da crise asmática .................................38

QUADRO 5 - Etapas de tratamento da crise asmática .........................................39

QUADRO 6 - Indicações de exames complementares na crise asmática .............40 


\section{LISTA DE FIGURAS}

Página

FIGURA 1 - Comparação entre o brônquio normal e na asma. .20

FIGURA 2 - Fases da Resposta IgE-mediada (Abbas \& Lichtman, Celular and molecular immunology, 2005). .23

FIGURA 3 - Prevalência da asma no mundo .25

FIGURA 4 - Efeitos do controle da asma .35

FIGURA 5 - Manejo da asma baseado no nível de controle .36

FIGURA 6 - Objetivos do controle da asma .37

FIGURA 7 - Slogan da asma. 41

FIGURA 8 - Programas de Asma no Brasil. .50

FIGURA 9 - Mapa aglomerado urbano do Vale do Aço (AUVA). .51

FIGURA 10 - Localização de Ipatinga. .52

FIGURA 11 - Comparação da prevalência da asma no Brasil, Minas Gerais e Ipatinga entre os anos 2000-2012 .54

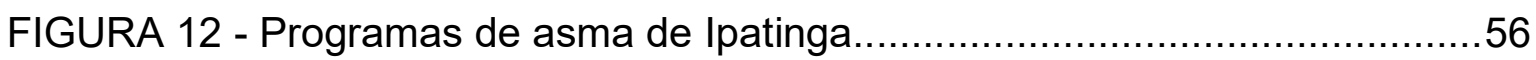

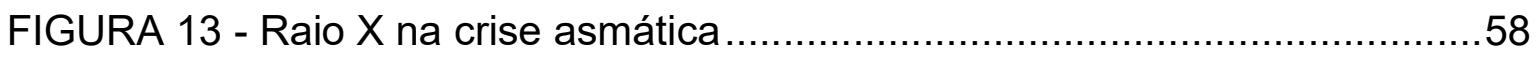

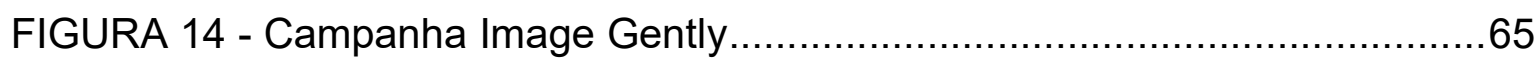

FIGURA 15 - Distribuição do número de raios $X$ realizados por grupo ..................76

FIGURA 16 - Gráfico de setores da distribuição do local de realização dos exames de raios $\mathrm{X}$ por grupo. 


\section{LISTA DE SIGLAS}

AAS Ácido Acetilsalicílico

ABRA Associação Brasileira de Asmáticos

ALARA As Low As Reasonably Achievable (tão baixo quanto razoavelmente exequível)

AINH Anti-inflamatórios não hormonais

ASBAI Associação Brasileira de Alergia e Imunopatologia

DATASUS Departamento de Informática do Sistema Único de Saúde do Brasil

DRGE Doença do Refluxo Gastroesofagiano

GINA Global Initiative for Asthma

IBGE Instituto Brasileiro de Geografia e Estatística

HRCT Tomografia Computadorizada de Alta Resolução

ICRP Comitê Internacional de Proteção Radiológica

IDH Índice de Desenvolvimento Humano

ISAAC International Study for Asthma and Allergies in Childhood

IVAS Infecção das Vias Aéreas Superiores

LABAS Broncodilatadores de Longa Duração

MS Ministério da Saúde

OMS Organização Mundial da Saúde

PAL Abordagem Prática para Doenças Pulmonares

PFE Pico de Fluxo Expiratório

PNCA Plano Nacional de Controle da Asma

PSM Pronto Socorro Municipal

RMVA Região Metropolitana do Vale do Aço

SBMFC Sociedade Brasieira de Medicina de Família e Comunidade

SBP Sociedade Brasileira de Pediatria

SBPT Sociedade Brasileira de Pneumologia e Tisiologia

SIAB Sistema de Informações de Atenção Básica

SMSA Secretaria Municipal de Saúde e Assistência 
SMS Secretaria Municipal de Saúde

SSP Serviço de Saúde Pública

SUS Sistema Único de Saúde

TCLE Termo de Consentimento Livre Esclarecido

UFMG Universidade Federal de Minas Gerais

US Unidade de Saúde

VRS Vírus Respiratorio Sincicial 


\section{INTRODUÇÃO}

Asma é uma doença de elevada prevalência e morbidade, reconhecida como um importante problema de saúde pública em todo o mundo. É uma doença inflamatória crônica, a inflamação brônquica caracteriza seu fator patogênico mais importante e há participação de muitos elementos celulares (Fontes et al., 2013). Existe uma associação entre inflamação crônica com hiper-responsividade de vias aéreas, que gera episódios recorrentes de sibilos, falta de ar, aperto no peito e tosse, especialmente à noite ou logo pela manhã (Oliveira et al., 2003).

A asma acomete cerca de 300 milhões de indivíduos em todo o mundo (Global Iniciative for Asthma - GINA, 2016) e no ano de 2050 esse número poderá ultrapassar os 100 milhões, totalizando 400 milhões de pessoas (Bąk-Walczak et al., 2011). Dados epidemiológicos obtidos no International Study for Asthma and Allergies in Childhood - ISAAC (ISAAC, 2011) mostram grande variabilidade na prevalência da asma, rinite alérgica, eczema e outras doenças respiratórias entre as crianças em diferentes países. Estima-se que no Brasil existam cerca de 20 milhões de asmáticos, se for considerada uma prevalência global de 10\% (Solé et al., 2006; Solé et al., 2007).

Segundo Kliegman et al. (2007), a asma é uma doença respiratória crônica que afeta pessoas de todas as idades.

De acordo com ISAAC (2011), a asma é uma doença que acomete cerca de $10 \%$ a $25 \%$ da população brasileira, sendo responsável, anualmente, por 400 mil internações hospitalares, segundo o Departamento de Informática do Sistema Único de Saúde do Brasil (DATASUS), em 2014, e 2.500 óbitos, além de um número incontável de atendimentos ambulatoriais, principalmente em salas de urgência, e implicando faltas ao trabalho e à escola (Kashiwabara; Rocha; Serqueira, 2016).

A asma é a quarta maior causa de hospitalização no Brasil, o que equivale ao terceiro maior gasto do Sistema Único de Saúde (SUS) com uma doença específica. Os custos da doença podem ser divididos em três tipos: os 
custos diretos (aqueles que podem ser calculados, como médicos, serviços de ambulância, cuidados domésticos, medicamentos e hospitalizações), os indiretos (relacionados às faltas ao trabalho, direitos previdenciários, faltas escolares, redução de produtividade) e os incalculáveis (o sofrimento humano, do paciente e da família). A maneira mais eficaz de reduzir os custos da asma é controlar a doença por meio de diagnóstico e tratamentos adequados para evitar crises e internações, sendo fundamental buscar orientação médica e seguir o tratamento prescrito (Solé, 2005).

A elevada prevalência da asma brônquica ressalta a necessidade de implantação de programa de assistência aos asmáticos, principalmente considerando que $15 \%$ deles apresentam sintomas persistentes que requerem tratamento de manutenção a longo prazo (Alvim et al., 2009).

A avaliação de um paciente com suspeita de asma fundamenta-se em uma anamnese completa, incluindo um histórico ambiental detalhado, com a descrição dos potenciais desencadeantes das crises (Telles Filho, 2017), e a maioria dos especialistas em asma acredita que a história do paciente representa a parte mais importante da avaliação.

Os pacientes com asma frequentemente são submetidos a procedimentos radiológicos, principalmente nas exacerbações, para esclarecimento diagnóstico das comorbidades e complicações, preferencialmente o raio $X$ de tórax (Shepherd, 2010). Muitas vezes este exame é realizado sem indicação evidente e com tendências ao aumento devido ao maior acesso e disponibilidade, com exposição à radiação ionizante e seus riscos, e muitas vezes contrariando os princípios do cuidado com a saúde infantil no que diz respeito à redução inteligente do uso da radiação em pacientes, especialmente pediátricos, conforme os preceitos As Low As Reasonably Achievable (ALARA).

$A$ escassez de dados na literatura referente aos riscos da exposição à radiação ionizante em pacientes com asma, especialmente crianças, e os possíveis benefícios relacionados à oportunidade de coleta de informações justificaram a investigação no programa municipal infantil de controle da asma de Ipatinga, Minas Gerais (Programa Respirar).

Foi estudado o risco de os pacientes deste programa receberem radiação ionizante por exames complementares em relação à população sem 
evidências de doenças crônicas, como forma de avaliar a eficácia do controle da doença e adequação das equipes às orientações do protocolo de atuação médica (diretrizes locais baseadas nas práticas internacionais vigentes e atuais), além do atendimento aos princípios As Low As Reasonably Achievable (ALARA) ou tão baixo quanto razoavelmente exequível. 


\section{OBJETIVOS}

\subsection{Objetivo geral}

Avaliar se os pacientes que participam de programa de prevenção da asma, com boa adesão ao plano de tratamento e com melhor controle de sua doença, apresentam risco equivalente de exposição à radiação ionizante, quando comparados à população normal.

\subsection{Objetivos específicos}

- Avaliar a eficácia do controle da doença;

- Avaliar a adequação das equipes em relação ao protocolo do Programa Respirar;

- Avaliar o atendimento aos princípios ALARA;

- Contribuir para estudo e pesquisa da asma. 


\section{JUSTIFICATIVA}

A justificativa norteadora para o desenvolvimento deste estudo teve como base evidências científicas descritas abaixo:

- Há evidências de solicitação desnecessária de raios X na asma, conforme Cerci Neto (2007).

- Demonstrou-se, em vários estudos, a tendência ao aumento da realização do exame por facilidade de acesso (Knapps; Simon; Sharma, 2013).

- Existe escassez de dados na literatura referentes aos riscos de exposição à radiação ionizante em pacientes de programas de controle da asma.

- Vários estudos demonstraram a redução de internações e idas à urgência em pacientes de programa específico de controle da asma (Fontes at al, 2013).

- Há constatações de que crianças são mais vulneráveis aos efeitos biológicos da radiação ionizante, pois há expectativa de vida longa, na qual pode haver risco potencial de se manifestar câncer induzido por radiação (Fresh, 2013; Buckmaster; Boon, 2005). 


\section{REVISÃO DA LITERATURA}

Neste segmento foram abordados, em maior profundidade, os termos ou palavras chaves que norteiam toda a problemática em estudo. Para a compreensão do tema discutimos a asma, uma doença muito prevalente em todo o mundo. Revisamos o conceito, etiologia, patogenia e fisiopatologia, epidemiologia, diagnóstico e tratamento, além dos programas de prevenção e tratamento da asma no mundo, no Brasil e em Ipatinga. Dando continuidade, realizamos a correlação da doença com a radiação ionizante e seus riscos.

\subsection{Caracterização da asma}

\subsubsection{Definição}

Asma é uma doença inflamatória crônica das vias aéreas e a inflamação brônquica representa seu fator patogênico mais importante. A intensidade do processo inflamatório do brônquio correlaciona-se com sua reatividade e com a expressão clínica da doença, como sibilos, dispneia, opressão torácica e tosse, principalmente à noite ou início da manhã (Fontes et al., 2013). Esses episódios são uma consequência da obstrução do fluxo aéreo intrapulmonar generalizado e variável, reversível espontaneamente ou com tratamento. A inflamação crônica ocasiona um ciclo contínuo de agressão e reparo que pode levar a alterações estruturais irreversíveis, isto é, o remodelamento das vias aéreas (GINA, 2016).

A última revisão do consenso GINA, no ano de 2016, define a asma enfatizando a heterogeneidade da doença e seus fenótipos.

A asma resulta de uma interação entre genética, exposição ambiental a alérgenos e irritantes, bem como outros fatores específicos que levam ao desenvolvimento e manutenção dos sintomas (Lemanske; Busse, 2003; Cookson, 1999).

De acordo com as diretrizes da Sociedade Brasileira de Pneumologia e Tisiologia para o manejo da asma, a principal característica fisiopatogênica da 
doença é a inflamação brônquica, resultante de interações entre células inflamatórias, mediadores e células estruturais das vias aéreas presentes em todos os pacientes asmáticos, inclusive naqueles de início recente, nas formas leves e mesmo entre os assintomáticos (SBPT, 2012).

Outro aspecto importante que deve ser incluído nesta definição diz respeito às alterações anatomofuncionais das vias aéreas inferiores, que em conjunto são nomeadas por remodelamento brônquico e que estão diretamente relacionadas à inflamação crônica da via aérea e ao prognóstico da doença (Silva, 2008; Campos, 2007).

Entre os fatores de risco para a asma têm-se os ambientais e aqueles próprios do paciente, como é o caso dos aspectos genéticos, obesidade e sexo masculino (durante a infância). Já entre os fatores ambientais são consideradas a exposição à poeira domiciliar e ocupacional, baratas, infecções virais, especialmente pelo vírus sincicial respiratório e rinovírus (Brasil, 2010).

A figura 1 ilustra as alterações brônquicas na asma.

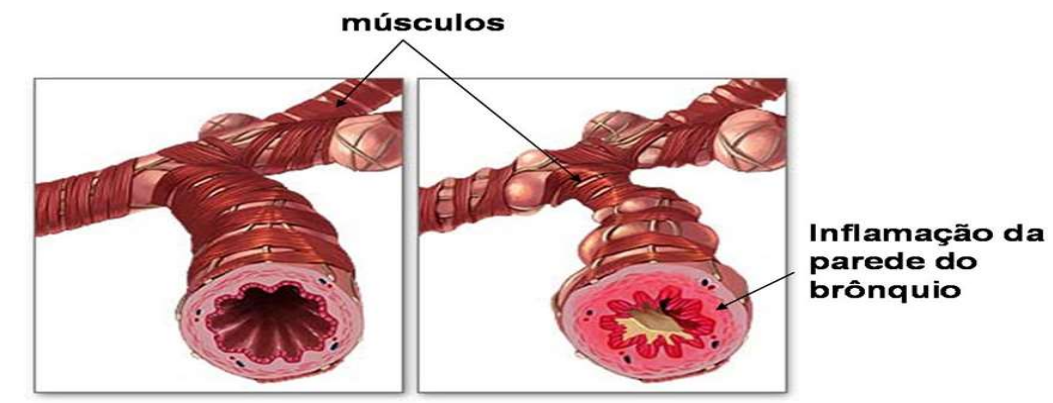

Brônquio normal (à esquerda) e na asma (à direita)

FIGURA 1 - Comparação entre o brônquio normal e na asma Fonte: Ramos, s/d

\subsubsection{Etiopatogenia e fisiopatologia}

Os mecanismos fisiopatológicos implicados no comprometimento da mecânica pulmonar são secundários a uma série de eventos que se encontram interligados como um mecanismo de cascata (Piva, 2015).

Fator importante entre os mecanismos fisiopatológicos da asma é representado pela resposta inflamatória, que envolve a participação de células do infiltrado inflamatório, de mediadores químicos e das células que revestem as vias aéreas. A inflamação está presente em todas as formas clínicas da asma, até mesmo entre os assintomáticos. A mucosa dos brônquios torna-se hiper-reativa a 
diversos estímulos, sejam eles alérgenos ou não, em resposta ao processo inflamatório (Silva, 2008).

O broncoespasmo, o edema de mucosa e a hipersecreção que se desenvolvem na crise aguda de asma promovem um aumento exagerado na resistência ao fluxo aéreo e que é potencializado, especialmente em crianças menores de cinco anos, pelo diminuto calibre de suas vias aéreas inferiores (Piva, 2015).

A asma brônquica se relaciona a um conjunto de diferentes fatores classificados como ambientais, ocupacionais e individuais (genéticos). Entre os fatores ambientais ou externos destacam-se os alérgenos inaláveis, tais como as substâncias do corpo e fezes de ácaros, antígenos de fungos, insetos e de animais domésticos, grãos de pólen, além dos vírus respiratórios, como o vírus sincicial respiratório (VSR) nos primeiros anos de vida. Outros poluentes ambientais agem como alérgenos indutores de hiper-responsividade brônquica em indivíduos sensíveis, tais como a fumaça de cigarro, poluentes particulados em suspensão no ar e partículas provenientes da queima do óleo diesel. Aproximadamente 300 substâncias são consideradas como agentes causais em potencial de asma ocupacional (Silva, 2008).

$\mathrm{Na}$ maioria das vezes, a asma é de fundo alérgico, envolvendo, portanto, a resposta mediada por IgE, que pode ser imediata ou tardia, caracterizando a inflamação crônica da doença (Silva, 2008; Kawakami; Kashiwakura; Kawakami, 2014).

A resposta alérgica relacionada à asma tem início quando indivíduos atópicos, que apresentam disposição genética para a produção de grandes quantidades de anticorpos lgE específicos contra quaisquer tipos de alérgenos ambientais/inaláveis, após serem sensibilizados, ou seja, produzirem $\lg \mathrm{E}$ específica para um ou mais desses alérgenos, disparam uma resposta de hipersensibilidade imediata (mediada por lgE) envolvendo células da mucosa brônquica. A ligação do complexo alérgenos/lgE à membrana dos mastócitos, que são tipos celulares presentes na mucosa e submucosa brônquica, induz a degranulação desses tipos celulares, liberando mediadores inflamatórios, como a histamina, o fator ativador de plaquetas (PAF), prostaglandinas e leucotrienos. Como resposta a tais mediadores, ocorre vasodilatação e extravasamento 
vascular, o que promove edema da parede brônquica, hipersecreção de muco e broncoconstrição, explicando o quadro clínico das crises de asma (Silva, 2008; Rivera et al., 2008).

Outros produtos liberados por mastócitos ativados são as interleucinas, além do fator estimulador de crescimento de granulócitos e monócitos que, aliados aos leucotrienos, são quimiotáticos, além de ativarem outras células da resposta inflamatória na parede brônquica, perpetuando o processo inflamatório local. Dessa maneira, a inflamação brônquica da asma apresenta outras características, além da ativação e degranulação de mastócitos, como a infiltração eosinofílica, a lesão intersticial e epitelial das vias aéreas e a ativação de linfócitos Th2 que são responsáveis pela produção de citocinas, que atuam amplificando e agravando o processo inflamatório (Kalesnikoff; Galli, 2008).

$\mathrm{Na}$ fase crônica da doença, graças à ação das células epiteliais e dos miofibroblastos, ocorrerá deposição intersticial de colágeno e proteoglicanos na lâmina reticular da membrana basal, induzindo o espessamento e as lesões irreversíveis nos casos de asma grave ou de longa evolução. Outras alterações marcam o remodelamento das vias aéreas, como a hipertrofia e hiperplasia do músculo liso, a elevação no número de células caliciformes, o aumento das glândulas e vasos sanguíneos submucosos e a alteração no depósito/degradação dos componentes da matriz extracelular e que se relacionam à irreversibilidade da obstrução brônquica nos casos graves da doença. Essas alterações anatomopatológicas, que se acreditava anteriormente ocorrerem somente nos indivíduos com asma grave, podem ser observadas nas formas mais leves da doença e até mesmo em crianças. Dessa forma, a fibrose subepitelial está presente em todos os indivíduos com asma, mesmo antes do surgimento de sintomas (Sircar et al., 2014). A reação inflamatória pode levar a alterações estruturais persistentes das vias aéreas, o remodelamento brônquico, explicando a refratariedade clínica e alteração persistente da função pulmonar, apesar da terapêutica adequada (Silva, 2008).

A figura 2 representa alguns dos mecanismos da inflamação na asma. 


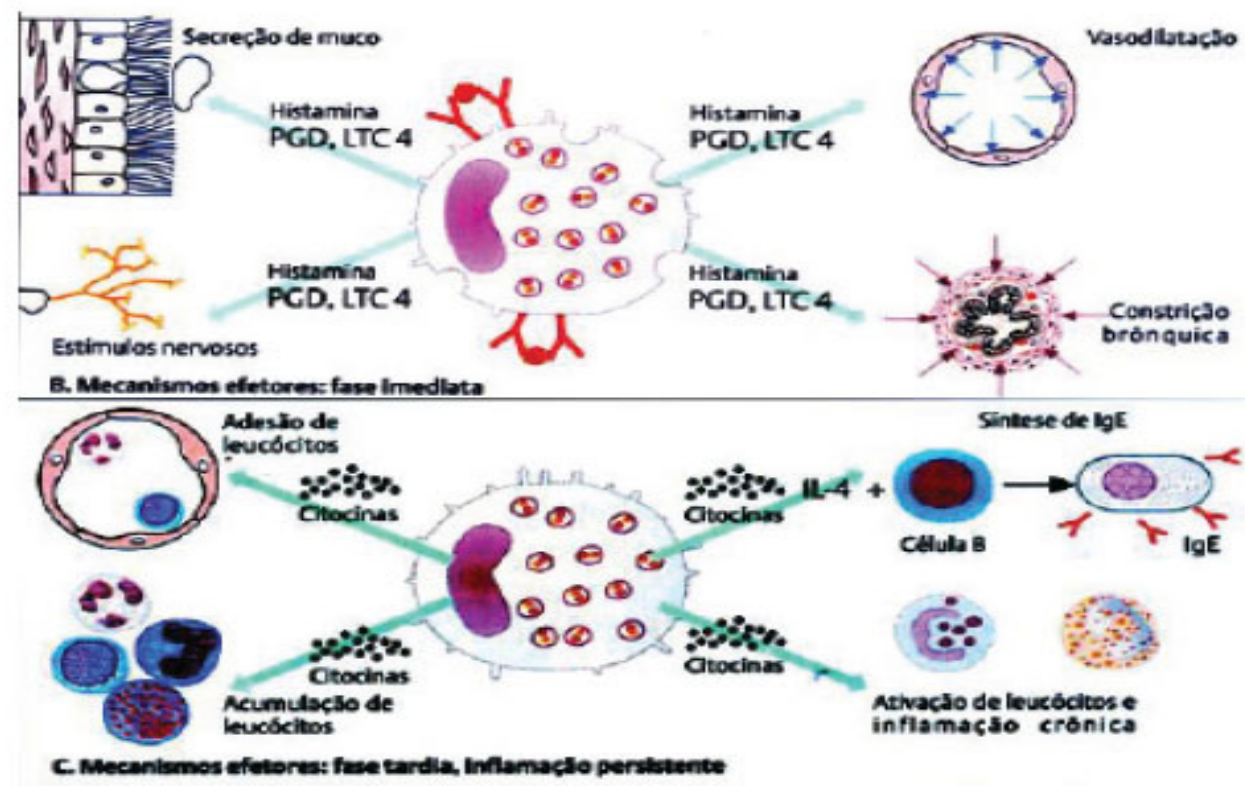

FIGURA 2 - Fases da Resposta IgE-mediada (Abbas \& Lichtman, Celular and molecular immunology, 2005)

Fonte: Silva, 2008

Infecções virais do trato respiratório alto ou baixo são o principal fator desencadeante de crises, tanto em adultos quanto em crianças. Os vírus respiratórios têm a capacidade de aumentar consideravelmente a hiperresponsividade brônquica, ao estimularem o processo inflamatório. Além disso, o atópico apresenta maior facilidade em contrair infecções virais respiratórias, particularmente pelo rinovírus. Desta forma, os vírus podem ser importantes fatores de aumento e manutenção da inflamação brônquica e de agravamento da doença, particularmente em crianças (Silva, 2008).

Características individuais também estão associadas ao desenvolvimento de asma. Crianças do sexo masculino têm risco duas vezes superior de desenvolver asma em comparação com meninas da mesma idade. A obesidade também tem sido associada ao maior risco de asma (Silva, 2008)

A hipótese da higiene é uma das explicações para o aumento da prevalência da asma. A melhora da higiene ambiental atenua a exposição a bactérias e parasitas, levando à diminuição de condições que induzem estímulos de citocinas Th1, com consequente desequilíbrio entre Th1 e Th2, com prevalência de Th2 (atópico) (Fontes et al., 2013). 


\subsubsection{Epidemiologia}

A asma pode ter início em qualquer idade, com predomínio na infância e adolescência (Silva, 2008).

A asma e as doenças alérgicas são as principais causas de adoecimento em crianças e estão aumentando progressivamente (Bateman; Jithoo, 2007; Pearce et al., 2007).

Há várias décadas, estudos epidemiológicos e de vigilância apontam o aumento da prevalência de asma no mundo inteiro (Bousquet et al., 2007; Farrar, 2005).

Alguns estudos evidenciam aumento da morbidade associado à diminuição da mortalidade pela asma em países industrializados (Bousquet et al., 2007; Masoli et al., 2004; Abramson et al., 2001).

Aparentemente, a prevalência da asma está aumentando tanto nos países desenvolvidos como naqueles em desenvolvimento, afetando pessoas de todas as idades, raças e grupos étnicos. As estimativas do Global Initiative for Asthma da Organização Mundial da Saúde (OMS) são de que 300 milhões de pessoas em todo o mundo sofrem desta patologia. Sua prevalência é variada, entre $1 \%$ e $18 \%$ da população em diferentes países. Há evidências de que venha aumentando em certos países, de que tenha aumentado recentemente em outros e de que, no presente, esteja estabilizada em alguns outros. Com a projeção de que a proporção da população mundial urbana passará de $45 \%$ para $59 \%$ em 2025, tudo indica que o número de asmáticos aumentará nas próximas duas décadas. Assim, estima-se que mais 100 milhões de pessoas serão asmáticas em 2025 (Masoli et al., 2004).

Segundo as estimativas da OMS, a asma causa cerca de $250 \mathrm{mil}$ mortes anualmente em todo o mundo, o que representa 1:250 morte.

A figura 3 representa a prevalência da doença no mundo. 


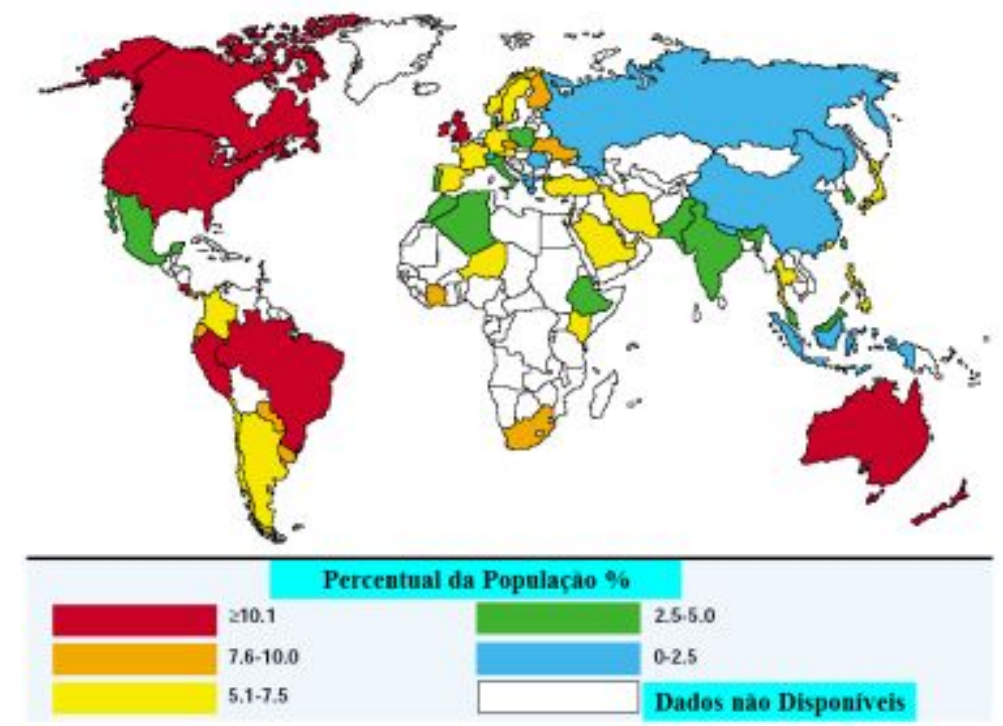

FIGURA 3 - Prevalência da asma no mundo Fonte: GINA, 2016

O International Study for Asthma and Allergies in Childhood (ISAAC) foi idealizado para maximizar o valor dos estudos epidemiológicos em asma e doenças alérgicas, estabelecendo método padronizado capaz de facilitar a colaboração internacional. Realizado em três fases sucessivas e dependentes, 0 ISAAC reuniu uma casuística até então inimaginável no mundo e no Brasil (Solé et al., 2014).

Dados epidemiológicos obtidos pelo ISAAC mostram grande variabilidade na prevalência da asma, rinite alérgica, eczema e outras doenças respiratórias entre as crianças, em diferentes países. De acordo com o ISAAC, a asma é uma doença que acomete cerca de 24,3\% (oscilando de 16,5 a 31,2\%) das crianças e de 19\% (oscilando de 11,8 e 30,5\%) dos adolescentes brasileiros, sem relação com o nível socioeconômico (Solé et al., 2014).

A primeira fase do ISAAC (1996), concluído no Brasil, foi um verdadeiro divisor de águas no conhecimento da prevalência de asma e das doenças alérgicas no país. Antes, os dados epidemiológicos brasileiros disponíveis eram restritos a amostras populacionais pequenas, principalmente de grandes centros urbanos e instituições educacionais, sem qualquer padronização na sua obtenção, o que dificultava muito a sua comparação. A compilação dos dados mundiais reuniu, pela primeira vez, número expressivo de crianças (seis - sete anos) e de adolescentes (13-14 anos) jamais avaliado anteriormente e mostrou 
grande variabilidade nas taxas observadas entre os diferentes centros avaliados. No Brasil, participaram da primeira fase do ISAAC sete centros que viabilizaram a obtenção, pela primeira vez, de dados confiáveis sobre a prevalência de asma, rinite alérgica e eczema atópico em crianças e adolescentes. A análise comparativa com todos os dados mundiais obtidos mostrou ser elevada a prevalência média de asma nas crianças $(23,3 \%)$ e nos adolescentes $(22,7 \%)$, encontrando que os países de idioma inglês e a América Latina ocupam a oitava posição entre os centros de maior prevalência. Os poucos centros envolvidos na segunda fase investigaram possíveis fatores etiológicos, especialmente aqueles sugeridos pelos resultados da primeira fase, e geraram muitas especulações. A terceira fase, repetida após sete anos, avaliou a tendência evolutiva da prevalência de asma e das doenças alérgicas nos centros participantes simultaneamente das fases I e II e determinou a prevalência em outros não envolvidos na fase I (Solé et al., 2014).

A elevada prevalência da asma brônquica ressalta a necessidade de implantação de programa de assistência aos adolescentes asmáticos, principalmente considerando que $15 \%$ deles apresentam sintomas persistentes que requerem tratamento de manutenção a longo prazo, segundo Alvim et al. (2009). Solé et al. (2014) afirmam que, no Brasil, o ISAAC demonstrou, de forma definitiva, que a asma é uma doença de alta prevalência, devendo ser encarada como problema de saúde pública.

Jucá et al. (2012) desenvolveram estudo sobre a prevalência de asma ativa e os fatores associados a ela em adolescentes de 13 a 14 anos em Cuiabá, Mato Grosso, Brasil. Seus resultados registraram que, apesar da prevalência da asma ativa ter sido alta e igual a 19,1\%, houve uma redução significativa em relação a 1998. Como fatores de risco associados à asma ativa encontraram: fumar durante a gravidez, aleitamento materno exclusivo menor que seis meses, renda familiar menor que três salários mínimos, ser do gênero feminino, ter animais de estimação em casa e ausência de peixes na dieta.

Estudo de prevalência realizado em Recife, Pernambuco, registrou a asma em 43\% das 1.071 crianças com idade inferior a um ano. Além disso, foi observado que a sibilância no primeiro ano de vida associou-se com pneumonia, história familiar de asma, mais de nove episódios de infecção das vias aéreas 
superiores e a primeira crise antes dos seis meses de idade (Medeiros et al., 2011).

Luna, Almeida e Silva (2011), ao desenvolverem estudo transversal com 3.015 adolescentes que viviam em Fortaleza, Ceará, observaram que a prevalência de asma era de 22,6\%; da rinite, 43,2\%; de 18,7\% para rinoconjuntivite e com predomínio entre as meninas.

Macedo et al. (2007) realizaram estudo de base populacional que envolveu 1.968 indivíduos com idade entre 20 e 69 anos em Pelotas, Rio Grande do Sul, e registraram prevalência de asma igual a $6 \%$, podendo variar de acordo com o critério de diagnóstico. Além disso, apontaram, como fator de risco, ser do sexo feminino, ter idade entre 60-69 anos, pele de cor não branca, baixa escolaridade, baixa renda familiar, história famíliar de atopia e asma, história pessoal de doença atópica, tabagismo, baixo índice de massa corporal e distúrbios psiquiátricos.

Segundo Kashiwabara (2016), ao considerar estudos relativos à prevalência de asma em diferentes municípios do estado de Santa Catarina, desenvolvidos por vários autores, observou que em Florianópolis, Itajaí e Criciúma a frequência de asma atual foi de 18,8\%, 12,5\% e 10,5\%, respectivamente, e em Tubarão e Capivari de Baixo foi de 11,8\%.

Wehrmeister et al. (2012) analisaram os dados de prevalência de asma da Pesquisa Nacional por Amostra de Domicílios no Brasil, dos anos de 1998, 2003 e 2008. Encontraram prevalência de asma entre as crianças de 7,7\% em 1998, 8,1\% em 2003 e 8,5\% em 2008, com um incremento anual de 1\%. O maior aumento anual foi observado nas regiões Sudeste e Norte $(1,4 \%)$. Entre o grupo de adolescentes, a prevalência de asma foi de 4,4\% em 1998, 5,0\% em 2003 e $5,5 \%$ em 2008, com aumento de 2,2\% ao ano. Na região Nordeste, o aumento anual na prevalência de asma foi de $3,5 \%$. Os maiores incrementos foram observados entre os meninos e entre moradores da zona rural.

Lima et al. (2012), por meio de um estudo transversal envolvendo crianças de 13 e 14 anos em São Luis, no Maranhão, no Nordeste do Brasil, concluíram que a prevalência de asma foi de 12,7\%; 3,9\% relataram dificuldade em falar devido à respiração ofegante e 9,8\% relataram chiado após o exercício. 
Anualmente ocorrem cerca de 350.000 internações por asma no Brasil, constituindo-se na quarta causa de hospitalizações pelo SUS (2,3\% do total) e sendo a terceira causa entre crianças e adultos jovens (Brasil, 2005; Moura et al. 2010; Carvalho; Souza; Souza, 2014). Ao analisarem as principais causas de internação sensíveis à atenção primária em pacientes menores de 20 anos, nas diferentes regiões brasileiras, observaram que, apesar de a asma estar sempre entre uma das principais causas em todas as faixas etárias consideradas, houve tendência ao declínio no período de 1999 a 2006.

Pode-se dizer que mais da metade da população de asmáticos, conforme estatística americana, esteve sujeita a visitas em salas de emergências hospitalares. Sob este ponto de vista, as crises agudas podem ser responsáveis por até $10 \%$ das admissões e 2 a $7 \%$ das internações em UTI pediátrica (Carvalho; Souza; Souza, 2014).

A mortalidade por asma é baixa, mas apresenta uma magnitude crescente em diversos países. Nos países em desenvolvimento, ela aumentou nas últimas décadas do século $X X$, correspondendo a até $10 \%$ das mortes por causa respiratória, com elevada proporção de óbitos domiciliares. Estudos isolados apontaram estabilização ou até mesmo redução da mortalidade por asma em algumas cidades de países desenvolvidos na Europa, o que pode estar associado ao melhor reconhecimento e consequente diagnóstico da doença, assim como ao uso mais difundido de medicamentos com efeito anti-inflamatório (corticosteroides tópicos), nos últimos anos (Silva, 2008).

Silva e Silva (2013) avaliaram a tendência das taxas de mortalidade relacionada à asma no município do Rio de Janeiro, Brasil, no período de 2000 a 2009, e observaram uma tendência de queda na taxa de mortalidade padronizada relacionada à asma como a causa básica ou associada de morte, com uma redução nos homens e estabilidade nas mulheres. Quando a asma é a causa subjacente, as mais comuns associadas foram as doenças do sistema respiratório.

Acredita-se que mais de 250.000 óbitos a cada ano, no mundo, se devam à asma, sendo a maioria deles evitável com o tratamento efetivo de controle. Há uma grande diferença nos índices de mortalidade entre os países que disponibilizam o tratamento de controle para a população em relação aos que 
não o fazem (Masoli et al., 2004). Nos países desenvolvidos, as taxas de mortalidade aumentaram gradativamente desde 1975, estabilizaram-se entre as décadas de 1980 e 1990 e, a partir daí, começaram a diminuir (Chatkin et al., 2007; Sturdy et al., 2005; Pearce et al., 2007).

A mortalidade por asma em crianças de zero a 19 anos de idade foi avaliada em um estudo ecológico feito por Prietsch et al. (2012), no período de 1980 a 2007 no Brasil, e apontou um decréscimo significativo em crianças divididas segundo grupos etários. Concluem, então, que a mortalidade por asma em crianças brasileiras é baixa e mantém a tendência de queda no período estudado em todas as faixas etárias pediátricas.

A asma tem, em todo o mundo, um grande impacto econômico, seja por custos diretos ou indiretos, e social, relacionado a perdas de dias de escola e trabalho, assim como ao sofrimento individual e familiar. Dados norte-americanos apontam para um custo total anual de mais de 6 bilhões de dólares associados a asma naquele país. O custo para o controle da asma é alto, mas certamente os custos do não tratamento da doença são muito maiores, tanto para o indivíduo quanto para o sistema de saúde (Silva, 2008).

\subsubsection{Diagnóstico}

O diagnóstico da asma brônquica baseia-se na história clínica e exame físico e, sempre que possível, na comprovação da obstrução do fluxo aéreo por meio da espirometria com prova broncodilatadora (GINA, 2016; Minas Gerais, 2007). O paciente deve ser avaliado também na intercrise. A abordagem diagnóstica depende da idade do paciente e precisa garantir sua avaliação integral (Fontes, 2013).

\subsubsection{Diagnóstico clínico}

O diagnóstico é realizado por meio da história recorrente de um ou mais sintomas: dispneia, tosse crônica, sibilância, opressão ou desconforto torácico, sobretudo à noite ou nas primeiras horas da manhã. Há maior suspeita do diagnóstico de asma quando existe variabilidade dos sintomas, desencadeamento por irritantes inespecíficos (como fumaças, odores fortes e exercício) ou por aeroalergenos (como ácaros e fungos), piora dos sintomas à 
noite e melhora espontânea ou após o uso de medicações específicas. A sintomatologia nos últimos 12 meses e pregressa, o impacto da doença, os sentimentos a ela relacionados e seu conhecimento adequado, passado mórbido, histórico da família, os cuidados implementados ao ambiente e a presença de sinais de manifestações atópicas devem ser cuidadosamente investigados, e outras causas de sibilância devem ser excluídas (GINA, 2016; SBPT, 2012).

$\mathrm{Na}$ maioria dos pacientes, para qualquer grau de asma, podem ocorrer sinais característicos, chamados de estigmas da atopia, como pregas palpebrais, "olheira alérgica", eczemátides e hiperceratose pilosa (King; Moores, 2008). Nos casos de asma grave e de longa duração, independentemente da idade do paciente, os sintomas se assemelham às alterações produzidas pela doença pulmonar obstrutiva crônica, como deformidade torácica devido à hiperinsuflação pulmonar crônica, aumento do diâmetro anteroposterior, diminuição da expansibilidade, hipertimpanismo na percussão e redução do murmúrio vesicular na ausculta do tórax. No momento das crises, e variando conforme o grau de gravidade, podemos observar ainda tosse seca ou com expectoração mucoide e viscosa (semelhante à clara de ovo), dispneia com prolongamento do tempo expiratório, uso de musculatura acessória da respiração, sibilos que na maioria das vezes são bilaterais e simétricos, roncos esparsos ou difusos. Nos casos mais graves, pode ocorrer cianose, além da agitação psicomotora secundária à hipoxemia, com redução dos sibilos que pode alcançar o "silêncio respiratório", torpor e coma, que resultam da fadiga respiratória e consequente hipercapnia (Tregoning; Schwarze, 2010; Silva, 2008).

Asma é doença heterogênea, com diferentes processos obscuros da doença. Asma alérgica é reconhecida mais facilmente (GINA, 2016).

No diagnóstico da asma em lactentes e crianças menores, deve-se estar atento aos seguintes sintomas: a ocorrência de três ou mais episódios de sibilância no último ano, principalmente se houver história de asma materna, eczema e se os episódios não ocorrem apenas em associação com infecção de via aérea superior (IVAS) (Lemanske; Busse, 2010).

A asma é mais dificilmente diagnosticada nos lactentes, e pode-se servir do índice clínico para melhor definir a probabilidade da doença (quadro 1). O diagnóstico deve basear-se em aspectos clínicos devido às dificuldades de se 
obter medidas objetivas nesta faixa etária (SBPT, 2012). A sibilância tem elevada prevalência na primeira infância, e a maioria não tem asma. Reconhecer os fenótipos, os critérios de maior suspeita da doença e diagnóstico alternativo é fundamental na decisão terapêutica. Dois sinais maiores ou um sinal maior e dois menores aumentam a chance de o quadro respiratório ocorrer por asma, mas o acompanhamento é que definirá o diagnóstico (Fontes et al., 2013).

QUADRO 1 - Índice clínico para o diagnóstico da asma em menores de três anos

\begin{tabular}{|l|l|}
\hline \multicolumn{1}{|c|}{ Critérios maiores } & \multicolumn{1}{c|}{ Critérios menores } \\
\hline História familiar (pai e/ou mãe) de asma & Rinite alérgica \\
Dermatite atópica ou eczema & Sibilos não apenas associados a resfriados \\
& Eosinófilos > = 4\% (Hemograma) \\
\hline
\end{tabular}

Fonte: Castro-Rodriguez et al., 2000

Não é apropriado confundir gravidade com o grau de controle da asma, pois podemos encontrar um asmático grave bem controlado e um asmático leve não controlado (Cockcroft; Swystun, 1996).

Estabelecer a gravidade é importante para o ajuste inicial do tratamento, sendo esta classificada conforme seu controle.

Os critérios a serem considerados para a classificação da asma estão registrados no quadro 2 e consideram o controle da doença.

QUADRO 2 - Classificação da asma, baseada em seu controle

\begin{tabular}{|c|c|c|c|}
\hline \multicolumn{4}{|c|}{$\begin{array}{c}\text { Avaliação controle clínico atual } \\
\text { (preferencialmente nas últimas quatro semanas) }\end{array}$} \\
\hline Parâmetros & Asma controlada & $\begin{array}{c}\text { Asma parcialmente } \\
\text { controlada }\end{array}$ & $\begin{array}{c}\text { Asma não } \\
\text { controlada }\end{array}$ \\
\hline parâmetros abaixo & $\begin{array}{c}\text { Um ou dois dos } \\
\text { parâmetros abaixo }\end{array}$ & $\begin{array}{c}\text { Três ou mais dos } \\
\text { parâmetros da } \\
\text { asma parcialmente } \\
\text { controlada }\end{array}$ \\
\hline $\begin{array}{c}\text { Sintomas diurnos } \\
\text { Limitação de } \\
\text { atividades }\end{array}$ & $\begin{array}{c}\text { Nenhum ou } \leq 2 \text { por } \\
\text { semana }\end{array}$ & $\begin{array}{c}\text { Três ou mais por } \\
\text { semana }\end{array}$ & \\
\hline $\begin{array}{c}\text { Sintomas/despertares } \\
\text { noturnos }\end{array}$ & Nenhuma & Qualquer & \\
\hline $\begin{array}{c}\text { Necessidade de } \\
\text { medicação de alívio }\end{array}$ & $\begin{array}{c}\text { Nenhuma ou } \leq 2 \\
\text { por semana }\end{array}$ & $\begin{array}{c}\text { Três ou mais por } \\
\text { semana }\end{array}$ & \\
\hline $\begin{array}{c}\text { Função pulmonar } \\
(\text { PFE ou VEF })^{\text {b.c }}\end{array}$ & Normal & $\begin{array}{c}<80 \% \text { predito ou do } \\
\text { melhor prévio (se } \\
\text { conhecido) }\end{array}$ & \\
\hline
\end{tabular}


cont. QUADRO 2

Avaliação dos riscos futuros

(exacerbações, instabilidade, declínio acelerado da função pulmonar e efeitos diversos)

Características que estão associadas com aumento dos riscos de eventos adversos no futuro: mau controle clínico, exacerbações frequentes no último ano ${ }^{a}$, admissão prévia em UTI, baixo $\mathrm{VEF}_{1}$, exposição à fumaça do tabaco e necessidade de usar a medicação em altas dosagens.

${ }^{2}$ Por definição, uma exacerbação em qualquer semana é indicativa de asma não controlada. Qualquer exacerbação é indicativa da necessidade de revisão do tratamento de manutenção. "Valores prébroncodilatador sob o uso de medicação controladora atual. 'Não aplicável na avaliação do controle da asma em crianças menores de cinco anos.

Fonte: SBPT, 2012

Raio $X$ de tórax pode ser necessário para excluir outros diagnósticos. $A$ radiografia faz parte da propedêutica inicial de crianças com sibilância recorrente e deve preceder a corticoterapia contínua inalatória. Nela podem ser evidenciados, por exemplo, tumores mediastinais, áreas de hiperinsuflação localizada por mecanismo valvular (por exemplo, corpo estranho), atelectasias decorrentes de aspiração de corpo estranho, aumento da área cardíaca, algumas malformações pulmonares), conforme Fontes et al. (2013).

\subsubsection{Diagnóstico funcional}

O diagnóstico clínico da asma deve ser confirmado por um método objetivo, uma vez que os sinais e sintomas não são exclusivos desta condição (SBPT, 2012). Os testes diagnósticos disponíveis na prática clínica incluem espirometria (antes e após o uso de broncodilatador), testes de broncoprovocação e medidas seriadas de Pico de Fluxo Expiratório (PFE). Estes testes são realizados em pacientes acima de cinco anos, idade em que a criança consegue cumprir os procedimentos necessários para sua realização.

Em certos casos, a comprovação da reversibilidade da obstrução ao fluxo aéreo pode ser demonstrada apenas com o teste terapêutico com corticoide oral (SBPT, 2012).

\subsubsection{Diagnóstico diferencial}

"Nem tudo que sibila é asma." Assim, frente a uma criança com sibilância recorrente, uma consideração de ordem prática é assegurar que ela não apresenta diagnóstico alternativo (Fontes et al., 2013).

O quadro 3 apresenta as patologias mais comuns que devem ser descartadas. 
QUADRO 3 - Diagnósticos diferenciais da asma

- Rinossinusite

\section{Criancas menores de cinco anos de idade}

- Doença pulmonar crônica da prematuridade e malformações congênitas

- Fibrose cística, bronquiectasias, bronquiolite obliterante pós-infecciosa e discinesia ciliar

- Síndromes aspirativas (refluxo gastroesofágico, distúrbios de deglutição, fístula traqueoesofágica e aspiração de corpo estranho)

- Laringotraqueobroncomalácia, doenças congênitas da laringe (estenose e hemangioma) e anel vascular

- Tuberculose

- Cardiopatias

- Imunodeficiências

- Rinossinusite

\section{Criancas acima de cinco anos e adultos}

- Síndrome de hiperventilação alveolar e síndrome do pânico

- Obstrução de vias aéreas superiores (neoplasias e aspiração de corpo estranho)

- Disfunção das cordas vocais

- DPOC e outras doenças obstrutivas das vias aéreas inferiores (bronquiolites, bronquiectasias e fibrose cística)

- Doenças difusas do parênquima pulmonar

- Insuficiência cardíaca diastólica e sistólica

- Doenças da circulação pulmonar (hipertensão e embolia)

Fonte: SBPT, 2012

\subsubsection{Fatores desencadeantes}

As exacerbações ou crises asmáticas podem ser desencadeadas por diversos fatores, alérgicos e não alérgicos.

Dentre os específicos (alérgicos), destacam-se os alérgenos inaláveis, substâncias derivadas de ácaros domésticos, animais como cão e gato, baratas e fungos do ar. Na região Sul do Brasil, assim como no Hemisfério Norte, onde as estações climáticas são mais bem definidas e, por conseguinte, ocorre a polinização em determinadas épocas do ano, os polens também são importantes desencadeantes de sintomas (Silva, 2008).

Os fatores inespecíficos ou não alérgicos incluem as infecções virais (rinovírus, vírus sincicial respiratório, influenza e parainfluenza), que são a causa mais frequente de crise de asma em lactentes e crianças (até $90 \%$ das crises). Outros desencadeantes inespecíficos são as mudanças climáticas, o ar frio e seco, os poluentes ambientais, inclusive o tabaco, e cheiros fortes (detergentes, perfumes, tintas) (Silva, 2008).

Segundo Passos (2014), atualmente as alterações climáticas e a poluição ambiental estão associadas ao aumento da morbimortalidade por doenças respiratórias em crianças, com acréscimo significativo nos atendimentos de emergência em dias com taxas de poluição atmosférica mais elevada. 
Embora estudos recentes considerem a genética como importante fator de risco para as doenças alérgicas (Steinke; Rich; Boris, 2008), o ambiente também exerce influência significativa na sua ocorrência e progressão. Os fatores ambientais incluem a poluição atmosférica e os vários agentes domésticos (Dong et al., 2008).

O estilo de vida, incluindo a dieta na primeira infância, tem também relevância como agente predisponente para as doenças alérgicas (Kim; Ellwood; Asher, 2009; Pawlinska-Chmara et al., 2008).

Silva (2008) relaciona o exercício físico como desencadeante de crises de asma, muitas vezes manifestadas apenas por tosse seca e baixa tolerância ao esforço, principalmente em crianças e adolescentes. Estas alterações também podem acontecer eventualmente durante o riso. Raramente, alimentos podem desencadear crise de asma isolada. Em quadros de alergia alimentar, o broncoespasmo pode ocorrer associado a outras manifestações de anafilaxia, como urticária, angioedema e hipotensão arterial.

Cerca de $10 \%$ dos asmáticos apresentam sensibilidade ao ácido acetilsalicílico (AAS) e a anti-inflamatórios não hormonais (AINHs), que podem desencadear crises se usados por via sistêmica ou mesmo tópica. Os betabloqueadores podem desencadear broncoespasmo em pacientes com hiperresponsividade brônquica subclínica, ou ainda agravar a asma preexistente, e por isso são contraindicados nesses pacientes (Silva, 2008).

Ainda conforme Silva (2008), na prática clínica nunca se deve menosprezar a influência de fatores emocionais sobre as doenças crônicas e não é raro observar sua ação como desencadeantes ou, pelo menos em parte, como agravantes de crises de asma.

\subsubsection{Condições agravantes da asma}

Algumas condições clínicas podem estar associadas com a asma e contribuir para seu agravamento, aumentando a necessidade do uso de medicamentos. São elas a rinossinusopatia (aguda ou crônica), a doença do refluxo gastroesofágico (DRGE) e as micoses broncopulmonares alérgicas. Devem ser investigadas e tratadas quando houver sinais/sintomas de suspeição, 
ou quando a asma não responde ao tratamento de manutenção corretamente instituído (Silva, 2008).

\subsubsection{Tratamento}

\subsubsection{Tratamento para o controle da asma}

Por muitos anos, a eficácia das novas drogas para o tratamento da asma tem sido avaliada pela medida de seu impacto na gravidade e no controle da doença, por meio da espirometria e do pico de fluxo, gravidade dos sintomas, necessidade de outras medicações e análise da responsividade brônquica. Todos estes indicadores são importantes para determinar o efeito terapêutico no órgãoalvo, o "status" das vias aéreas (Piovesan et al., 2006),

O principal objetivo é o controle da inflamação, reduzindo sintomas e exacerbações, além de melhorar a função pulmonar e a qualidade de vida, como esquematizado na figura 4.

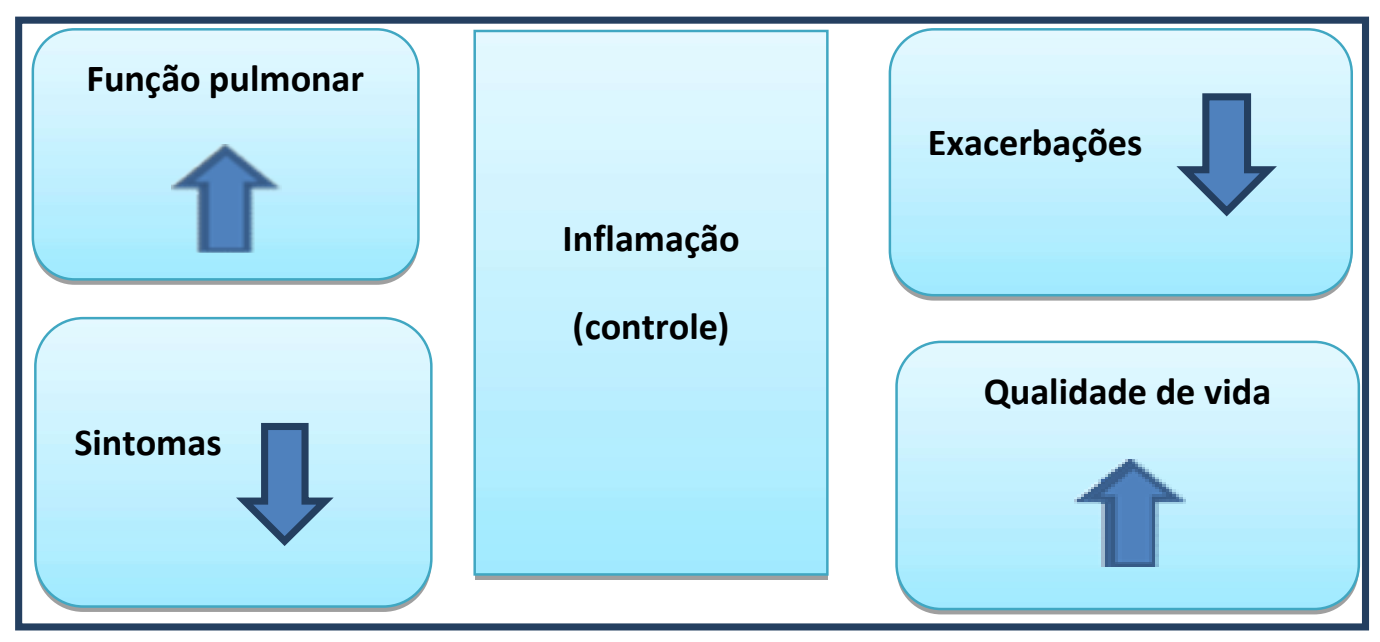

FIGURA 4 - Efeitos do controle da asma

Fonte: Dados do próprio autor

Os corticoides inalatórios disponíveis no Brasil e aprovados para o uso em crianças são a beclometasona, a budesonida, a fluticasona e a ciclesonida. Eles constituem a medicação de escolha para controle da doença em pediatria. A escolha deve levar em conta a gravidade da asma, a medicação já em uso, as propriedades farmacológicas da droga, além dos aspectos econômicos. Os antagonistas de leucotrienos são outra medicação que pode ser considerada. A associação de um antagonista de leucotrieno com um corticoide inalatório para 
tratamento de asma é alternativa preconizada em consensos, especialmente para crianças menores de cinco anos, quando se deve evitar a utilização dos broncodilatadores de ação prolongada (LABAS) (GINA, 2016).

$O$ tratamento tem cinco etapas e cada paciente deve ser situado em uma das etapas, de acordo com o tratamento atual e o seu nível de controle (figura 5). Todas as etapas incluem a promoção da educação e o controle ambiental.

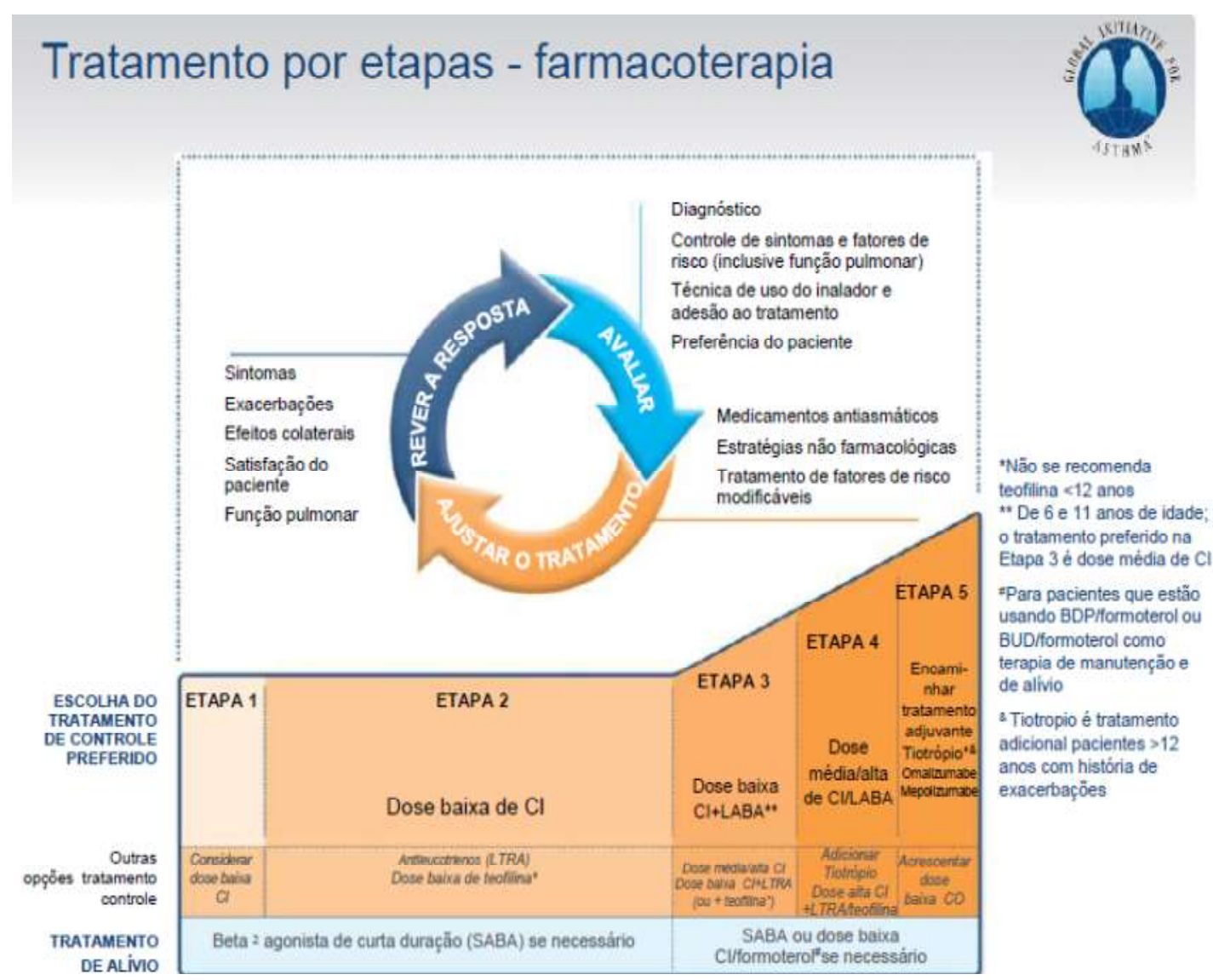

FIGURA 5 - Manejo da asma baseado no nível de controle Fonte: GINA, 2016

O manejo da medicação de controle deve basear-se no diagnóstico, tratamento em curso e presença de sintomas da doença.

O controle da asma promove o controle das limitações atuais e a prevenção dos riscos futuros. Os riscos futuros são avaliados como fatores que podem provocar mudanças irreversíveis na história natural da asma, conforme figura 6. 


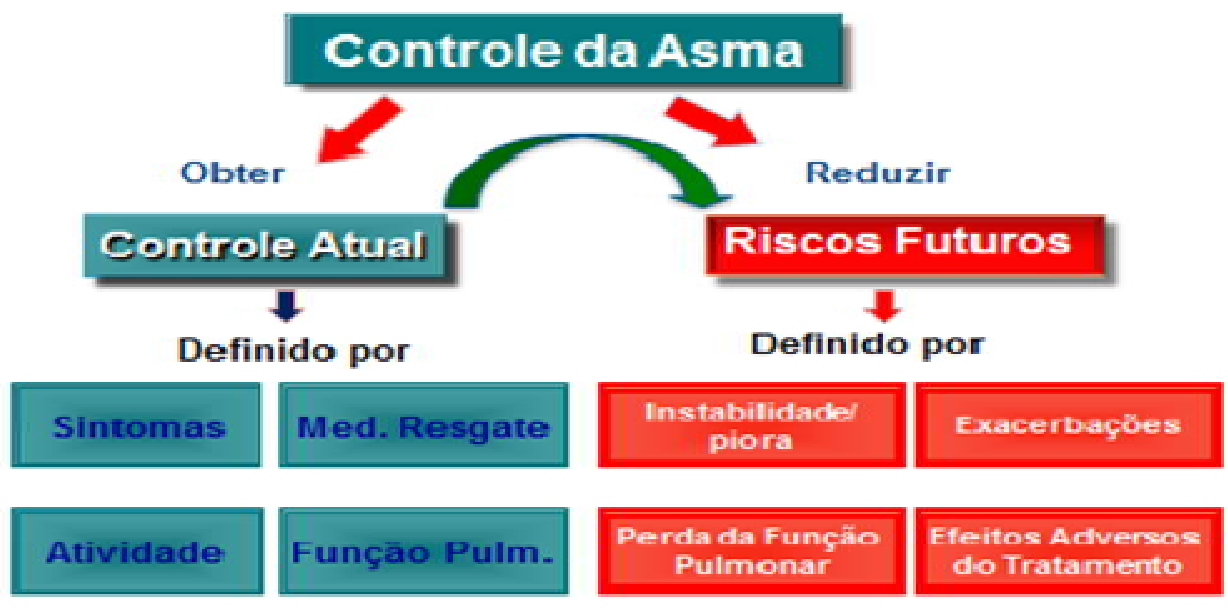

FIGURA 6 - Objetivos do controle da asma Fonte: GINA, 2016

Entretanto, antes disso, deve-se ter em mente que a asma é uma enfermidade de etiopatogenia complexa e influenciada por diversos fatores externos, e a adesão às diversas medidas terapêuticas para asma é difícil, devendo ser reavaliada em todo paciente que não esteja obtendo a resposta esperada ao tratamento (Silva, 2008).

\subsubsection{Tratamento das crises de asma}

As exacerbações representam o desfecho mais importante e temido, por serem o de maior risco para os pacientes, e geram altos custos ao sistema de saúde. São comuns e preveníveis. Estratégias terapêuticas devem prevenir a sua ocorrência (SBPT, 2012).

A história e exame físico, inicialmente, devem ser direcionados, sem perda de tempo. Dados adicionais serão colhidos posteriormente.

O tratamento deve ser baseado nas manifestações clínicas, fundamentado na gravidade da crise, conforme quadro 4 . 
QUADRO 4 - Classificação da intensidade da crise asmática

\begin{tabular}{|c|c|c|c|}
\hline Achado* & Muito grave & Grave & Moderada/leve \\
\hline Gerais & Cianose, sudorese, exaustão & Sem alterações & Sem alterações \\
\hline Estado mental & $\begin{array}{l}\text { Agitação, confusão, } \\
\text { sonolência }\end{array}$ & Normal & Normal \\
\hline Dispneia & Grave & Moderada & Ausente/leve \\
\hline Fala & $\begin{array}{l}\text { Frases curtas } \\
\text { /monossilábicas. Lactente: } \\
\text { maior dificuldade alimentar }\end{array}$ & $\begin{array}{l}\text { Frases incompletas/ } \\
\text { parciais. Lactente: choro } \\
\text { curto, dificuldade alimentar }\end{array}$ & Frases completas \\
\hline Achado* & Muito grave & Grave & Moderada/leve \\
\hline $\begin{array}{l}\text { Musculatura } \\
\text { acessória }\end{array}$ & $\begin{array}{l}\text { Retrações acentuadas ou em } \\
\text { declínio (exaustão) }\end{array}$ & $\begin{array}{l}\text { Retrações subcostais e/ou } \\
\text { Esternocleidomastoides } \\
\text { acentuadas }\end{array}$ & $\begin{array}{l}\text { Retração } \\
\text { intercostal leve ou } \\
\text { ausente }\end{array}$ \\
\hline Sibilos & $\begin{array}{l}\text { Ausentes com MV } \\
\text { localizados ou difusos }\end{array}$ & Localizados ou difusos & $\begin{array}{l}\text { Ausentes com MV } \\
\text { normal/localizados } \\
\text { ou difusos }\end{array}$ \\
\hline $\mathrm{FR}(\mathrm{irm})^{* *}$ & Aumentada & Aumentada & $\begin{array}{l}\text { Normal ou } \\
\text { aumentada }\end{array}$ \\
\hline $\mathrm{FC}(\mathrm{bpm})$ & $>140$ ou bradicardia & $>110$ & $\leq 110$ \\
\hline $\begin{array}{l}\text { PFE (\% } \\
\text { melhor ou } \\
\text { previsto) }\end{array}$ & $<30 \%$ & $30-50 \%$ & $>50 \%$ \\
\hline $\begin{array}{l}\mathrm{SaO}_{2}(\mathrm{ar} \\
\text { ambiente) }\end{array}$ & $<90 \%$ & $91-95 \%$ & $>95 \%$ \\
\hline $\begin{array}{l}\mathrm{PaO}_{2} \text { (ar } \\
\text { ambiente) }\end{array}$ & $<60 \mathrm{mmHg}$ & Ao redor de $60 \mathrm{mmHg}$ & Normal \\
\hline $\begin{array}{l}\mathrm{PaCO}_{2}(\mathrm{ar} \\
\text { ambiente) }\end{array}$ & $>45 \mathrm{mmHg}$ & $<40 \mathrm{mmHg}$ & $<40 \mathrm{mmHg}$ \\
\hline
\end{tabular}

${ }^{*}$ A presença de vários parâmetros, mas não necessariamente todos, indica a classificação geral da crise. ** FR em crianças normais: < 2 meses, < 60/min; 2-11 meses, < 50/min; 1-5 anos, < 40/min; 6-8 anos, <30 /min; > 8 anos $=$ adulto.

MV: murmúrio vesicular; FR: frequência respiratória; FC: frequência cardíaca; PFE: pico de fluxo expiratório; SaO2: saturação de oxigênio no sangue arterial; $\mathrm{PaO}_{2}$ : pressão parcial de oxigênio no sangue arterial; $\mathrm{PaCO}_{2}$ : pressão parcial de gás carbônico no sangue arterial

Fonte: SBPT, 2012

Doses repetidas de beta-2 agonistas por via inalatória a cada 10 a 30 minutos na primeira hora constituem a medida inicial de tratamento. $\mathrm{Na}$ crise grave, a utilização de brometo de ipratrópio em doses repetidas, administrado com beta-2 agonistas de curta duração por nebulização ou por aerossol dosimetrado é recomendada. Beta-2 agonista de curta duração administrado por via intravenosa é alternativa farmacológica e deve ser utilizado quando se pretende evitar a evolução para insuficiência respiratória e a necessidade de suporte ventilatório, especialmente em pacientes pediátricos, portadores de quadros graves (Browne; Lam, 2002). Nas crises moderadas e graves, o oxigênio 
precisa ser utilizado. A administração pode ser feita por cânula nasal a 2 litros por minuto, máscara facial (simples ou Venturi), campânula ou tenda (GINA, 2016).

Em crianças, a meta é manter a saturação de oxigênio no sangue arterial maior ou igual a 95\% Corticosteroides reduzem a inflamação, aceleram a recuperação e diminuem o risco de crise. Os pacientes atendidos na emergência devem receber corticosteroides sistêmicos precocemente, já na primeira hora de atendimento. Os usos de corticosteroide por via oral ou endovenosa têm efeito equivalente (GINA, 2016).

O quadro 5 estabelece resumidamente as etapas de tramento da crise asmática, conforme protocolo médico do Programa Respirar (Minas Gerais, 2015).

QUADRO 5 - Etapas de tratamento da crise asmática

\begin{tabular}{|c|c|c|}
\hline Primeira fase: 60 a 90 minutos & Segunda fase: $4-6$ horas & $\underline{\text { Fase Hospitalar }}$ \\
\hline $\begin{array}{l}\text { *Salbutamol inalado }-100 \mathrm{mcg} / j a t o \\
4-10 \text { jatos para }>5 \text { anos e } 2-6 \text { jatos } \\
\text { para < } 5 \text { anos (aerossol c/ } \\
\text { espaçador) } \\
\text { fenoterol nebulizado: } \\
\text { 1gt para } 1,5-2 \mathrm{~kg} \\
\text { Intervalo das doses: } 20 / 20 \text { min } \\
\text { No de doses: até } 3 \\
\text { *Corticoide VO / EV (crises } \\
\text { moderadas e graves) ou se o } \\
\text { paciente é corticodependente } \\
\text { *Brometo de Ipratrópio se resposta } \\
\text { pobre ao broncodilatador e } \\
\text { corticoide e crise grave } \\
\text { *Decisão: alta (após } 60 \text { minutos se } \\
\text { estável) / manter PA / internação } \\
\text { Se alta: aumentar Cl por } 2-4 \\
\text { semanas, reforçar adesão e } \\
\text { cuidados, controle ambulatorial em } \\
2-7 \text { dias }\end{array}$ & $\begin{array}{l}\text { "Salbutamol: } 4-10 \text { jatos } \\
\text { para > } 5 \text { anos e 2-6 jatos } \\
\text { para < } 5 \text { anos (aerossol } \\
\text { c/ espaçador } \\
\quad \text { ou } \\
\text { fenoterol nebulizado: } \\
\text { 1gt para 1,5-2 kg } \\
\text { Intervalo: cada 1-2h ou 3- } \\
\text { 4h } \\
\text { *Brometo de Ipratrópio se } \\
\text { resposta pobre ao } \\
\text { broncodilatador e } \\
\text { corticoide } \\
\text { * Decisão: alta / } \\
\text { internação em enfermaria } \\
\text { / internação em UTI }\end{array}$ & $\begin{array}{l}\text { - Salbutamol ou fenoterol } \\
\text { inalatório + Brometo de } \\
\text { Ipratrópio S/N } \\
\text { - Corticoide VO / E.V. } \\
\text { - } \mathrm{O}_{2} \mathrm{~S} / \mathrm{N} \\
\mathrm{UTI} \\
\text { - Salbutamol E.V. } \\
\text { - Metilprednisolona E.V. } \\
\text { - Sulfato de magnésio } \\
\text { - } \mathrm{O}_{2} \mathrm{~S} / \mathrm{N} T E T+V M\end{array}$ \\
\hline
\end{tabular}

${ }^{*} \mathrm{O}_{2}$ para $\mathrm{SatO}_{2}<$ ou igual $94 \%$

${ }^{*} \mathrm{~A}$ avaliação da resposta terapêutica deve ser realizada em 30-60min. Após o tratamento inicial, com reclassificação da gravidade do paciente.

*Pacientes pediátricos, sem resposta ao tratamento usual, considerar o uso de nebulização contínua (salbutamol 0,3-0,5mg/kh/h - diluir em SF0,9\% e acoplar a sistema de bomba de infusão, taxa 12-14ml/h; melhor tolerado em $>4$ anos)

Fonte: Minas Gerais, 2015 
Exames complementares geralmente não são indicados nas crises de asma leves e moderadas. O quadro 6 relaciona as principais indicações.

QUADRO 6 - Indicações de exames complementares na crise asmática

\begin{tabular}{|l|l|}
\hline Gasometria & $\begin{array}{l}\text { Sinais } / \text { sintomas de quadro grave, PFE < } 30 \% \text { após tratamento } \\
\text { ou } \mathrm{SaO}_{2}<93 \%\end{array}$ \\
\hline Radiografia de tórax & $\begin{array}{l}\text { Exacerbação grave ou suspeita de comorbidade, complicações } \\
\text { tais como Pneumonia, ICC e Pneumotórax }\end{array}$ \\
\hline Hemograma & $\begin{array}{l}\text { Suspeita de infecção. Neutrófilos aumentam quatro horas após } \\
\text { o uso de corticosteroides sistêmicos }\end{array}$ \\
\hline Eletrólitos & $\begin{array}{l}\text { Coexistência com doenças cardiovasculares, uso de diuréticos } \\
\text { ou altas doses de beta-2 agonistas, especialmente se } \\
\text { associados a xantinas e corticosteroides }\end{array}$ \\
\hline
\end{tabular}

Fonte: SBPT, 2012

\subsubsection{Abordagem das comorbidades}

Situações especiais no manejo da asma incluem o tratamento das comorbidades muitas vezes presentes.

A via aérea é considerada uma única via do nariz aos brônquios (GINA, 2016). A rinite deve ser sempre investigada e avaliada tanto na admissão como durante o seguimento e suspensão da cortocoterapia inalatória, sendo o principal fator de risco para o desenvolvimento da asma. Em algumas situações, a manutenção do tratamento da rinite alérgica pode prevenir novas exacerbações. O tratamento simultâneo da asma e rinite alérgica, quando presente, deve incluir a técnica de inalação nasal do corticosteroide em maiores de cinco anos, em espaçador com máscara inalado por trinta segundos pelo nariz, com a boca fechada; nos menores, o tratamento tópico da rinite alérgica deve ser considerado (Alvim et al., 2009).

Outras comorbidades frequentemente presentes são: rinossinusites, refluxo gastroesofagiano, obesidade, conjuntivite alérgica, entre outras.

\subsubsection{Educação ambiental}

Enfoque especial deve ser dado à tentativa de reduzir os reservatórios de ácaros. É necessário que o ambiente seja arejado. Baratas devem ser eliminadas. Usar capas impermeáveis em colchões e travesseiros. Fumaça deve ser evitada. Atenção especial com o tabagismo domiciliar. O cuidado não deve limitar-se ao domicílio, mas também deve ser implementado em outros locais 
mais frequentados pelo paciente, como casa de avós, escola. Atividades físicas prazerosas devem ser estimuladas, pois melhoram a capacidade física, a postura e a autoestima. Não há evidência de superioridade da natação (SBPT, 2012).

\subsubsection{Parceria médico, paciente e familiares}

A educação associada ao tratamento farmacológico é parte integral do cuidado ao asmático em qualquer idade (Fontes, 2013). É importante que o paciente (quando aplicado) e familiares sejam capazes de reconhecer e evitar os fatores desencadeantes, reconhecer os sinais e sintomas de pré-crise e crise e ter um plano de tratamento escrito e individualizado para seu próprio manejo. Os medicamentos em uso devem ser bem conhecidos (controladores e de alívio). $\mathrm{O}$ controle da doença deve ser monitorado. A técnica inalatória deve ser orientada e reavaliada em toda consulta. A adesão deve ser rigorosamente avaliada e estimulada (Minas Gerais, 2015).

\subsection{Programas de controle da asma}

Não há cura definitiva para a asma, mas é possível aliviar os sintomas e permitir que as pessoas tenham uma vida absolutamente normal (Cerci Neto, 2007). Neste contexto destaca-se a importância dos programas de controle da asma, e ilustramos a divulgação com a figura 7 .

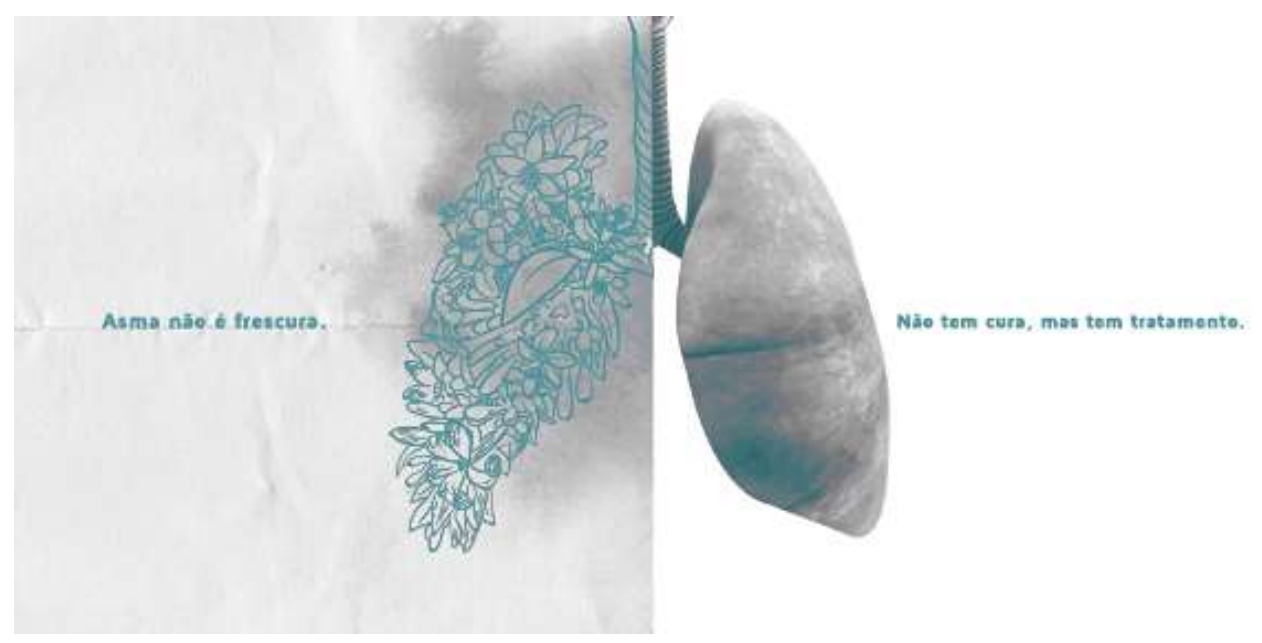

FIGURA 7 - Slogan da asma

Fonte: GINA, 2016 


\subsubsection{Programas de controle da asma no mundo}

Em 1989, o programa Iniciativa Global para a Asma (GINA) foi iniciado em um esforço para aumentar a conscientização entre a saúde pública e funcionários do governo, profissionais de saúde e do público em geral, chamando atenção para o aumento da asma. GINA recomenda um programa de gestão baseado na melhor evidência científica disponível para fornecer cuidados médicos eficazes para asma adaptados aos sistemas locais de saúde e recursos (Masoli et al., 2004).

O GINA estabeleceu um resumo que justifica sua atividade, conforme descrito por Masoli et al. (2004):

- A asma é uma das doenças crônicas mais comuns no mundo. Estima-se que cerca de 300 milhões de pessoas no mundo atualmente têm asma. Estimativas consideravelmente maiores podem ser obtidas com critérios menos conservadores para o diagnóstico de asma clínica.

- Os padrões internacionais de prevalência de asma não são explicados pelo conhecimento atual da causa da asma. A investigação sobre a causa da asma e a eficácia das estratégias de intervenção primária e secundária representam áreas prioritárias fundamentais no campo da investigação da asma.

- A asma tornou-se mais comum em crianças e adultos em todo o mundo nas últimas décadas. O aumento da prevalência de asma tem sido associado a um aumento na sensibilização atópica e é paralelo por aumentos semelhantes em outras doenças alérgicas, como eczema e rinite.

- A taxa de asma aumenta à medida que as comunidades adotam estilos de vida ocidentais e se tornam urbanizadas. Com o aumento projetado da proporção da população mundial que é urbana de 45\% para 59\% em 2025, é provável que haja um aumento acentuado no número de asmáticos em todo o mundo ao longo das próximas duas décadas. Estima-se que pode haver mais 100 milhões de pessoas com asma até 2025.

- Em muitas áreas do mundo as pessoas com asma não têm acesso a medicamentos básicos de asma ou cuidados médicos. Aumentar a riqueza econômica e melhorar a distribuição dos recursos entre e dentro dos 
países representam prioridades importantes para permitir melhores cuidados de saúde.

- O número de anos de vida ajustados por incapacidade (DALYs) perdidos devido à asma em todo o mundo foi estimado em cerca de 15 milhões por ano. Em todo o mundo, a asma responde por cerca de $1 \%$ de todos os DALYs perdidos, o que reflete a elevada prevalência e gravidade da asma. O número de DALYs perdidos devido à asma é semelhante ao da diabetes, cirrose do fígado ou esquizofrenia.

- O fardo da asma em muitos países é de magnitude suficiente para justificar seu reconhecimento como uma desordem prioritária nas estratégias governamentais de saúde. Devem ser fornecidos recursos específicos para melhorar o atendimento de grupos desfavorecidos com alta morbidade, incluindo certos grupos raciais e aqueles com pouca instrução, que vivem em grandes cidades ou são pobres. Os recursos também precisam ser fornecidos para tratar fatores evitáveis, como a poluição do ar, que desencadeiam exacerbações da asma.

- Estima-se que a asma representa cerca de uma em cada 250 mortes em todo o mundo. Muitas das mortes são evitáveis, sendo devido a cuidados médicos subótimos a longo prazo e atraso na obtenção de ajuda durante o ataque final.

- O custo econômico da asma é considerável, tanto em termos de custos médicos diretos (como internações hospitalares e custo de produtos farmacêuticos) como de custos médicos indiretos (como perda de tempo de trabalho e morte prematura).

- Até que haja uma maior compreensão dos fatores que causam asma e novas medidas de saúde pública e farmacológicas estejam disponíveis para reduzir sua prevalência, a prioridade é garantir que abordagens de gestão de custo-eficácia, que têm sido comprovadas para reduzir a morbidade e mortalidade, estejam disponíveis para o maior número possível de pessoas com a doença em todo o mundo.

O GINA é atualizado a partir da análise de pesquisas publicadas relativas ao manejo e prevenção da asma e da avaliação do impacto que estas teriam sobre suas diretrizes (GINA, 2016). 
Trabalhando em colaboração contínua com líderes em atendimento de asma de muitos países, GINA patrocina o Dia Mundial da Asma (primeira terçafeira em maio), que tem sido extremamente bem-sucedido. Um grande número de pessoas se comprometeu a conscientizar os profissionais de saúde locais sobre o ônus da asma e a implementar programas de assistência eficazes (Masoli et al., 2004)

Apesar dos esforços de divulgação e de pesquisas internacionais, há evidências claras de que o controle da asma está abaixo do ideal em muitos países, mesmo com a disponibilidade de terapias muito eficazes. Como o relatório GINA pretende melhorar o atendimento de asmáticos, esforços devem ser feitos para estimular os responsáveis pelos cuidados de saúde a garantirem ao paciente o acesso ao medicamento e desenvolverem programas adaptados para o manejo e controle da asma, que prevejam ferramentas adequadas para medir o sucesso destes (GINA, 2016).

Em muitos países observaram-se, nas últimas décadas, esforços para desenvolver programas de manejo e controle da asma. No entanto, há limitações para a sua aplicação na atenção primária à saúde, o que requer um grande esforço para adaptar as diretrizes baseadas em evidências à realidade da clínica médica. Alguns trabalhos descrevem sumariamente a implantação de programas de manejo e controle da asma, conforme o preconizado pelo GINA, e afirmam essa dificuldade (Guarnaccia et al., 2007; Bhulani et al., 2011; Boulet et al., 2012).

Considerando alguns exemplos de programas de manejo e controle da asma no mundo, pode-se citar o programa instalado no Vietnã. Segundo Nguyen (2011), as diretrizes do GINA foram recentemente adotadas como principal fonte de referência para as diretrizes nacionais do país, já que a doença ocorre em cerca de $5 \%$ da população.

Sepúlveda (2011) fez um pequeno relato sobre os desafios enfrentados pelo governo do Chile ao implantar um programa de controle de asma denominado Programa para o Manejo das Doenças Crônicas em Adultos (ACRD), que inclui diretrizes clínicas baseadas em evidências e em consensos internacionais.

Castillo e Garay (2011) relataram o impacto do programa de controle de asma em El Salvador, adotado pelo Programa Nacional de Tuberculose e 
doenças pulmonares em 2005 e chamado de estratégia PAL (Abordagem Prática para Doenças Pulmonares), que se fundamenta no que foi preconizado pelas diretrizes do GINA.

O programa de manejo e controle da asma na Finlândia foi implantado em 1994 e norteou-se por vários objetivos, entre eles a redução do número de internações em $50 \%$ e a redução dos custos anuais/pacientes em $50 \%$. As diretrizes para o manejo baseado em evidências são disponibilizadas para os profissionais de saúde via internet desde 2000, além dos planos de ação e os protocolos (Haahtela; Pietinalho, 2011).

Aït-Khaled et al. (2007) descreveram o impacto e os desafios de um Programa de Controle da Asma no Sudão. Relatam que o Sudão, que não havia implantado as diretrizes para o manejo de asma em 2002, passou a utilizar as recomendações da La Unión, como base para um primeiro documento intitulado "Orientações para o Tratamento da Asma no Sudão", que tornava obrigatório o uso de apenas medicamentos considerados essenciais, diante da escassez de recursos do país.

Bhulani et al. (2011) estudaram a avaliação do manejo da asma por clínicos gerais, considerando o protocolo do GINA, em Karchi, Paquistão. Nesse estudo observa-se a existência de um programa de manejo e controle da asma na área em questão, que segue as diretrizes do GINA. No entanto, resultados preocupantes são apontados nesse trabalho, tais como: $28,6 \%$ dos clínicos gerais tinham conhecimento dos conceitos fundamentais da asma, enquanto apenas $10,4 \%$ tinham prática adequada seu manejo; cerca de $78 \%$ deles tinham conhecimento inadequado da patologia e $90 \%$ tinham conhecimento inadequado de medicamentos a serem utilizados; as práticas relativas ao diagnóstico da asma foram boas $(99,0 \%)$, no entanto, práticas relativas em exacerbações agudas $(85,9 \%)$ foram classificadas como inadequadas. Concluem que a maioria dos clínicos gerais entrevistados tinha pouco conhecimento e prática no controle e tratamento da asma e recomendam o desenvolvimento de um programa para melhorar essa realidade.

Outro exemplo de estratégia para o controle da asma foi descrito por Guarnaccia et al. (2007). Os autores elaboraram e implantaram um protocolo para o diagnóstico e para a terapêutica da asma baseado nas diretrizes do GINA, com 
a contribuição de 19 especialistas na Itália. Esse protocolo foi utilizado em 60 dos 113 centros de atenção primária em saúde na região de Brescia. Concluíram que visitas regulares ao especialista, website e um plano de manejo impresso e distribuído a todos os envolvidos levam à melhora clínica, assim como diminuem os custos e aumentam a eficiência no uso de medicamentos para a asma.

Ställberg et al. (2009) relatam que na Suécia existe um programa de controle de asma baseado nas diretrizes do GINA e que é estruturado em centros de atenção primária, mas os níveis de asma sem controle permanecem altos.

Programa Nacional de Controle da Asma foi criado em Portugal, coerente com a preocupação mundial relativa ao controle da doença, impulsionado, sobretudo, pelo movimento que levou à elaboração e implantação de diretrizes internacionais como o GINA e justificado pela alta taxa de prevalência de asma no país e pelos custos diretos e indiretos dessa patologia (Portugal, 2008).

\subsubsection{Programas no Brasil}

A asma ainda é um reconhecido problema de saúde pública, mesmo com a implantação de programas para o seu controle que visam a melhoria na qualidade da assistência e a redução da mortalidade (Fontes et al., 2013).

Programas de asma têm sido implantados em muitos países como estratégia importante para o controle da doença, por meio da realização do diagnóstico e tratamento precoces, com fornecimento de medicações, plano de tratamento nas exacerbações, redução da exposição a fatores desencadeantes e reabilitação. Essa estratégia tem como resultado um impacto positivo para a sociedade e serviços de saúde, por permitir melhor organização na assistência para os portadores de asma, os quais requerem tratamento diferente do habitual, por envolver medicações inalatórias (SBPT, 2012).

Há muitos anos, as associações médicas envolvidas com essa doença, tais como a Sociedade Brasileira de Pneumologia e Tisiologia (SBPT), a Sociedade Brasileira de Pediatria (SBP), a Associação Brasileira de Alergia e Imunologia (ASBAI), a Sociedade Brasileira de Medicina de Família e Comunidade (SBMFC) e a Associação Brasileira de Asmáticos (ABRA), lutam pela criação e implantação, em nosso país, de um Plano Nacional de Asma. O envolvimento e comprometimento efetivo do Ministério da Saúde com essas 
associações, por meio do Departamento de Atenção Básica, do Departamento de Assistência Farmacêutica e do Conselho Nacional de Secretários Municipais de Saúde, vêm transformando esse sonho em realidade (Cerci Neto, 2007), reconhecendo a importância da criação de Programas de Asma no Brasil.

O Ministério da Saúde, em junho de 1999, reconheceu a gravidade da doença e propôs a disponibilização de recursos e a criação de um Programa Nacional de Controle da Asma (PNCA), incentivado em 2001, no $3^{\circ}$ Congresso Brasileiro de Asma, realizado em Salvador, quando foi lançada a Carta de Salvador, como manifestação da necessidade de implantação imediata do Programa Nacional de Controle da Asma (PNCA) (Cerci Neto, 2007).

Cada vez mais, considera-se de fundamental importância para a assistência médica a uniformização de condutas. A organização assistencial aos pacientes do Sistema Único de Saúde (SUS) limita-se, na maioria das vezes, ao tratamento das crises, com assistência pontual e fragmentada, gerando riscos de vida aos portadores da doença e realização de exames desnecessários ou que poderiam ser evitados com o acompanhamento adequado e controle da doença (Cerci Neto, 2007).

Foram criados, então, alguns programas de controle e atenção à asma que geraram experiências acumuladas de tratamento multiprofissional, controle da doença, redução da morbidade e da procura pelos serviços de urgência.

Belo Horizonte foi a primeira cidade a implantar um programa de asma em larga escala no Brasil. Em 1994, foi criado o ambulatório-piloto Campos Sales, no Distrito Sanitário Oeste, onde foi conduzido estudo demonstrando que $89,9 \%$ dos pacientes com asma frequentavam os serviços de urgência regularmente e que $64 \%$ deles já haviam sido internados. Esses dados subsidiaram a reorganização da assistência pública aos pacientes asmáticos, o programa "Criança que Chia", fruto da parceria entre a Secretaria Municipal de Saúde e Assistência (SMSA) e a Faculdade de Medicina da Universidade Federal de Minas Gerais (UFMG), permitindo que a atenção primária passasse a ocupar o papel de referência no tratamento. O programa uniformizou condutas, promoveu a educação em saúde aos pacientes, capacitou as equipes para o atendimento e disponibilizou os insumos necessários. A partir de então, observou-se um salto na 
qualidade da assistência. A experiência de Belo Horizonte serviu de modelo para várias cidades do estado e do país (Fontes et al., 2013).

Lasmar et al. (2009), quando analisaram o impacto do programa "Criança que Chia", planejado segundo as orientações do guia para manejo e controle da asma proposto pelo GINA, concluíram que o programa foi capaz de reduzir, de maneira significativa, o número de internações e de atendimento de urgência, no período de 2000 a 2007, além de melhorar a qualidade de vida dos pacientes. Afirmaram também que o programa pode ser implantado em qualquer país de renda média e que a equipe multidisciplinar terá como desafio aperfeiçoar o controle da asma e aumentar a adesão ao tratamento.

Outros programas para controle da asma foram criados no país a partir de 1996, como aqueles implantados no Nordeste do Brasil, entre eles o "Programa de Atenção Integral à Saúde da Criança Asmática em Fortaleza", Ceará, cujos objetivos eram reduzir a morbidade, melhorar o controle da doença, reduzir a necessidade de consultas de urgência e emergência e reduzir o número de hospitalizações por asma, diminuindo assim os custos da doença. Criou-se também o "Programa de Assistência ao Paciente Asmático de São Luís", Maranhão (Cerci Neto, 2007; Cerci Neto; Ferreira; Bueno, 2008).

No ano de 1998, foi instituída pelo governo brasileiro a Política Nacional de Medicamentos, pela Portaria $n^{\circ} 3.916 / G M / M S$, como parte das ações de descentralização em saúde no país, o que facilitou as modificações nas medicações para controle da asma e impactou os programas de controle da doença (Cerci Neto, 2007).

O histórico foi relatado por Kashiwabara (2016), segundo Cerci Neto (2007), que descreveu que em 1999 foi implantado o programa de controle da asma do Distrito Federal, denominado "Programa de Atendimento ao Paciente Asmático do Distrito Federal". Em 2000, lançou-se no Paraná o programa "Crescendo com Saúde: Infecções e Alergias Respiratórias na Infância", e em 2001, Porto Alegre lançou o programa de manejo de asma denominado "De Volta para Casa e Asma". Em 2002, além da implantação do "Programa de Manejo de Asma em Londrina", houve a assinatura da Portaria $\mathrm{n}^{\circ} 1.318 / \mathrm{GM}$, que foi atualizada pela Portaria $n^{\circ}$ 921/SAS/MS, de novembro de 2002, que determinava que a Secretaria de Atenção à Saúde adotasse as providências para elaboração 
de diretrizes terapêuticas e protocolos clínicos para o manejo da asma grave, disponibilizando inclusive medicamentos em caráter excepcional apenas aos portadores de asma grave. A partir de 2003, houve grande envolvimento do governo federal no desenvolvimento de ações como o financiamento de medicamentos para a asma grave, e veio garantir a aquisição de medicamentos para asma leve e moderada, o que colocou os programas de asma no centro das políticas públicas. Em 2003, ocorreu também a implantação do Plano Municipal da Asma, que foi anteriormente denominado "Catavento Programa de Controle da Asma em Goiânia", numa parceria entre a Faculdade de Medicina da Universidade Federal de Goiás e a Secretaria Municipal de Saúde de Goiás. Naquele ano surgiu também o "Plano de Controle da Asma" da cidade de Niterói, Rio de Janeiro, que contava com dois níveis de atenção, o básico e o de referência. A atenção básica no programa era conduzida pelas unidades básicas de saúde, programas de saúde da família e policlínicas comunitárias, enquanto no que diz respeito a referência, os pacientes seriam encaminhados pelo nível básico para os sistemas de referência (Cerci; Ferreira; Bueno, 2008). O ano de 2004 foi marcado por vários fatos, como a publicação intitulada "Linhas de Conduta em Atenção Básica - Asma e Rinite", que teve como objetivo a correção das abordagens que eram anteriormente restritas ao tratamento sintomático das exacerbações da doença. Além disso, ampliou-se o "Programa de Controle de Asma de Londrina" para as 52 US do município e implantou-se o Programa Pro-Ar de Feira de Santana, Bahia, com o apoio do "Programa Pro-Ar" de Salvador, Bahia. Também em 2004, foi elaborado o "Plano de Atenção ao Paciente com Asma e Rinite no Município do Rio de Janeiro", que tinha como objetivo geral reduzir a morbidade e mortalidade por asma no município e os principais objetivos incluíam capacitar profissionais da rede de atendimento, promover educação permanente para os profissionais, aperfeiçoar o sistema de informação e aumentar a cobertura do acompanhamento de asmáticos, por meio de implantação de novos polos de asma. Em 2005 foi implantado o Centro de Referência em Asma para adolescentes e adultos no município de Vitória, contando com uma equipe multidisciplinar, com o "Programa de Controle de Rinite e Asma da Santa Casa de Misericórdia de Vitória", Espírito Santo, desenvolvido em parceria com a prefeitura municipal 
Em 2009 é criada a Portaria $n^{0}$ 2.981, que aprova o componente especializado da assistência farmacêutica, bem como a Portaria $n^{\circ} 4.217$, em 2010, na qual são aprovadas as normas de financiamento e execução do Componente Básico da Assistência Farmacêutica, incluindo medicamentos de referência nacional e destinando-os aos programas de asma e rinite (Cerci Neto, 2007).

Em 2012 foram publicadas no Brasil as "Diretrizes da Sociedade Brasileira de Pneumologia e Tisiologia para o Manejo da Asma", descrevendo os cuidados para o manejo da asma. Foi também lançado o programa "Brasil Carinhoso", que inclui ações voltadas para o combate da pobreza infantil e prevê a distribuição gratuita de três medicamentos para o tratamento da asma (brometo de ipratrópio, beclometasona e salbutamol) por meio do programa "Saúde Não Tem Preço" (Amaral; Palma; Leite, 2012).

Finalmente, Cerci, Ferreira e Bueno (2008) concluíram que, apesar das limitações do estudo, já existe no Brasil experiência, bem como profissionais em número suficiente, com importante acúmulo de informações, que muito contribuiriam para criar um programa nacional de capacitação profissional em asma e também para estimular a possível criação de novas estratégias em saúde pública.

A figura 8 mostra alguns dos programas de controle da asma existentes no Brasil.

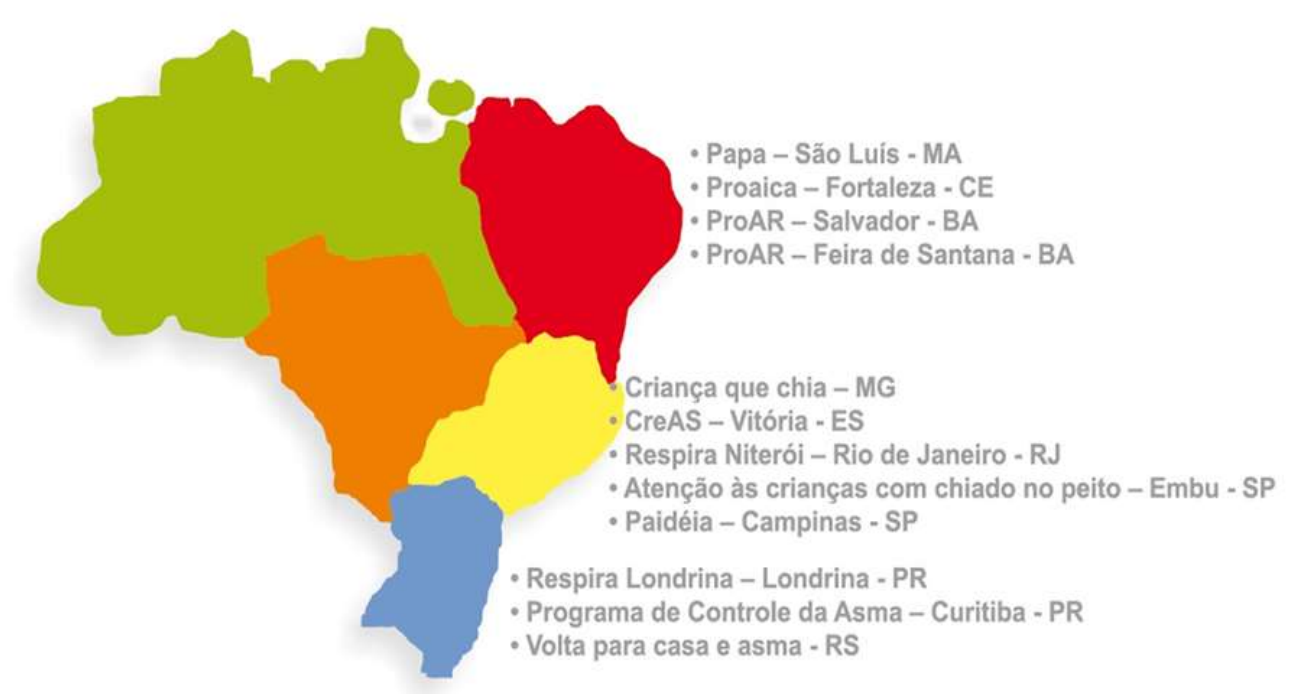

FIGURA 8 - Programas de Asma no Brasil

Fonte: Cerci Neto, 2007 


\subsubsection{Programa de Asma de Ipatinga - Programa Respirar}

A Região Metropolitana do Vale do Aço (RMVA) é um dos maiores polos industriais de Minas Gerais, onde estão localizadas duas indústrias siderúrgicas (Usiminas e Aperam) e uma indústria de extração de celulose (Cenibra), além de diversas micro e pequenas empresas. Os municípios de Coronel Fabriciano e Ipatinga, juntamente com Timóteo e Santana do Paraíso, constituem a RMVA. Trata-se de uma aglomeração urbana com aproximadamente 470.000 habitantes. Somadas as populações dos outros 11 municípios que formam o colar metropolitano, a região atinge mais de $600 \mathrm{mil}$ habitantes, conforme dados do IBGE (2010). A figura 9 ilustra a região.

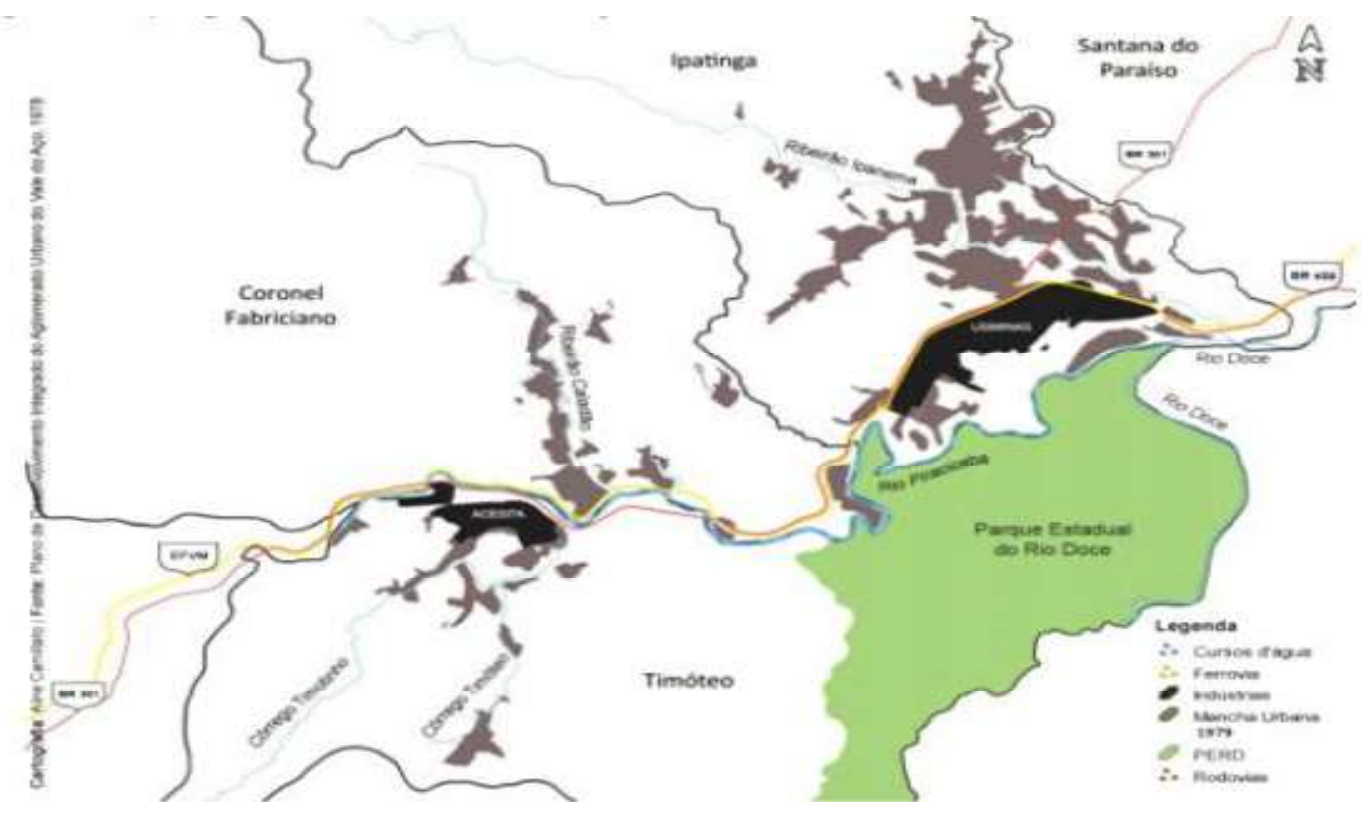

FIGURA 9 - Mapa aglomerado urbano do Vale do Aço (AUVA)

Fonte: Eixo de Ordenamento Territorial extraído do Plano Diretor de Desenvolvimento Integrado - Região Metropolitana do Vale do Aço, 2014

Ipatinga é uma cidade localizada no leste de Minas Gerais, com cerca de 260.000 habitantes, segundo dados do IBGE (2010), com área da unidade territorial de 164,884 km². Seu histórico relata em 12/12/1953 a criação do distrito de Ipatinga, pertencendo ao Município de Coronel Fabriciano, através da Lei Estadual 1.039; em 26/10/1962 a inauguração da Usina Intendente Câmara (Usiminas); em 30/12/1962 a Assembléia Legislativa de MG aprovou em redação final o projeto de revisão administrativa, que criou 237 novos municípios. Entre 
eles estava Ipatinga, e a emancipação político-administrativa se deu em 29/04/1964 (Prefeitura Municipal de Ipatinga, 2016). Considerando o Índice de Desenvolvimento Humano (IDH), que utiliza certos critérios para essa avaliação como renda, longevidade e educação, em Ipatinga é de 0,771 , classificando-se como cidade de médio desenvolvimento.

Ipatinga é hoje o município industrial mais próspero do leste do estado de Minas Gerais. A economia baseia-se principalmente na siderurgia, representada pela empresa Usiminas - Usina Intendente Câmara, que se instalou na região em meados dos anos 50 , no século XX. Logo após, iniciou-se o zoneamento urbano da cidade em bairros de acordo com a hierarquia da empresa. Este município, atualmente, passa por um processo de diversificação econômica, com a implantação de um distrito industrial que vem estimulando o empreendedorismo e a abertura de novas e diferentes plantas industriais (Araújo, 2011). A figura 10 ilustra a localização de Ipatinga.
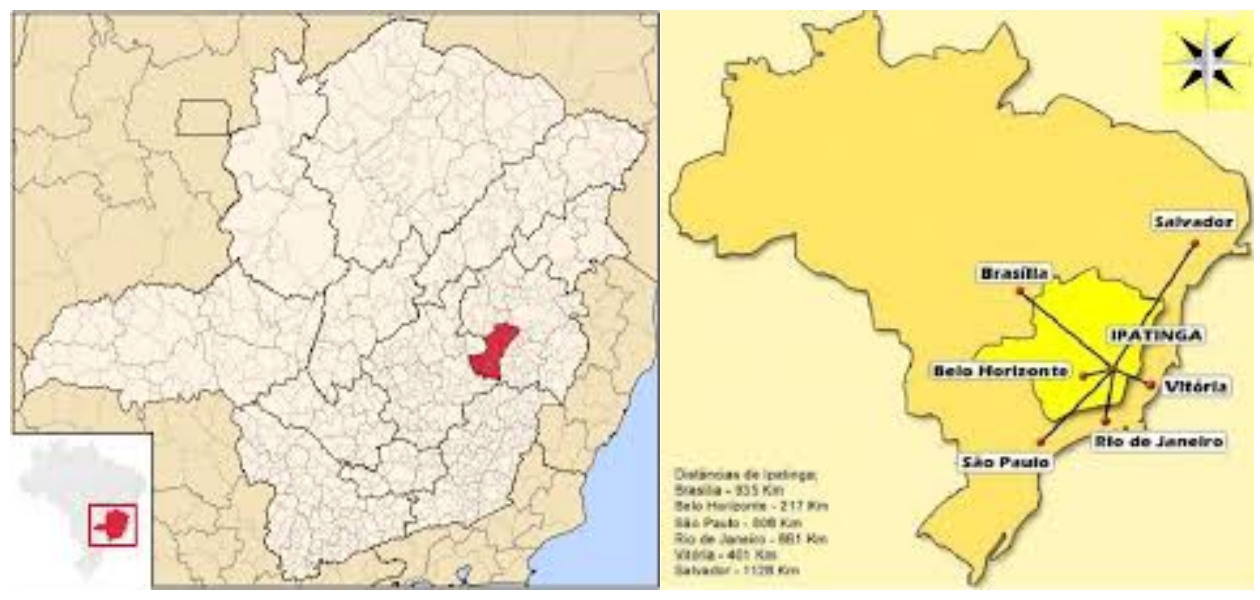

FIGURA 10 - Localização de Ipatinga

Fonte: Prefeitura Municipal de Ipatinga, CENFOP, 2017

As principais fontes de poluição atmosférica na RMVA são siderurgia, indústrias de transformação, queimadas e tráfego de veículos, o que torna importante a quantificação de elementos químicos que se aglomeram no material particulado. A provável concentração elevada de material particulado no ar da RMVA pode levar a problemas respirátorios na população. Desta forma, o número de internações por doenças respiratórias nos hospitais da região pode estar relacionado à quantidade de material particulado oriundo de atividades dentro da região (Araújo, 2011). 
Fator relevante relaciona-se à questão da poluição atmosférica presente devido à presença de indústrias, principalmente a siderúrgica, e ao grande tráfego de veículos. Esta poluição se faz sentir em Ipatinga, sede da indústria siderúrgica (Araújo, 2011).

A saúde pública do município conta com 20 unidades de saúde, todas com programas de saúde da família, além de uma UPA (Unidade de Pronto Atendimento), uma policlínica com atendimento secundário e um Hospital municipal. As crianças que necessitam internação são atendidas no hospital Márcio Cunha, entidade filantrópica com $74 \%$ de atendimentos dedicados ao SUS.

Em Ipatinga foi criado, pela Secretaria Municipal de Saúde, em 2003, o Programa Respirar, como forma de identificar e tratar, de forma diferenciada, os pacientes portadores de asma não controlada (classificados anteriormente como persistentes). O projeto se justificou pela grande prevalência da doença, especialmente considerando ser a cidade um polo siderúrgico e pelo grande impacto social e econômico da asma em termos mundiais, a despeito dos avanços do conhecimento da patogênese e terapêutica (Minas Gerais, 2007).

Segundo dados do DATASUS, a taxa de asmáticos em maiores de 13 anos na cidade de Ipatinga, em 2004 , foi estimada em cerca de $25 \%$. A presença da asma como um fator determinante para a elevação da taxa de morbidade originou uma preocupação para a necessidade de implantação de um programa de controle e profilaxia da patologia, que pretende reduzir as taxas desta enfermidade, proporcionando a redução de gastos com a assistência e medicamentos e melhorando a qualidade de vida individual e familiar dos pacientes, com redução das sequelas físicas e emocionais (Minas Gerais, 2007).

Em 2005, as doenças do aparelho respiratório foram responsáveis pela hospitalização de 681 pacientes, colocando a asma como a segunda patologia mais prevalente no município. Além disso, com 102 pacientes internados naquele ano, a doença passa a ser responsável por $15 \%$ do total das internações segundo Kashiwabara, 2016.

Os estudos de prevalência da asma em Ipatinga, no período de 2000 a 2012, obtiveram resultados preocupantes quando comparados com a prevalência no Brasil e em Minas Gerais (figura 11). Registrou-se que a prevalência de asma 
no Brasil e em Minas Gerais estava em queda, ao se considerar o período de 2000 a 2012, e que os valores médios anuais estaduais estiveram sempre abaixo dos nacionais. No entanto, em Ipatinga, a prevalência de asma elevou-se de 2000 a 2004, passando de 0,073 para 0,177, respectivamente. No período de 2004 a 2006 ocorreu queda nessa prevalência, que passou de 0,177 para 0,122. No entanto, a partir de 2006, as prevalências de morbidade por asma apresentaram aumentos, passando de 0,122 em 2006 para 0,175 em 2008. A partir de 2008, até 2012, é possível identificar queda, que alcança o valor de 0,093 ao final do período avaliado. Ao se comparar as prevalências de asma no Brasil, Minas Gerais e em Ipatinga no período de 2000 a 2012, apesar de Minas Gerais apresentar valores abaixo da média nacional, o mesmo não ocorreu em Ipatinga. Nesse município, as prevalências de asma só ficaram abaixo dos valores estadual e nacional no período compreendido entre 2000 e 2002. Entre 2003 a 2006, a prevalência de asma em Ipatinga apresentou-se abaixo dos valores nacionais, mas acima daqueles observados em Minas Gerais. Já entre 2007 e 2012, esses valores mantêm-se mais elevados do que aqueles registrados no país e em Minas Gerais. Apesar dos valores de prevalência mais elevados nos últimos cinco anos, é necessário registrar que a morbidade por asma está em queda no município, a partir de 2008 (figura 11) (Kashiwabara, 2016).

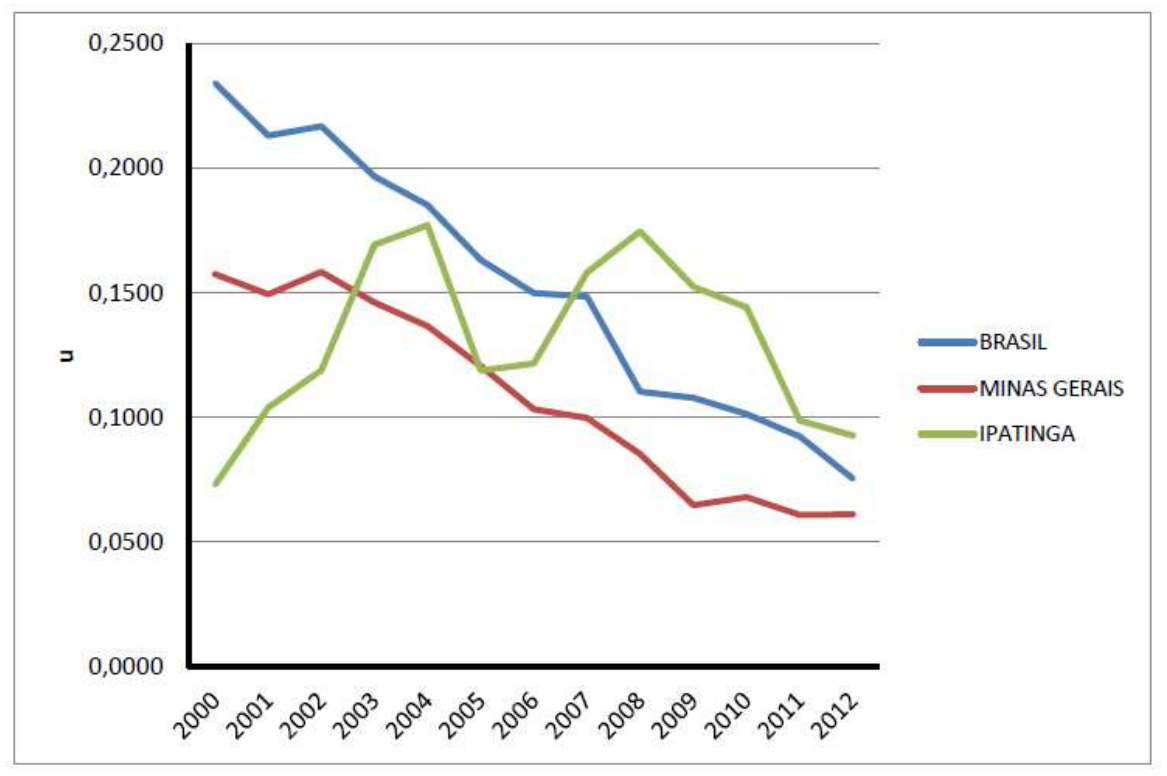

FIGURA 11 - Comparação da prevalência da asma no Brasil, Minas Gerais e Ipatinga entre os anos 2000-2012

Fonte: DATASUS, Ministério da Saúde, Brasil, 2013 
A prevalência da asma aumentou no município de Ipatinga, com valores até maiores do que o verificado nas médias do Brasil e de Minas Gerais, a partir principalmente de 2006. Considerando que a implantação do Programa Respirar ocorreu em 2003, acredita-se que esse aumento não deve estar associado ao aumento de casos, mas sim à melhoria no diagnóstico e à diminuição das subnotificações. Com a instalação do programa, a população acometida pelo agravo passou a ter maior acesso aos serviços de saúde, com profissionais qualificados e treinados para o diagnóstico, controle e tratamento da doença (Kashiwabara, 2016). Vários autores afirmam haver aumento no diagnóstico médico e na prevalência de asma em todo o mundo (Barraclough et al., 2002; Urrutia et al., 2007).

Em relação à mortalidade infantil, a segunda causa no ano de $2000 \mathrm{e}$ 2001 foi de doenças respiratórias. A presença de asma como fator determinante para a elevação da taxa de morbidade originou uma preocupação para o Serviço de Saúde Pública (SSP) do município em questão, levando à necessidade da implantação de um programa de controle e profilaxia da asma, que pretende reduzir as taxas dessa enfermidade, visando diminuição dos gastos com assistência nas emergências, hospitalizações, consultas, assim como nos custos com medicações, além da melhoria da qualidade de vida individual e familiar, com redução de sequelas emocionais e físicas (Kashiwabara, 2016).

O Programa Respirar (figura 12) teve por base a experiência do programa "Criança que Chia", desenvolvido em Belo Horizonte, Minas Gerais, que resultou em uma iniciativa bem-sucedida e de referência internacional. A assistência primária foi reorganizada, com capacitação de todos os médicos do Programa de Saúde da Família (PSF) e pediatras que atuavam na rede básica, com implantação de protocolo de diagnóstico e tratamento e acompanhamento das coordenações do programa, in loco, promovendo um nível adequado de conhecimento e atitudes para o diagnóstico, controle e prevenção da asma. Todos os profissionais das unidades de saúde foram envolvidos no programa, que contemplou a faixa etária de zero a 18 anos. A asma, então, seria abordada de forma descentralizada e competente, reduzindo seus custos tangíveis e intangíveis. Os médicos que atendiam nas unidades de urgência aos pacientes do 
SUS também foram treinados e há atualização dos protocolos e de toda a equipe a cada dois anos (Minas Gerais, 2002).

Aliado a este processo, durante a evolução do programa, os médicos do Hospital Márcio Cunha, onde é internada a maioria das crianças e adolescentes pelo Sistema Único de Saúde, também foram treinados pela mesma coordenação do Programa Respirar, no sentido de melhorar o primeiro atendimento e reduzir as complicações das exacerbações e outras morbidades concomitantes. Atualmente, programa de prevenção de asma com muita similaridade tem sido desenvolvido pelo Usisaúde, plano de saúde predominante no município (figura 12) (FSFX-Usisaúde, 2013).

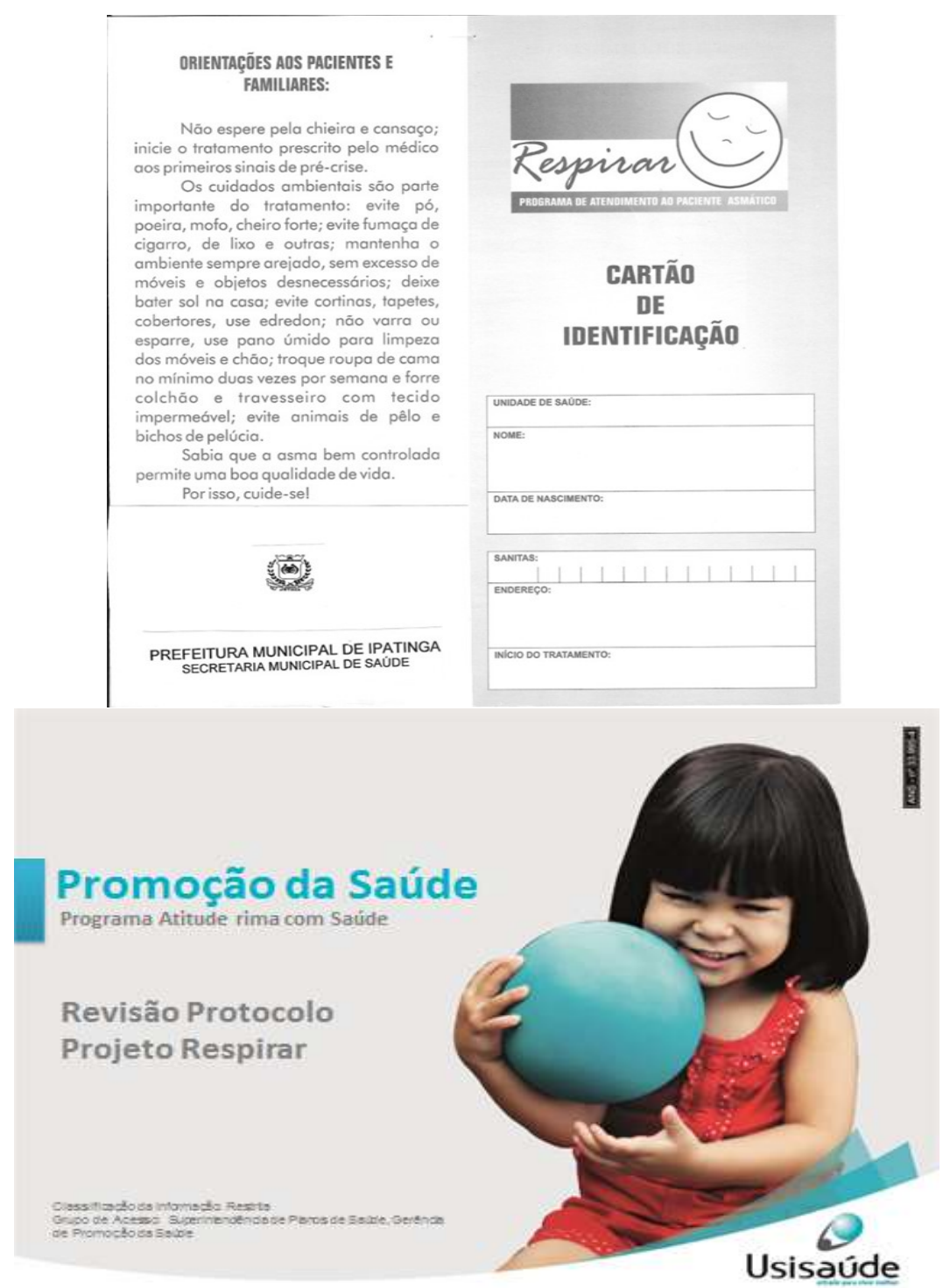

FIGURA 12 - Programas de asma de Ipatinga

Fonte: Prefeitura Municipal de Ipatinga, 2007; FSFX/Usisaúde, 2013 


\subsection{Radiação ionizante e a asma}

Muitos diagnósticos médicos por imagem dependem da utilização de raio $\mathrm{X}$, um tipo de radiação ionizante, assim como a fluoroscopia, tomografia computadorizada e imagem nuclear (Fresh, 2013).

Os pacientes com asma frequentemente são submetidos a procedimentos radiológicos, especialmente nas exacerbações, para esclarecimento diagnóstico das comorbidades e complicações.

O diagnóstico da asma é clínico, com manifestação por sintomas respiratórios recorrentes como chieira, tosse, dificuldade respiratória e aperto no peito, e o uso de raio $X$ de tórax não deve ser rotineiro, sendo reservado quando há suspeita de pneumotórax ou pneumomediastino, suspeita de pneumonia, quando a crise é muito grave com risco de vida, quando a resposta ao tratamento é insatisfatória ou quando há necessidade de ventilação assistida (Fontes et al., 2013; Britsh Thoracic Society, 2014; Grimm, 2016; SBPT, 2012).

$O$ raio $X$ de tórax tem pouco valor na crise aguda, podendo ser realizado para excluir outros diagnósticos (corpo estranho, edema pulmonar, insuficiência cardíaca), avaliar a presença de pneumomediastino (menos comum em crianças) ou detectar complicações bacterianas associadas, como pneumonia (achado infrequente em associação com exacerbações agudas da asma), conforme Cerci Neto (2007), ou no paciente asmático que, após 6 a 12 horas de tratamento intensivo, não respondeu à terapia (Fontes et al., 2013). O raio $x$ obtido durante a exacerbação da asma pode demonstrar achados normais, o que reduz sua sensibilidade como (Grimm, 2016).

A figura 13 ilustra as alterações mais frequentes encontradas na crise asmática, como a hiperinsuflação, retificação do diafragma, infiltrado perobrônquico. 


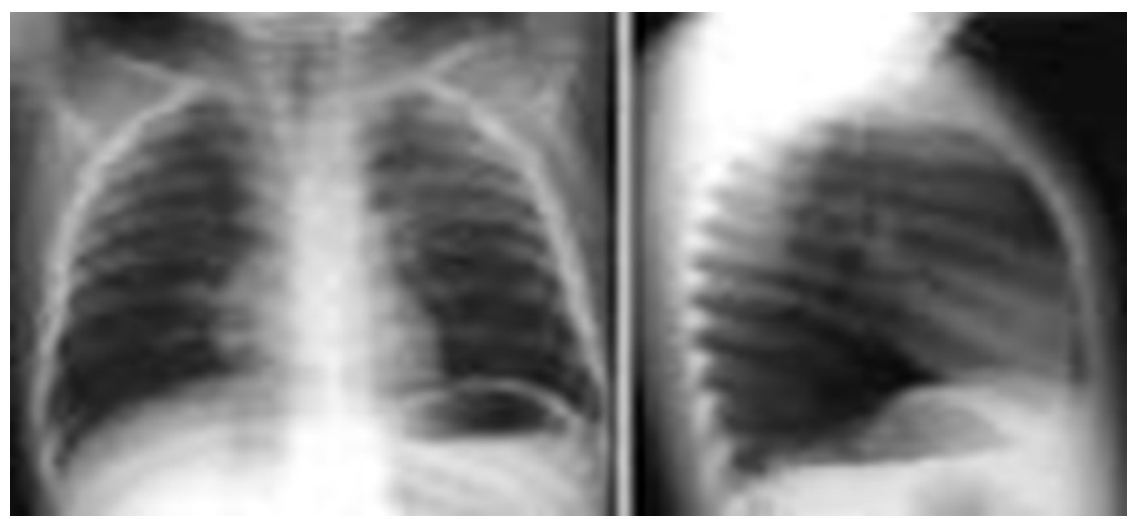

FIGURA 13 - Raio X na crise asmática Fonte: Radiopaedia.org. ${ }^{1}$

A radiografia de tórax tem papel limitado no diagnóstico da asma. É frequentemente normal (>80\%), mesmo durante a crise aguda e, quando anormal, os achados são inespecíficos, típicos da doença, já conhecidos e sem necessidade de comprovação radiológica (Telles Filho, 2017). Este exame usualmente não contribui para o manejo de crianças que apresentam bronquiolite ou asma aguda típica e eles podem levar a erros porque consolidação resultante do acúmulo de secreção é interpretada como pneumonia e pode haver uso desnecessário de antibióticos (Reed, 2008). Os achados radiológicos mais comuns na crise são os de infiltrado intersticial peribrônquico e hiperinsuflação pulmonar (Fontes et al., 2013), além de retificação do diafragma e acentuação da parede brônquica.

Segundo as diretrizes da Sociedade Brasileira de Pneumologia e Tisiologia, há orientação para que a radiografia de tórax seja indicada, na crise aguda, em casos de exacerbação grave ou suspeita de comorbidades/ complicações, tais como pneumonia, insuficiência cardíaca congestiva e pneumotórax (SBPT, 2012). As mesmas indicações são feitas por diversos outros segmentos e comprovadas por pesquisas (Grimm, 2016).

Outras evidências foram relatadas de que o uso do raio $X$ de tórax na asma, na maioria das vezes, não contribui para seu diagnóstico ou tratamento e há riscos da exposição à radiação ionizante, além do uso inapropriado de antibióticos por confusão diagnóstica com doenças virais e atelectasias (Shepherd, 2010). Ainda, reduzem a eficiência do serviço de emergência e

\footnotetext{
${ }^{1}$ Disponível em <https://radiopaedia.org/>
} 
contribuem para o alto custo do cuidado (Knapps; Simon; Sharma, 2013), e há tendência de maior realização nos serviços de urgência.

Pickup et al. (1994) efetuaram um estudo retrospectivo avaliando as manifestações radiológicas de 1.016 adultos hospitalizados com asma aguda em um período de quatro anos. As manifestações radiográficas foram classificadas em cinco grupos: (I) Normal, 536 pacientes (52,9\%); (II) Achados compatíveis com doença pulmonar obstrutiva, 323 pacientes (31,8\%); (III) Complicações de asma incluindo infecção, atelectasias, um caso de pneumomedistino e um caso de pneumotórax, 83 pacientes (8,2\%); (IV) Achados incidentais sem importância, 6 casos $(0,6 \%)$; (V) Achados incidentais importantes como tuberculose, insuficiência cardíaca, neoplasia brônquica, 68 casos $(6,7 \%)$. Concluíram que anormalidades radiológicas importantes foram encontradas em apenas $15 \%$ dos casos.

Recomendações relativas à utilização do raio $X$ no Protocolo do Instituto do Coração, Pulmão e Sangue (Heart, Lung and Blood Institute Guidelines) não mudaram desde 1991 e não fornecem recomendações sucintas para o uso de radiografias; entretanto, o desempenho de medidas e padrões de referência tem sido relatado e estudos têm demonstrado que muitas crianças com doenças respiratórias podem ser seguramente e efetivamente manejadas sem o diagnóstico por imagem (Quimonez, 2013; Knapps; Simon; Sharma, 2013).

O caminho para reduzir gastos e implementar segurança para os pacientes é eliminando práticas que não agregam benefícios. O Conselho Americano de Medicina Interna anunciou recentemente campanha para "escolha sábia”, encorajando médicos, pacientes e outros interessados em saúde para pensar e discutir sobre testes com medicamentos e procedimentos que podem ser desnecessários e uma das cinco principais recomendações é a não solicitação de raio $\mathrm{X}$ de tórax em crianças com asma e bronquiolite (Quimonez, 2013).

Os raios $X$ de cavum, seios da face e tomografia de crânio são exames também solicitados para os pacientes portadores da doença, a fim de identificar comorbidades (hipertrofia das adenoides, sinusites) ou mesmo complicações das exacerbações, muitas vezes de forma desnecessária, já que muitos desses 
diagnósticos são clínicos, como as sinusites, dispensando a investigação radiológica (Fontes, 2013).

A tomografia computadorizada do tórax de alta resolução com cortes finos (HRCT) tem permitido a visualização detalhada das vias aéreas, o que não ocorre na radiografia simples, mas raramente tem sido indicada e realizada no paciente asmático sem maior gravidade (Telles Filho, 2017).

Exposição à radiação por tomografia computadorizada está associada com pequeno, mas significante aumento de risco de câncer fatal durante a infância, e o aumento do seu uso na população pode implicar risco público futuro, justificando a defesa do cuidado com a saúde infantil e a redução inteligente da dose baseada nos princípios As Low As Reasonably Achievable (ALARA) ou "tão baixas quanto razoavelmente exequíveis", por meio de seu uso criterioso (Shah; Platt, 2008).

Os métodos de diagnóstico por imagem são parte importante da avaliação em crianças. Embora todas as modalidades disponíveis tenham sido utilizadas nestes pequenos pacientes, nos últimos anos, o destaque tem sido maior para a ultrassonografia e a tomografia computadorizada. Desde a sua introdução na prática clínica, a tomografia computadorizada tem sido utilizada, e em crianças, seu uso é cada vez mais frequente devido às vantagens em relação aos métodos para o diagnóstico e acompanhamento de várias doenças. Tem, ainda, a capacidade de evidenciar detalhes de massas, suas relações com órgãos ou invasão de estruturas adjacentes, caracterização tecidual e a detecção de metástases. Com este aumento, surgiu a necessidade da criação de protocolos que determinem redução da dose de radiação, sem comprometer a qualidade do exame. O aumento da utilização dos métodos de diagnóstico por imagem que fazem uso de radiação ionizante e, especialmente, da tomografia computadorizada é responsável pelo acentuado aumento da dose de radiação média individual por ano. Atualmente, a dose de radiação recebida por indivíduo, por ano, considerada secundária ao cuidado médico, principalmente na investigação diagnóstica de doenças, ultrapassou a dose recebida decorrente de fatores ambientais (alimentação, gás radônio e outros). Com isso, existe uma preocupação crescente da comunidade médica, das empresas produtoras de equipamentos e mesmo de pacientes em relação ao controle da dose de radiação 
determinada pelos diversos exames que utilizam radiação ionizante (Lima; Monteiro, 2011).

Estudo recente demonstrou associação significante entre o uso de tomografia de crânio e leucemia e câncer cerebral (Pearce et al., 2007). Também é de conhecimento que a radiação é cumulativa; portanto, o que está indicado fazer de imediato é agir como se essa relação fosse direta e indiscutível. Estudo coorte em mais de 175.000 pacientes até 21 anos que usaram tomografia entre 1985 e 2001 sugeriu que dose aproximada de 10mGy é suficiente para aumentar o risco de leucemia, e conclusões firmes, mesmo não sendo possíveis, suportam risco fraco (Wakeford, 2013).

O uso da tomografia computadorizada em crianças tem aumentado, consideravelmente, nos últimos anos, sendo, atualmente, o método mais utilizado na avaliação de neoplasias. Isto gera a necessidade da criação de protocolos que determinem redução da dose de radiação, sem comprometer a qualidade do exame. São fundamentais o apoio de todas as sociedades médicas e afins e a divulgação de informação adequada para a conscientização da população leiga. Muitos parâmetros técnicos ainda não são utilizados de forma padronizada nas diversas clínicas que realizam exames pediátricos (Lima; Monteiro, 2011).

Atualmente, são realizadas, por exemplo, cerca de 600.000 tomografias computadorizadas (abdome ou crânio) em menores de 15 anos nos Estados Unidos. Isto gera preocupações relacionadas a potenciais efeitos adversos. Crianças são 10 vezes mais sensíveis aos efeitos da radiação do que adultos. Acredita-se, inclusive, que o risco de uma criança morrer devido a uma neoplasia causada pela radiação seja de 1:550, no caso de realizar uma tomografia computadorizada de abdome, e de 1:1500 se for uma tomografia computadorizada do crânio. Aos médicos pediatras e clínicos, em geral, cabe o cuidado no entendimento para a solicitação de cada exame, suas vantagens e desvantagens, técnica de realização e cuidados na utilização da radiação ionizante. Crianças são definitivamente mais sensíveis à radiação do que adultos, e a exposição cumulativa provavelmente causará efeitos adversos (Lima; Monteiro, 2011).

Radiação, em doses relativamente elevadas, tem efeito biológico conhecido. Quase sem exceção, imagens médicas de diagnóstico usam baixos 
níveis de radiação. Crianças são mais vulneráveis que adultos e há expectativa de vida longa, na qual pode haver potencial risco de se manifestar câncer induzido por radiação. Para especialistas em imagem, a falta de familiaridade com técnicas frequentemente especiais para maximizar a qualidade da imagem e minimizar a radiação pode resultar em estudos com doses excessivas de radiação para crianças. Os riscos são especulativos e há recomendações para seu uso justificado e otimizado (Fresh, 2013).

Os limites de dose definidos pela Comissão Internacional de Proteção Radiológica (ICRP), para cada circunstância, são estabelecidos para limitar os efeitos estocásticos e evitar o aparecimento dos efeitos determinísticos da exposição à radiação. Mesmo baixas doses podem levar a dano e modificações num longo período; não causam problema imediato, pois ocorrem a nível celular, mas resultados podem ser observados depois de muitos anos (Todo; Rodrigues Junior, 2014).

A dose da radiação utilizada em diagnóstico por imagem na criança tem sido associada ao risco de desenvolvimento de câncer ao longo da vida. Os efeitos biológicos da radiação resultam em dano no DNA. Há três efeitos que preocupam os radiologistas sobre a necessidade de determinar a proteção radiológica e a dose, seguindo os princípios ALARA: efeitos hereditários, efeitos no desenvolvimento do embrião e feto e a carcinogênese, considerada a preocupação mais importante de baixas doses de radiação, com riscos de câncer fatal cerca de $5 \%$ por Sievert (Hall, 2009). Não é conhecido ao certo se essa radiação causa câncer, mas sabe-se que a criança é cerca de cinco vezes mais sensível que o adulto e o uso da radiação com propósitos diagnósticos tem aumentado muito nos últimos anos, especialmente a tomografia computadorizada (Pearce et al., 2007).

A menção da palavra "radiação", frequentemente, evoca algum tipo de ansiedade em pacientes, familiares e mesmo em profissionais da área de saúde. A radiação é percebida como um risco único. Essa percepção tem muitas fontes, incluindo a qualidade da informação para o público em geral sobre as lesões de radiação real ou o medo de armas ou acidentes nucleares, tais como em Chernobyl e, mais recentemente, Fukushima, no Japão. O medo resultante desses eventos deve ser reconhecido e devidamente esclarecido quando da 
utilização de exames de imagem para fins diagnósticos ou terapêuticos que utilizam radiação ionizante. Por outro lado, com a incorporação de inovações tecnológicas há uma tendência de ocorrer um grande aumento no uso de radiação médica, a maioria atribuída aos novos equipamentos multidetectores de tomografia computadorizada (Lima; Monteiro, 2011).

Muitos estudos de radiação para o tratamento de doenças benignas e alguns estudos de exposição à radiação diagnóstica têm dado grande parte da informação sobre o risco de câncer relacionado à radiação em crianças. Embora a maioria dos cânceres possa ser induzida por radiação, esses estudos demonstram riscos aumentados relacionados à dose de câncer de tireoide, seios e cérebro, câncer de pele não melanoma e leucemia. Os riscos foram relacionados à dose de radiação e pareciam ser maiores para crianças irradiadas no início da vida, e os riscos para tumores sólidos persistiram ao longo da vida (Kleinerman, 2006).

Muitos poucos estudos avaliaram o risco de câncer após a exposição à radiação diagnóstica em crianças. Embora a dose de radiação para um único procedimento possa ser baixa, os pacientes pediátricos frequentemente recebem exames repetidos ao longo do tempo para avaliar suas condições, o que pode resultar em doses cumulativas relativamente altas (Kleinerman, 2006).

Além da proteção radiológica ocupacional, a prática clínica utiliza o princípio conhecido como ALARA para pautar o uso racional desta tecnologia. Considerando, especificamente, a população pediátrica, é importante salientar que as crianças têm risco acentuadamente maior de desenvolvimento de neoplasias relacionadas à radiação, comparativamente à população adulta. Esse maior risco é explicado pela presença de maior população de células sofrendo divisões nos diversos tecidos e órgãos ainda em desenvolvimento e pela maior expectativa de vida em termos absolutos e relativos. Como exemplo, uma criança de um ano de vida tem de 10 a 15 vezes maior risco de desenvolver uma neoplasia maligna do que um adulto de 50 anos de idade para a mesma dose de radiação. Por esses motivos, há uma preocupação crescente quanto à dose de radiação utilizada nos exames radiológicos pediátricos e, em especial, nos exames de tomografia computadorizada, com vários trabalhos direcionados para 
esse tópico abordando ações para redução das doses utilizadas (Lima; Monteiro, 2011).

O princípio ALARA tem sido usado na comunidade americana há alguns anos. Entretanto o Food and Drug Administration (FDA) tem estabelecido três importantes critérios no sentido de minimizar a dose de radiação em exames de tomografia computadorizada em criança: otimizar os parâmetros técnicos, reduzir o número de fases contrastadas e reduzir a solicitações por meio da aplicação de indicações precisas ou a substituição, quando possível, por métodos que não usem radiação ionizante (Lima; Monteiro, 2011).

Juntamente com o crescente uso e complexidade destes procedimentos, vem a preocupação sobre os efeitos tardios do aumento da radiação ionizante exposta às crianças. Além dos estudos sobre sobreviventes de bomba atômica japonesa, que forneceram uma riqueza de dados sobre os riscos de câncer relacionados à radiação, inúmeros estudos epidemiológicos da exposição infantil à radiação (raios $\mathrm{X}$ e raios gama) para o tratamento de doenças benignas demonstraram aumento do câncer. Esses estudos foram amplamente revisados recentemente no relatório BEIR VII, "Riscos para a saúde decorrentes da exposição a baixos níveis de radiação ionizante", que concluiu que os dados biológicos e biofísicos disponíveis suportam um "Linear-No-Threshold" (LNT) ou Hipótese Linear (Kleinerman, 2006), cujo princípio estabelece que cada dose de radiação, de qualquer magnitude, pode produzir algum nível de efeito prejudicial que pode se manifestar como um risco aumentado de mutações genéticas.

A partir da evidência coletiva de suposições feitas sobre o risco de leucemia infantil induzido por radiação, pode-se concluir que os fins de proteção radiológica são amplamente corretos (Wakeford, 2013).

Esforços devem ser desenvolvidos pelos serviços de um modo geral no sentido da não utilização, na população pediátrica, de parâmetros automaticamente previstos para adultos, prática ainda comum nos dias atuais (Kim; Newman, 2010). Radiologistas pediátricos e radiologistas gerais, que realizam exames em pacientes pediátricos, devem fazê-lo se realmente forem necessários e, se preciso for, devem entrar em contato com os médicos solicitantes para confirmação da real importância de alguns exames. Estes devem ser realizados racionalmente, com o menor número possível de exposições e com 
a menor técnica que permita a aquisição de imagens diagnósticas. É papel do radiologista, também, orientar e estimular os técnicos e tecnólogos de radiologia para que irradiem menos as crianças (Lima; Monteiro, 2011).

O que acontece, tanto no Brasil como em outras localidades, é que muitas crianças são examinadas por radiologistas que não têm o treinamento especializado em radiologia pediátrica. Outro foco da campanha mundial é a família. Os pais devem ser informados sobre os riscos envolvidos. Para atender a todos esses segmentos, a campanha desenvolveu informativos impressos, além de disponibilizar na internet (www.imagegently.org) o protocolo ALARA, que estabelece protocolos de exames. Campanhas como o Image Gently são extremamente úteis e importantes para que o objetivo principal, que é proteger a população pediátrica, seja alcançado (Lima; Monteiro, 2011).

"Image Gently" é uma campanha educativa traduzida como "Imagem segura de alta qualidade em todos os métodos de diagnóstico por imagem que utilizam radiação ionizante na população pediátrica". Esta campanha foi criada, em 2008, pela Alliance for Radiation Safety in Pediatric Imaging, cujo objetivo principal foi a orientação e conscientização dos profissionais de saúde que atuam em radiologia pediátrica, quer sejam os médicos pediatras ou os médicos radiologistas, para que possam solicitar os exames de forma adequada, bem como realizar os exames utilizando a menor dose de radiação possível e que seja suficiente para prover imagem de alta qualidade com resolução diagnóstica. Essa campanha, inicialmente focada no uso da tomografia computadorizada, foi ampliada e hoje conta com orientações para todos os métodos de diagnóstico por imagem utilizados na população pediátrica. Entre as instituições envolvidas estão a Radiological Society of North America (RSNA), Society of Pediatric Radiology (SPR) e American Academy of Pediatrics (AAP). O Colégio Brasileiro de Radiologia também apoia e incentiva a campanha ionizante (figura 14) (Lima; Monteiro, 2011).

\section{image gently $^{\circledR}$}

FIGURA 14 - Campanha Image Gently Fonte: www.imagegently.org

The Image Gently Alliance 
Os tópicos principais do Image Gently são: padronização e controle da indicação correta dos exames de tomografia computadorizada e de raio $X$, realização destes exames com as menores doses de radiação possíveis, adequação das técnicas desses exames aos pacientes pediátricos e às indicações diagnósticas e obtenção do apoio das empresas que desenvolvem os equipamentos radiológicos para que exista uma padronização das medidas de radiação. Os pediatras e demais médicos que solicitam exames de imagem também devem ser conscientizados da importância da solicitação de exames que utilizam radiação ionizante apenas em casos realmente necessários. Neste aspecto, o Image Gently também tem um importante papel e deve ser difundido entre todos. Essa campanha é não somente "gentil", mas conclama os colegas a uma mudança de conduta no que diz respeito ao cuidado com a radiação utilizada no paciente pediátrico (Lima; Monteiro, 2011).

De modo geral, as principais diretrizes são, segundo Lima; Monteiro (2011):

- Utilizar radiação ionizante apenas quando há um benefício diagnóstico bem estabelecido;

- Usar a menor quantidade de radiação para a obtenção da melhor qualidade de imagem, atendendo às normas internacionais da boa prática;

- Utilizar outros métodos diagnósticos em imagem, como a ultrassonografia (US) ou a ressonância magnética (RM), quando aplicáveis e possíveis;

- Estudar somente a área de interesse;

- Evitar múltiplos exames radiológicos de investigação não direcionada;

- Incentivar o controle da exposição da radiação por meio da personalização e do uso de dosímetros na infância;

- Incentivar os pais e famílias no cuidado no armazenamento dos exames, com o objetivo de evitar a repetição.

A utilização da radiologia digital e de Sistema de Comunicação e Arquivamento de Imagens (PACS) contribui, ativamente, para a redução do número de exames na infância, pois os exames e seus respectivos relatórios ficam armazenados em arquivos virtuais digitais para a reutilização sempre que necessário. Por outro lado, as empresas de equipamentos estão trabalhando para 
- desenvolvimento de soluções que, durante cada exame, calculem imediatamente a carga da exposição à radiação, informando ao radiologista o cuidado imediato que deve ser efetivado no que tange à proteção radiológica (Lima; Monteiro, 2011).

São fundamentais o apoio de todas as sociedades médicas e afins e a divulgação de informação adequada para a conscientização da população leiga que pode contribuir, também, na guarda dos exames radiológicos prévios e na informação ao médico solicitante das datas e exames anteriores, realizados pelas crianças e adolescentes a cada nova consulta (Lima; Monteiro, 2011). 


\section{MATERIAIS E MÉTODOS}

\subsection{Aspectos éticos}

A pesquisa foi aprovada pelo Comitê de Ética da Unileste-MG (CAAE 42498-15.0.000.5095) em 26/05/2015 e autorizada na plataforma Brasil.

\subsection{Delineamento do estudo}

Tratou-se de estudo retrospectivo com caso controle.

Considerou-se uma população total de 746 pacientes de zero a 18 anos e que participavam do Programa Respirar, para prevenção da asma, da Prefeitura Municipal de Ipatinga, MG, no ano de 2014, com atendimentos pelo Sistema Único de Saúde (SUS) em nove das 20 Unidades Básicas de Saúde (UBS) e unidades do Programa de Saúde da Família (PSF), definidos por amostra estatística relevante e definida aleatoriamente, para um nível de confiança de $95 \%$ e uma margem de erro de $5 \%$, sendo estimada uma amostra de aproximadamente 254 pacientes. $O$ cálculo do tamanho amostral foi realizado por meio do programa Open Epi versão 3.03 (Openepi Menu, 2014).

A fórmula utilizada no cálculo amostral encontra-se no ANEXO A. Foram estimadas $30 \%$ de possíveis perdas de acompanhamento, que foram acrescidas a esse valor, resultando em uma amostra final de 363 pacientes.

A amostra foi estratificada e proporcional, considerando como estratos as equipes de saúde de cada unidade ou da unidade de saúde quando essa não era subdivida em equipes. A amostra foi proporcional ao tamanho do estrato. Dentro de cada equipe, os pacientes considerados controlados foram selecionados por amostragem aleatória simples, a partir da listagem do seu cadastro, considerados os critérios de inclusão e exclusão. Foram incluídos os participantes ativos no Programa Respirar durante todo o ano de 2014, na faixa etária de zero a 18 anos, considerados aderidos ao plano de tratamento estabelecido para o controle da asma, além de estarem participando do programa há um ano ou mais e sem outras doenças crônicas. Os pacientes que participam do Programa Respirar foram selecionados considerando sua participação efetiva 
ou adesão ao plano de tratamento, ou seja, aqueles que estivessem em uso regular da medicação de controle, que tinha bom entendimento do manejo de sua doença, técnica inalatória correta e que implementaram cuidados ambientais adequados.

Grupo controle, de zero a 18 anos, foi definido aleatoriamente nas mesmas microáreas das unidades de saúde relacionadas e contou com o igual número de crianças e adolescentes, com mesma faixa etária e sexo entre os dois grupos, de forma relativamente pareada, e não tinham diagnóstico de asma, nem outra doença crônica. O grupo controle foi selecionado no momento de consulta com o médico da unidade de saúde, quando houve procura espontânea pelo atendimento.

Foram excluídos os pacientes não aderidos ao plano de tratamento do Programa Respirar ou que tinham outras doenças crônicas, tanto os participantes do programa quanto os do grupo controle.

Tratou-se de um estudo caso-controle, para cada caso foi selecionado um controle, totalizando uma amostra final de 726 crianças e adolescentes.

As unidades de saúde selecionadas para o estudo também foram escolhidas aleatoriamente.

\subsection{Obtenção de dados e instrumentos}

Consulta prévia foi realizada nas unidades técnicas de informática da Prefeitura Municipal de Ipatinga e do Hospital Márcio Cunha quanto à disponibilidade das informações necessárias em seu sistema informatizado, com a confirmação por ambas as instituições.

Após explanação e aceite para colaboração da seleção amostral, os médicos e enfermeiros das unidades de saúde definidas identificaram os pacientes do grupo respirar e do grupo controle que preenchiam os critérios de inclusão e exclusão. Os dados solicitados incluíram: nome completo, data do nascimento, sexo, unidade de saúde, equipe e data de início no Programa Respirar, este último apenas para os pacientes do grupo respirar.

A busca das informações selecionadas (APÊNDICE A) foi realizada no sistema informatizado da Secretaria Municipal de Saúde (SANITAS) e do Hospital Márcio Cunha (HOSIX), instituições responsáveis pela totalidade dos 
atendimentos ao SUS no município de Ipatinga. A pesquisa buscou os dados com o nome do paciente e/ou com seu número de identificação, além de confirmar pela data de nascimento. Os dados coletados identificaram o número de raios $\mathrm{X}$ realizados no ano de 2014, outros exames com exposição à radiação ionizante feitos no mesmo ano, local de realização dos exames (internação, pronto atendimento ou ambulatório) e a descrição do laudo quando disponível, não havendo entrevista com os pacientes.

O Comitê de Ética em Pesquisa dispensou o TCLE (Termo de Consentimento Livre Esclarecido), considerando as justificativas apresentadas (APÊNDICE B).

Os dados foram coletados entre 2015 e 2016.

\subsection{Descrição da amostra}

A amostra entre casos e controles foi feita de forma pareada e emparelhada.

A tabela 1 esclarece a distribuição do número de pacientes do grupo respirar por unidade de saúde (US) e relaciona as unidades de saúde, equipes e número relacionado de pacientes que fizeram a composição da amostra.

O grupo controle foi selecionado com igual distribuição e número de participantes, totalizando uma amostra final de 726 crianças.

TABELA 1 - Distribuição do número de pacientes por US e equipe

\begin{tabular}{lcccc}
\hline Unidade de Saúde & Equipe & Pacientes & Percentual & Amostra \\
\hline Vila Celeste & Azul & 19 & $2,5 \%$ & 9 \\
Vila Celeste & Laranja & 38 & $5,1 \%$ & 18 \\
Vila Celeste & Verde & 7 & $0,9 \%$ & 3 \\
Vila Celeste & Branca & 11 & $1,5 \%$ & 5 \\
Vila Formosa & Única & 37 & $5,0 \%$ & 18 \\
Vila Militar & Azul & 25 & $3,4 \%$ & 12 \\
Vila Militar & Laranja & 10 & $1,3 \%$ & 5 \\
Vila Militar & Verde & 24 & $3,2 \%$ & 12 \\
Vila Militar & Vermelha & 15 & $2,0 \%$ & 7 \\
Veneza & Pacs 1 & 37 & $5,0 \%$ & 18 \\
Veneza & Pacs 3 & 25 & $3,4 \%$ & 12 \\
Veneza & Laranja & 22 & $2,9 \%$ & 11 \\
Veneza & Pacs 2 & 14 & $1,9 \%$ & 7 \\
UISA & Única & 59 & $7,9 \%$ & 29
\end{tabular}


Cont. TABELA 1

\begin{tabular}{lcccc}
\hline Unidade de Saúde & Equipe & Pacientes & Percentual & Amostra \\
\hline Panorama & Única & 141 & $18,9 \%$ & 69 \\
Canaã & Única & 85 & $11,4 \%$ & 41 \\
Limoeiro & Azul & 20 & $2,7 \%$ & 10 \\
Limoeiro & Laranja & 21 & $2,8 \%$ & 10 \\
Limoeiro & Verde & 24 & $3,2 \%$ & 12 \\
Bom Jardim & Azul & 44 & $5,9 \%$ & 21 \\
Bom Jardim & Laranja & 39 & $5,2 \%$ & 19 \\
Bom Jardim & Verde & 29 & $3,9 \%$ & 14 \\
\hline Total & & 726 & $100,0 \%$ & 363 \\
\hline
\end{tabular}

\subsection{Tratamento dos dados}

Inicialmente foi realizada uma caracterização da amostra investigada no estudo por meio da criação de tabelas de frequência e cálculo de medidas de tendência central e variabilidade. Essa caraterização foi feita comparando casos e controles.

Para avaliar a existência de diferenças entre casos e controles foi realizado o teste qui-quadrado de Pearson, apropriado para comparação de proporções, ou o teste exato de Fisher, apropriado para análises de proporções com baixas frequências. Para as variáveis numéricas foi utilizado o teste não paramétrico de Mann-Whitney. Optou-se por utilizar um teste não paramétrico devido ao caráter assimétrico das variáveis analisadas (não apresentavam distribuição normal), segundo teste de normalidade de Kolmogorov-Smirnov apresentado em ANEXO B.

$\mathrm{Na}$ comparação dos exames realizados entre casos e controles também foi calculada a estimativa de Odds Ratio (OR) com respectivo Intervalo de Confiança de 95\% (IC95\%).

Para avaliar quais fatores poderiam estar associados a um maior número de exames de raios $\mathrm{X}$ realizados foi utilizado o coeficiente de correlação de Spearman com respectivo valor-p, bem como o teste de Mann-Whitney para comparação de dois grupos.

Todas as análises consideraram um nível de significância de $5 \%$ e foram realizadas no programa estatístico SPSS (Statistical Package for Social Science) versão 19.0 . 


\section{RESULTADOS}

\subsection{Caracterização da amostra}

Conforme demonstrado na tabela 2, foi caracterizada a amostra total de 726 pacientes considerando dados sociodemográficos e grupos de estudo.

De acordo com os resultados, foram avaliadas 726 crianças e adolescentes, sendo 363 do grupo respirar e mesma quantidade no grupo controle. Observou-se predominância do sexo masculino na amostra total (58,4\%) e por grupo (60,1\% no grupo respirar e $56,7 \%$ no grupo controle). A média e mediana de idade foi em torno de oito anos em ambos os grupos, sendo o mais jovem com um ano e o mais velho com 18 anos. No que se refere à faixa etária, a maior parte dos indivíduos analisados tinha entre seis e 10 anos, tanto entre os casos $(42,3 \%)$, quanto entre os controles $(41,6 \%)$.

Observa-se que a amostra seguiu o delineamento proposto com exatamente a mesma quantidade de casos e controles em cada unidade de saúde, havendo maior percentual de avaliados na unidade do Bom Jardim $(14,9 \%)$ e menor percentual $(5,0 \%)$ no centro de saúde Vila Formosa.

O tempo médio e mediano de permanência no Programa Respirar foi de quatro anos, sendo que apenas $18,2 \%$ tinham menos de dois anos no programa.

É importante ressaltar que nenhuma das características sociodemográficas apresentou diferença significativa entre casos e controles (valores$p>0,050$ ). 
TABELA 2 - Caracterização dos dados sociodemográficos

\begin{tabular}{|c|c|c|c|c|}
\hline & $\begin{array}{l}\text { Amostra total } \\
(n=726)\end{array}$ & $\begin{array}{c}\text { Respirar } \\
(n=363)\end{array}$ & $\begin{array}{c}\text { Controle } \\
(n=363)\end{array}$ & Valor-p \\
\hline \multicolumn{5}{|l|}{ Sexo n (\%) } \\
\hline Masculino & $424(58,4 \%)$ & $218(60,1 \%)$ & $206(56,7 \%)$ & \multirow[b]{2}{*}{$0,366^{*}$} \\
\hline Feminino & $302(41,6 \%)$ & $145(39,9 \%)$ & $157(43,3 \%)$ & \\
\hline \multicolumn{5}{|l|}{ Idade } \\
\hline Média \pm Desvio-padrão & $8,3 \pm 4,0$ & $8,6 \pm 4,0$ & $8,2 \pm 4,0$ & \multirow[t]{2}{*}{$0,155^{\star *}$} \\
\hline Mediana (Mínimo - Máximo) & $7,8(1-19)$ & $7,9(2-19)$ & $7,7(1-19)$ & \\
\hline \multicolumn{5}{|l|}{ Faixa etária } \\
\hline 0 a 2 anos & $40(5,5 \%)$ & $14(3,9 \%)$ & $26(7,2 \%)$ & \multirow[t]{4}{*}{$0,170^{*}$} \\
\hline 3 a 5 anos & $198(27,3 \%)$ & $96(26,5 \%)$ & $102(28,1 \%)$ & \\
\hline 6 a 10 anos & $304(41,9 \%)$ & $153(42,3 \%)$ & $151(41,6 \%)$ & \\
\hline Mais de 10 anos & $183(25,2 \%)$ & $99(27,3 \%)$ & $84(23,1 \%)$ & \\
\hline \multicolumn{5}{|l|}{ Unidade de Saúde } \\
\hline Bom Jardim & $108(14,9 \%)$ & $54(14,9 \%)$ & $54(14,9 \%)$ & \multirow[t]{9}{*}{$0,999^{*}$} \\
\hline Canaã & $82(11,3 \%)$ & $41(11,3 \%)$ & $41(11,3 \%)$ & \\
\hline Cidade Nobre & $58(8,0 \%)$ & $29(8,0 \%)$ & $29(8,0 \%)$ & \\
\hline Jd Panorama & $140(19,3 \%)$ & $70(19,3 \%)$ & $70(19,3 \%)$ & \\
\hline Limoeiro & $64(8,8 \%)$ & & & \\
\hline Veneza & $96(13,2 \%)$ & $48(13,2 \%)$ & $48(13,2 \%)$ & \\
\hline Vila Celeste & $70(9,6 \%)$ & $35(9,6 \%)$ & $35(9,6 \%)$ & \\
\hline Vila Militar & $72(9,9 \%)$ & $36(9,9 \%)$ & $36(9,9 \%)$ & \\
\hline Vila Formosa & $36(5,0 \%)$ & $18(5,0 \%)$ & $18(5,0 \%)$ & \\
\hline \multicolumn{5}{|c|}{ Tempo no programa (em anos) } \\
\hline Média \pm Desvio-padrão & - & $4,2 \pm 4,0$ & - & \multirow[t]{2}{*}{-} \\
\hline Mediana (Mínimo - Máximo) & - & $4,0(1-14)$ & - & \\
\hline Até 2 anos & - & $66(18,2 \%)$ & - & - \\
\hline 2 a 5 anos & - & $174(47,9 \%)$ & - & \\
\hline Mais de 5 anos & - & $123(33,9 \%)$ & - & \\
\hline
\end{tabular}

\subsection{Comparação dos exames realizados entre casos e controles}

Conforme com os resultados apresentados na tabela 3, 16,9\% dos indivíduos do grupo respirar realizaram raios $X$, enquanto que no grupo controle esse percentual é de 11,3\%. Dessa forma, pode-se afirmar que uma criança do grupo respirar tem 1,59 vez mais chance de realizar um raio $X$ que aquela do grupo controle, e essa chance pode variar entre 1,04 e 2,44, sendo, portanto, uma diferença significativa.

Além disso, observou-se que dentre as crianças que realizaram raios $X$, o de seios da face e cavum foi mais frequente no grupo respirar $(15,1 \%)$ se 
comparado ao controle $(12,7 \%)$, assim como o raio $\mathrm{X}$ de tórax, que ocorreu em $51,2 \%$ das crianças do grupo respirar, contra apenas $32,2 \%$ do grupo controle. Também nesse caso a diferença entre os grupos pode ser considerada estatisticamente significativa (valor-p<0,05). A estimativa de Odds Ratio indica que uma criança do grupo respirar tem 2,6 vezes mais chance de realizar um raio $X$ dos seios da face e cavum que aquelas do grupo controle. Quando se compara ao raio $X$ de tórax, essa chance aumenta para 6,56 vezes.

No que se refere ao percentual de indivíduos que tiveram raio $X$ laudado (disponíveis somente para aqueles realizados no Hospital Márcio Cunha), não foram observadas diferenças significativas entre casos e controles (valor $p>0,05)$, sendo que dos raios $X$ realizados em ambos os grupos teve laudo.

As seguintes categorias foram consideradas para os laudos dos raios $X$ de tórax: resultado normal, resultado com alterações típicas (esperadas na crise de asma e não acrescentam mudanças no tratamento) e significativas (complicações que mudam o tratamento).

Quanto aos resultados dos exames de raios $X$ de tórax com laudo, as alterações típicas foram observadas em $70 \%$ dos indivíduos do grupo respirar que realizaram o exame, enquanto que apenas $31,6 \%$ dos controles tiveram essas alterações, e essa diferença pode ser considerada significativa (valor $-p<0,05$ ). Pode-se afirmar que crianças do grupo respirar têm 5,6 vezes mais chance de apresentar alterações típicas nos raios $X$ de tórax que as do grupo controle.

Quando se analisa apenas a ocorrência de alterações significativas em comparação aos resultados normais ou com alterações típicas, observa-se que apenas $10 \%$ dos raios $X$ de tórax com laudo entre os pacientes do grupo respirar tiveram esse tipo de alteração, contra $15,8 \%$ dos controles, sem diferença significativa entre os grupos $(p>0,05)$. Dessa forma, em $90 \%$ dos raios $X$ realizados e laudados no grupo respirar e em $84,2 \%$ do grupo controle o resultado foi normal ou com alterações típicas. 
TABELA 3 - Comparação dos exames realizados em 2014

\begin{tabular}{|c|c|c|c|c|}
\hline \multicolumn{3}{|c|}{ Grupo } & \multirow[b]{2}{*}{ Valor-p } & \multirow[b]{2}{*}{ OR [IC 95\%] } \\
\hline & $\begin{array}{c}\text { Respirar } \\
(n=363)\end{array}$ & $\begin{array}{c}\text { Controle } \\
(n=363)\end{array}$ & & \\
\hline \multicolumn{5}{|l|}{ Realizou RX } \\
\hline Não & $301(83,1 \%)$ & $321(88,7 \%)$ & \multirow{2}{*}{$0,032^{*}$} & 1,00 \\
\hline $\operatorname{Sim}$ & $61(16,9 \%)$ & $41(11,3 \%)$ & & $1,59[1,04 ; 2,44]$ \\
\hline \multicolumn{5}{|l|}{ Tipo de RX } \\
\hline Outros & $51(33,6 \%)$ & $65(55,1 \%)$ & \multirow{3}{*}{$<0,001^{*}$} & 1,00 \\
\hline Seios da face e cavum & $23(15,1 \%)$ & $15(12,7 \%)$ & & $2,61[1,53 ; 4,47]$ \\
\hline Tórax & $78(51,2 \%)$ & $38(32,2 \%)$ & & $6,56[3,43 ; 13,07]$ \\
\hline \multicolumn{5}{|l|}{$\mathrm{RX}$ tórax laudados } \\
\hline Não & $38(48,7 \%)$ & $19(50,0 \%)$ & \multirow{2}{*}{$0,897^{*}$} & 1,00 \\
\hline Sim & $40(51,3 \%)$ & $19(50,0 \%)$ & & $0,95[0,43 ; 2,08]$ \\
\hline \multicolumn{5}{|l|}{ Resultado $\mathrm{RX}$ tórax } \\
\hline Normal & $8(20,0 \%)$ & $10(52,6 \%)$ & \multirow{3}{*}{$0,017^{\star * *}$} & 1 \\
\hline Alterações típicas & $28(70,0 \%)$ & $6(31,6 \%)$ & & $5,60[1,56 ; 21,74]$ \\
\hline Alterações significativas & $4(10,0 \%)$ & $3(15,8 \%)$ & & $1,63[0,26 ; 11,13]$ \\
\hline \multicolumn{5}{|l|}{$\begin{array}{l}\text { Resultado RX tórax - } \\
\text { alterações significativas }\end{array}$} \\
\hline Não & $36(90,0 \%)$ & $16(84,2 \%)$ & \multirow{2}{*}{$0,803^{* * *}$} & 1 \\
\hline Sim & $4(10,0 \%)$ & $3(15,8 \%)$ & & $1,67[0,28 ; 9,01]$ \\
\hline
\end{tabular}

Apenas três crianças do grupo respirar $(0,9 \%)$ e uma do grupo controle $(0,3 \%)$ realizaram outros exames com radiação ionizante.

\subsection{Fatores associados ao número de exames de raios $X$ realizados}

No que se refere ao número de exames de raios $X$ realizados, demonstrado na tabela 4 , observou-se uma tendência de maior número de exames no grupo respirar, com média de 0,4 entre os casos e de 0,3 entre os controles, sendo essa diferença significativa (valor - $p<0,05$ ). A figura 15 também ilustra essa tendência. 
TABELA 4 - Descrição do número de exames de raios $X$ realizados por grupo entre crianças e adolescentes de Ipatinga, no ano de 2014

\begin{tabular}{lccc}
\hline \multicolumn{1}{c}{ Número de RX realizados } & \multicolumn{2}{c}{ Grupo } \\
& $\begin{array}{c}\text { Respirar } \\
(\mathrm{n}=363)\end{array}$ & $\begin{array}{c}\text { Controle } \\
(\mathrm{n}=363)\end{array}$ & Valor-p \\
\hline Média \pm Desvio-padrão & $0,4 \pm 1,1$ & $0,3 \pm 1,2$ & $0,035^{* *}$ \\
Mediana (Mínimo - Máximo) & $0,0(0-7)$ & $0,0(0-13)$ & \\
\hline${ }^{* *}$ Teste de Mann-Whitney & & &
\end{tabular}

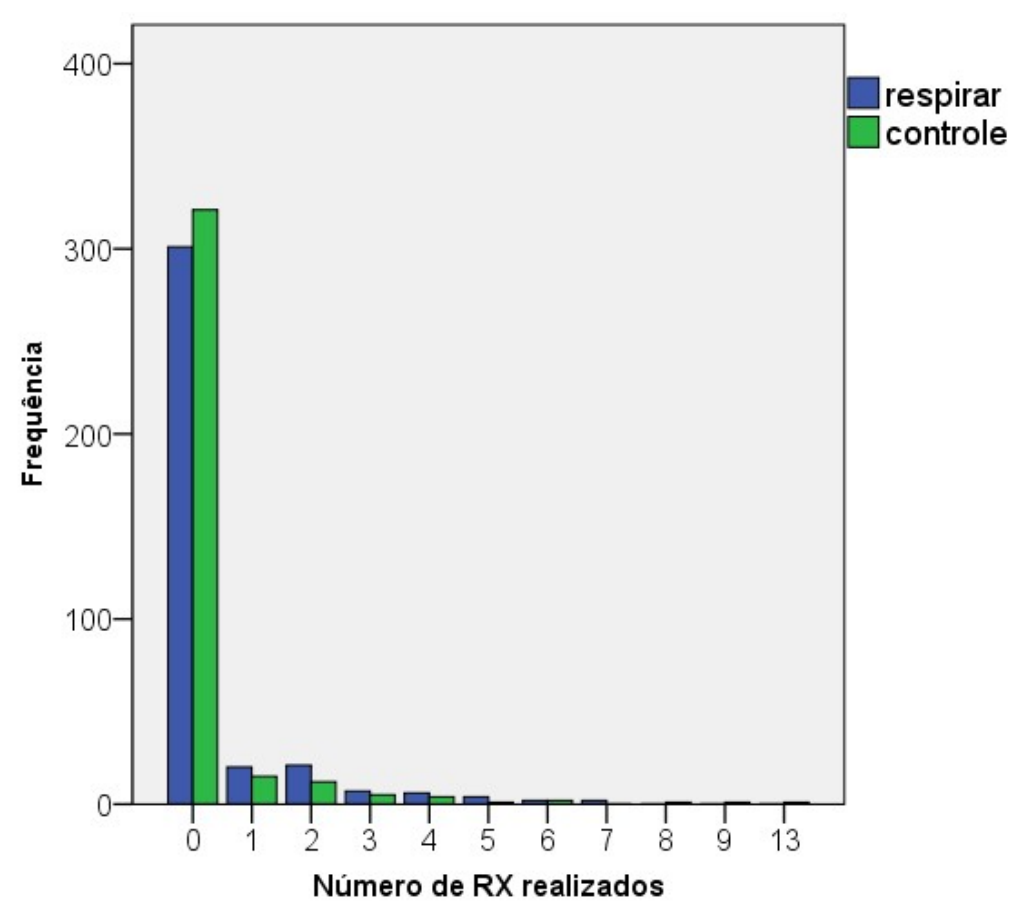

FIGURA 15 - Distribuição do número de raios $\mathrm{X}$ realizados por grupo

Foi observada uma correlação significativa (valor - $p<0,05)$ e inversa (coeficiente negativo) entre o número de raios $X$ realizados e a idade, bem como o tempo no programa, entre as crianças e adolescentes que participam do Programa Respirar, apresentados na tabela 5. Isso indica que quanto maior a idade ou o tempo de permanência no Programa Respirar menor o número de raios $x$ realizados.

Quando avaliada a correlação entre o número de raios $\mathrm{X}$ realizados e a idade no grupo controle, essa não se mostrou estatisticamente significativa (valor $-p>0,05)$. 
TABELA 5 - Correlação entre o número de raios $X(R X)$ realizados e a idade ou o tempo no Programa Respirar

\begin{tabular}{lcc}
\hline \multicolumn{1}{c}{ Número de RX realizados } & \multicolumn{2}{c}{ Coeficiente* $^{*}$ (valor-p) } \\
& Respirar & Controle \\
\hline Número de RX realizados x idade & $-0,13(0,012)$ & $-0,02(0,666)$ \\
Número de RX realizados x tempo no programa & $-0,12(0,027)$ & \\
\hline${ }^{*}$ Coeficiente de correlação de Spearma. & \multicolumn{2}{c}{}
\end{tabular}

Também foi analisado o número de exames de raios $X$ realizados de forma categorizada na tabela 6 . De acordo com os resultados, no grupo respirar $5,5 \%$ das crianças realizaram um raio $X, 9,4 \%$ realizaram de dois a quatro exames e $2,2 \%$ realizaram cinco exames ou mais. Já no grupo controle, o percentual de realização de apenas um exame foi $4,1 \%$, de dois a quatro foi $5,8 \%$ e $1,7 \%$ das crianças realizaram cinco ou mais exames de raios $X$. Dessa forma, assim como mencionado anteriormente, observa-se uma tendência a um maior número de exames entre os indivíduos do grupo respirar. Entretanto, quando analisado o número de raios $X$ categorizados, essa diferença entre os grupos não chegou a ser estatisticamente significativa (valor - $p>0,05$ ), podendo este resultado ser atribuído à estratificação da amostra.

TABELA 6 - Descrição do número de exames de raios $X(R X)$ realizados de forma categorizada por grupo entre crianças e adolescentes de Ipatinga, no ano de 2014

\begin{tabular}{lccc}
\hline \multicolumn{1}{c}{ Número de RX realizados } & $\begin{array}{c}\text { Respirar } \\
(\mathrm{n}=363)\end{array}$ & $\begin{array}{c}\text { Gontrole } \\
(\mathrm{n}=363)\end{array}$ & Valor-p \\
\hline Nenhum & $301(82,9 \%)$ & $321(88,4 \%)$ & $0,194^{*}$ \\
1 & $20(5,5 \%)$ & $15(4,1 \%)$ & \\
2 a 4 & $34(9,4 \%)$ & $21(5,8 \%)$ & \\
5 ou mais & $8(2,2 \%)$ & $6(1,7 \%)$ & \\
\hline
\end{tabular}

*Teste Qui-quadrado de Pearson

A tabela 7 demonstra os achados de comparação entre faixa etária e tempo no programa em relação ao número de raio $X$ distribuído em categorias.

$\mathrm{Na}$ comparação entre faixa etária e o número de raios $\mathrm{X}$ realizados no grupo respirar observou-se que, entre aquelas com faixa etária entre zero e dois anos, uma $(7,1 \%)$ realizou um raio $X$ no período analisado, uma $(7,1 \%)$ realizou de dois a quatro e outra criança realizou cinco ou mais $(7,1 \%)$. Já entre as crianças de três a cinco anos, $6,3 \%$ realizaram um raio $X, 15,6 \%$ realizaram de 
dois a quatro exames e 4,2\% realizaram cinco exames ou mais. Entre aquelas com idade entre seis e 10 anos, 6,5\% realizaram um raio $X, 7,2 \%$ realizaram de dois a quatro e $2,0 \%$ realizaram cinco ou mais. Por fim, entre as crianças e adolescentes com mais de 10 anos, 3,0\% realizaram um raio $X, 7,1 \%$ realizaram de dois a quatro e apenas $2,0 \%$ realizaram cinco ou mais.

No que se refere ao tempo no programa, entre aqueles com idade de dois a cinco anos, 9,1\% realizaram um exame de raio $X, 9,1 \%$ realizaram de dois a quatro exames e 1,5\% realizarou cinco exames ou mais. Já entre aqueles com mais de cinco anos no Programa Respirar, 4,1\% realizaram apenas um exame, $5,7 \%$ realizaram de dois a quatro exames e $1,6 \%$ realizou cinco ou mais.

Quando analisados os dados categorizados, não foi observada associação significativa entre faixa etária e número de raios $\mathrm{X}$ ou entre tempo no programa e número de raios $X$ (valores - $p>0,05$ ), podendo compreender que, neste caso, a amostra foi pequena devido à estratificação.

TABELA 7 - Comparação do número de exames de raios $X(R X)$ categorizados e a faixa etária ou o tempo no Programa Respirar na amostra de crianças e adolescentes do grupo respirar

\begin{tabular}{|c|c|c|c|c|c|}
\hline & \multicolumn{4}{|c|}{ Número de RX realizados } & \multirow[b]{2}{*}{ Valor-p } \\
\hline & Nenhum & 1 & 2 a 4 & $\begin{array}{l}5 \mathrm{ou} \\
\text { mais }\end{array}$ & \\
\hline \multicolumn{6}{|l|}{ Faixa etária } \\
\hline 0 a 2 anos & $11(78,6 \%)$ & $1(7,1 \%)$ & $1(7,1 \%)$ & $1(7,1 \%)$ & $0,094^{* * *}$ \\
\hline 3 a 5 anos & $71(74,0 \%)$ & $6(6,3 \%)$ & $15(15,6 \%)$ & $4(4,2 \%)$ & \\
\hline 6 a 10 anos & $131(85,6 \%)$ & $10(6,5 \%)$ & $11(7,2 \%)$ & $1(0,7 \%)$ & \\
\hline Mais de 10 anos & $87(87,9 \%)$ & $3(3,0 \%)$ & $7(7,1 \%)$ & $2(2,0 \%)$ & \\
\hline \multicolumn{6}{|c|}{$\begin{array}{l}\text { Tempo no programa em } \\
\text { faixas }\end{array}$} \\
\hline Até 2 anos & $53(80,3 \%)$ & $6(9,1 \%)$ & $6(9,1 \%)$ & $1(1,5 \%)$ & $0,363^{* * *}$ \\
\hline 2 a 5 anos & $139(79,9 \%)$ & $9(5,2 \%)$ & $21(12,1 \%)$ & $5(2,9 \%)$ & \\
\hline Mais de 5 anos & $109(88,6 \%)$ & $5(4,1 \%)$ & $7(5,7 \%)$ & $2(1,6 \%)$ & \\
\hline
\end{tabular}

Foram analisados ainda os resultados dos exames daqueles pacientes que realizaram cinco exames de raio $X$ ou mais $(n=8$ grupo respirar e $n=6$ grupo controle). Desses pacientes, para apenas quatro do grupo respirar e um do grupo controle havia laudo do exame. Dos quatro resultados laudados no grupo respirar, 
metade teve alterações típicas e metade alterações significativas. No grupo controle, o único laudo disponível revelou alteração típica no exame.

\subsection{Descrição dos locais de realização dos exames de raios $X$}

De acordo com os resultados apresentados na figura 16 , em ambos os grupos, a maioria dos exames de raios $X$ analisados foi realizada no pronto atendimento $(69,7 \%$ dos exames do grupo respirar e $82,0 \%$ do grupo controle). Para o grupo respirar, observou-se ainda $22,1 \%$ de exames fora, solicitados no ambulatório e 8,3\% na internação. Já no grupo controle, 10,9\% dos exames foram realizados na internação e $7,0 \%$ no ambulatório.

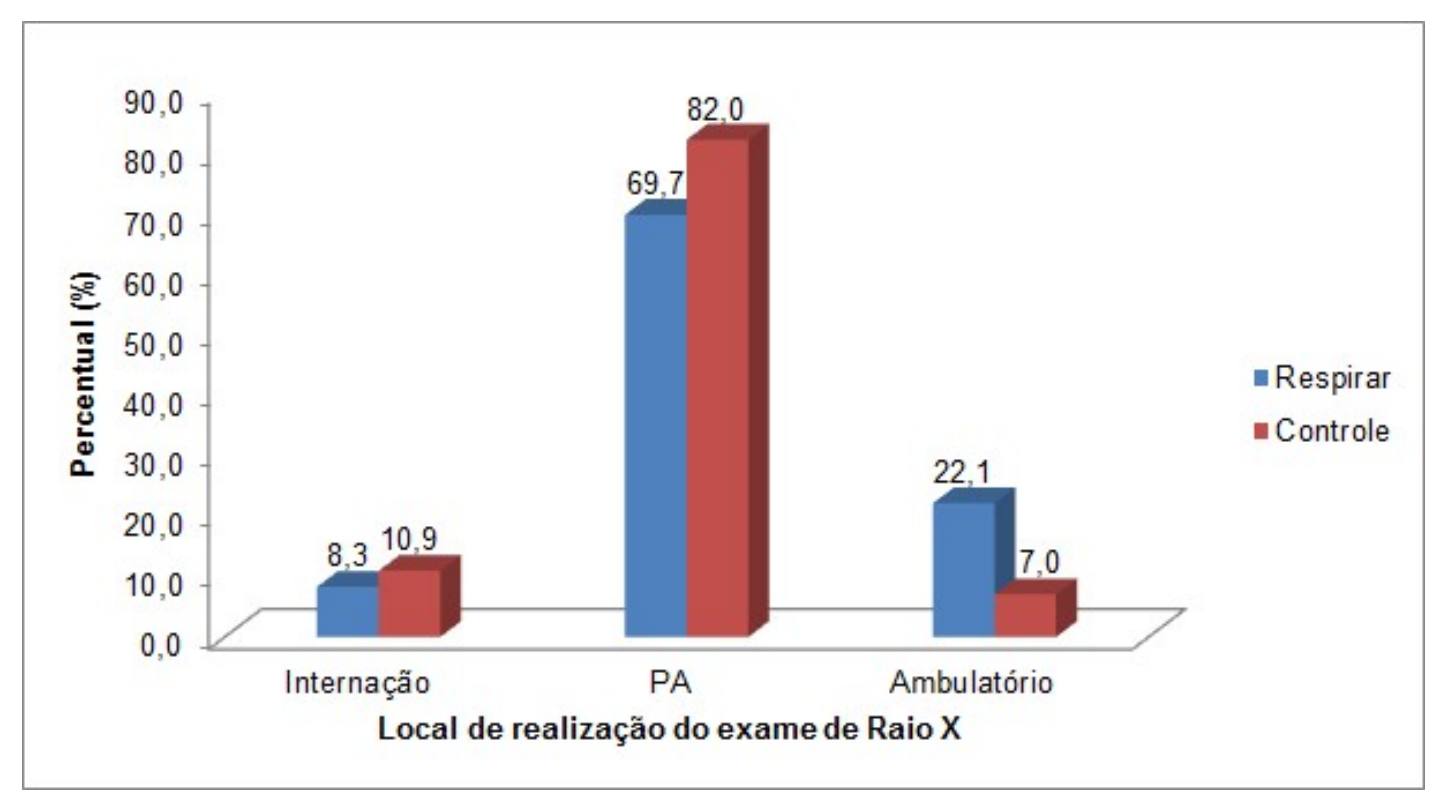

FIGURA 16 - Gráfico de setores da distribuição do local de realização dos exames de raios X por grupo 


\section{DISCUSSÃO}

O estudo, com caso controle, tem amostra abrangente e confiável, considerando que não ocorreram diferenças significativas entre casos e controles quanto às características sociodemográficas.

A amostra respirar, mesmo acompanhada em plano de cuidados, continuou tendo mais chance significativa de ser submetida à radiação ionizante propedêutica, especialmente $\mathrm{o}$ raio $\mathrm{X}$ de tórax, mas também raio $\mathrm{X}$ de cavum $\mathrm{e}$ seios da face, conforme também demonstrado por Fontes et al. (2013).

Preocupantes são algumas evidências de que, apesar de nenhuma das diretrizes apoiar a utilização do raio $\mathrm{X}$ de tórax de rotina na asma, inclusive o protocolo médico específico do Programa Respirar, há uma tendência significativa para o aumento de seu uso em crianças com visitas aos departamentos de urgência, em acordo com Knapps, Simon e Sharma (2013). Os pronto atendimentos continuam sendo o local de realização da grande maioria dos raios $\mathrm{X}$, como demonstrado em outros estudos, mas o de tórax, na asma, é desencorajado por Matheus et al. (2009), mesmo nos serviços de urgência, quando não há indícios evidentes de complicações, especialmente pneumonias. Knapps, Simon e Sharma (2013) ainda relacionam o maior número de raios $\mathrm{X}$ nos serviços de urgência com a pressão familiar sobre os plantonistas para práticas mais agressivas e ao tempo insuficiente para se dedicar ao paciente.

Grimm (2016) afirma que o valor do raio X é revelar complicações ou causas alternativas de sibilância e que é mais usado no diagnóstico inicial da asma do que nas exacerbações, embora tenha valor na exclusão de complicações nesses episódios. Também Fontes et al. (2013) recomendam o raio $\mathrm{X}$ de tórax no diagnóstico diferencial da asma, mas nas crises somente com as indicações específicas relatadas anteriormente.

Shepherd (2010) enfatiza que estudos retrospectivos demonstram que o uso do raio $X$ de tórax, na maioria das circunstâncias, não contribui para o diagnóstico e tratamento da asma aguda, devendo este ser desencorajado. 
Matheus et al. (2009) consideram que no serviço de urgência a pneumonia é incomum em crianças sibilantes e que o histórico e manifestações clínicas devem ser determinantes para indicar o raio $X$ de rotina em sibilantes sem febre.

Gentile et al. (2003) já relatavam que um em 27 raios $X$ de tórax na asma aguda encontra anormalidade significativa e sugerem o uso de critérios seguros para reduzir seu uso nas exacerbações.

Roback e Dreitlein (1998) estudaram 298 episódios de crises de broncoespasmo, sendo que 121 fizeram o exame de raio $X$ de tórax e 177 não tiveram a indicação. Dentre os exames realizados, 29 eram positivos (alterações significativas) e 92 não apresentavam alterações que influenciaram o tratamento.

Gershel et al. (1983) estudaram 375 crianças maiores de um ano no primeiro episódio e encontraram $94,3 \%$ de raios $X$ de tórax com asma não complicada (raio $X$ negativo ou com alterações chamadas típicas); 5,7\% dos exames eram positivos, com evidência de atelectasia ou pneumonia (alterações significativas), com o paciente apresentando frequência respiratória maior que 60, frequência cardíaca maior que 160, estertores localizados ou murmúrio vesicular reduzido localizado, sibilos localizados após tratamento e febre, reforçando que a avaliação clínica cuidadosa é necessária para a indicação correta do raio $X$ de tórax.

Rushton (1982) já observava que o raio $X$ de rotina não parece fornecer informações para planejar o tratamento de crianças com asma.

Tsai et al. (1993) realizaram estudo prospectivo em 128 pacientes adultos que necessitaram de internação por doença obstrutiva aguda das vias aéreas sem complicação e evidenciaram que o raio $X$ de tórax de rotina não acrescentava benefício.

As dificuldades para que as pessoas sigam as diretrizes baseadas em evidências são amplamente conhecidas, conforme Michne e Johston (2004) e Dexheimer et al. (2013) e corroboram com os achados desta pesquisa. Mesmo tendo diagnóstico já estabelecido de asma e participando de programa específico de controle de sua doença, com equipe treinada regularmente para o acompanhamento, os casos pesquisados apresentaram exacerbações que os levaram aos serviços de urgência, onde foi realizada a maioria dos exames. 
Buckmaster e Bonn (2005) analisaram a quantidade de raio $X$ de tórax realizada antes e após as orientações específicas do corpo clínico de dois hospitais, treinado segundo diretrizes e programas de educação, delineando quando o exame deveria ser considerado necessário, como paciente sabidamente asmático, diagnóstico primário da asma, quando havia melhora com o tratamento inicial instituído, quando pneumotórax não era suspeitado e se o paciente não tivesse indicação de UTI (Unidade de Terapia Intensiva). Doze meses antes do programa de educação, $81,1 \%$ dos raios $\mathrm{X}$ de tórax foram considerados desnecessários, e seis meses após a educação, 78\% ainda eram desnecessários. Em acordo, Dexheimer et al. (2013) afirmaram que as diretrizes de asma são destinadas a orientar decisões de tratamento, mas sua aderência é inadequada.

Mesmo assim, há incentivo à utilização de protocolos para muitas patologias, inclusive a asma, tendo como exemplo mais evidente o Global Iniciative for Asthma (GINA, 2016), atualizado a cada dois anos e que orienta as melhores práticas para o diagnóstico, tratamento e controle da doença, assim como recomendado por Gildenhuys, Lee e Isbister (2009). Segundo Michne e Johston (2004), as diretrizes concretas e precisas têm mais chance de serem seguidas do que quando vagas e não específicas, e afirmam que existe ampla evidência para sustentar o argumento de que a intervenção mais simples e eficaz, em termos de custos para a implementação de diretrizes, é reescrevê-las em termos comportamentais específicos, com base em uma análise de antecedentes e das consequências que controlam o comportamento de implementações.

A maioria dos pacientes do grupo respirar teve laudo de raio $X$ de tórax normal ou com alterações típicas, possibilitando o questionamento a respeito da indicação do exame, mesmo em equipe treinada, assim como observado por Knapps, Simon e Sharma (2013), Buckmaster e Boon (2005), Roback e Dreitlein (1998), Shah e Platt (2008), Gershel et al. (1983) e Pickup, Nee e Randall (1994), confirmando que é necessária a avaliação clínica cuidadosa para a indicação precisa do exame e confirmando, assim como Grimm (2016), que o raio X de tórax tem pouca sensibilidade diagnóstica, ou seja, o exame pode se apresentar normal ou com alterações já esperadas, sem influenciar o tratamento; além disso, o exame tem especificidade limitada na asma, considerando que outras doenças, como pneumonias virais, podem apresentar alterações semelhantes. 
Embora tenha sido observado de forma menos enfática, mas significativa, os exames com resultados normais ou com alterações típicas ocorreram também no grupo controle, concluindo sobre a necessidade de ampliar o conceito ALARA, limitando os estudos àqueles que contribuem para o manejo do paciente, como orientado por Reed (2008), e confirmam, como Hall (2009), que a defesa do cuidado com a saúde infantil implica promover a redução inteligente da dose, minimizando práticas que não agregam benefícios. Como concluíram Buckmaster e Boon (2005), há necessidade de pesquisas para quantificar e então reduzir o número de raios $X$ desnecessários sendo feito em crianças com asma.

Observa-se que quantidade bastante expressiva de raios $X$ foi realizada no ambulatório. Mesmo com as indicações de raios $X$ sendo referenciadas para diagnóstico diferencial, conforme Fontes et al. (2013), as crianças avaliadas tinham como critério de inclusão estarem participando há mais de um ano do Programa Respirar, já tinham o diagnóstico de asma estabelecido e, portanto, não contemplavam esta indicação.

Mesmo com todas as evidências anteriores, não pode-se deixar de observar que a grande maioria dos pacientes do grupo respirar, assim como do grupo controle, não foi submetida a nenhum raio X durante o ano de 2014 (83,1\% e $88,7 \%$, respectivamente), cabendo a discussão de que os programas de asma, a educação continuada das equipes médicas e o uso de protocolos podem reduzir não somente as internações e visitas à urgência, conforme demonstrado por Fontes (2011), mas também o uso propedêutico de exames que envolvem radiação ionizante, além dos custos do tratamento. Fontes (2011) ainda conclui que, diante da alta prevalência da asma e da limitada implantação de consensos, demonstrar o impacto de um programa de asma é de interesse social.

Assim como citado por Telles Filho (2017), não foram indicadas tomografias relacionadas nos pacientes pesquisados, corroborando as indicações em protocolos neste caso. 


\section{CONCLUSÕES E CONSIDERAÇÕES FINAIS}

O trabalho mostrou que os pacientes com asma apresentam maior risco de serem submetidos ao raio $X$ em comparação aos que não apresentam doença crônica, mas que o controle da doença por meio de programas específicos pode minimizar a exposição.

A maioria dos raios $\mathrm{X}$ de tórax foi solicitada nas visitas aos serviços de urgência, mas apenas $10 \%$ deles apresentavam alterações significativas no grupo de asmáticos, demonstrando as dificuldades na prossecução das melhores práticas orientadas em protocolos e diretrizes. Este resultado é preocupante, ao considerar-se que crianças têm risco aumentado de desenvolver câncer quando comparadas aos adultos, quando expostas à radiação ionizante, especialmente se levar-se em conta que elas têm expectativa de vida longa e maior chance de expressar o risco.

Diante dos resultados, algumas propostas para estudo futuro podem auxiliar e reduzir a realização de exames que envolvem a radiação ionizante de forma desnecessária e seus riscos, além dos custos da saúde.

Assim, propõe-se enfatizar o uso racional dos exames que envolvem radiação ionizante nos pacientes com asma, com adequações no protocolo médico e maior treinamento das equipes, já que existe ampla evidência para sustentar o argumento de que a intervenção mais simples e eficaz para a implementação de diretrizes é reescrevê-las em bases comportamentais.

Sugere-se aprimorar o treinamento da equipe médica dos serviços de urgência, considerando ser o local de maior número de solicitação dos exames, em acordo com vários estudos relacionados citados na discussão. $O$ treinamento também deverá ser aprimorado no atendimento primário, considerando o número expressivo de exames realizados no ambulatório.

Orienta-se criar informe no documento de identificação do paciente com asma para registro da realização de raios $X$ e resultados, chamando atenção 
para o excesso de exames ou mesmo para resultados sem alterações significativas recentes ou informações já evidenciadas anteriormente.

Propõe-se melhorar a adesão e controle dos pacientes asmáticos para reduzir as exacerbações, períodos de maior risco na realização desnecessária de exames que envolvem a radiação ionizante, estimulando as equipes a ações específicas e acompanhamento rigoroso, previsto no plano de cuidados da doença.

Preconiza-se disseminar para toda a classe médica os princípios ALARA.

Recomenda-se, ainda, promover maior envolvimento das equipes, justificando que o impacto positivo do programa, em todos os níveis de abordagem, é de interesse social. 


\section{ANEXOS}

ANEXO A - Fórmula utilizada para o cálculo amostral

Para o cálculo do tamanho amostral, o programa utiliza a seguinte equação:

$$
\begin{aligned}
& n=[N p(1-p)] /\left[\left(d^{2} / Z^{2}{ }_{1-\alpha / 2}{ }^{*}(N-1)+p^{*}(1-p)\right]\right. \\
& \text { onde } N=\text { tamanho da população }(N=746) \\
& p=\text { proporção estimada para o evento }(p=50 \%) \\
& d=\text { margem de erro }(d=5 \%) \\
& 1-\alpha / 2=\text { nível de confiança }(95 \%)
\end{aligned}
$$


ANEXO B - Resultados do teste de normalidade para as variáveis numéricas

\begin{tabular}{|l|l|l|l|}
\hline \multirow{2}{*}{} & \multicolumn{3}{|l|}{ Kolmogorov-Smirnov } \\
\cline { 2 - 4 } & Estatística & GI & Valor-p \\
\hline Idade &, 071 & 725 &, 000 \\
\hline
\end{tabular}

\begin{tabular}{|l|l|l|l|}
\hline \multirow{2}{*}{} & \multicolumn{3}{|l|}{ Kolmogorov-Smirnov } \\
\cline { 2 - 4 } & Estatística & GI & Valor-p \\
\hline $\begin{array}{l}\text { Número } \\
\text { RX }\end{array}$ &, 480 & 726 &, 000 \\
\hline
\end{tabular}

As variáveis numéricas idade e número de $\mathrm{RX}$ realizados não apresentaram distribuição normal (valores- $p<0,05)$. 


\section{APÊNDICES}

APÊNDICE A - Formulário de coleta de dados

\begin{tabular}{|l|l|}
\hline Paciente & \\
\hline Data de nascimento & \\
\hline Gênero & \\
\hline Unidade de saúde / equipe & \\
\hline $\begin{array}{l}\text { Início no programa respirar (somente } \\
\text { Grupo Respirar) }\end{array}$ & \\
\hline Número de raios X realizados em 2014 & \\
\hline Outros exames com radiação ionizante & \\
\hline Local (internação / PA / ambulatório) & \\
\hline Descrição dos laudos & \\
\hline
\end{tabular}




\section{APÊNDICE B - Termo de Consentimento Livre e Esclarecido}

\section{Justificativa de Dispensa}

Entendemos a importância do respeito à dignidade humana e a importância de que toda pesquisa, sempre que possível, se processe com consentimento livre e esclarecido (TCLE) dos participantes. Entretanto, para a execução deste projeto, sua obtenção inviabilizará a pesquisa, pelos motivos a seguir:

- Os responsáveis pelo banco de dados autorizaram a coleta das informações presentes nos bancos, mas não permitirão o contato com os pacientes;

- Há dificuldade de acesso aos pacientes para a obtenção do TCLE, tendo em vista que o grupo controle, em especial, não se sentiria atraído para esta avaliação, considerando-se que são saudáveis;

- Os participantes das amostras podem não compreender o real objetivo da pesquisa e, desta forma, se preocupar demasiadamente a respeito do seu diagnóstico e condição clínica por submissão à radiação ionizante, o que seria prejudicial à sua saúde;

- Alguns pacientes já mudaram ou não participam mais do programa ou mesmo do grupo controle atualmente.

O pesquisador terá acesso aos dados da propedêutica radiológica realizada no ano de 2014 por meio do sistema informatizado específico para esses dados e somente coletará os dados necessários, sem conter informações adicionais, sem contato com o prontuário do paciente. Somente serão usados dados que se referem ao estudo do uso da radiação ionizante: idade, sexo, unidade de saúde e equipe, número de exames radiológicos realizados, onde foram realizados os exames (ambulatório, internação e serviço de urgência) e seus resultados. 
Em nosso entendimento, a não obtenção do TCLE não comprometerá a saúde do participante, não traz riscos substanciais à privacidade $\mathrm{e}$ confidencialidade dos dados dos participantes ou aos vínculos de confiança com o pesquisador, além de a pesquisa ser realizada somente pelo pesquisador, tendo apenas a participação dos médicos das unidades de saúde para seleção da amostra, todos regidos pelos princípios do sigilo, inerente à profissão.

Como mencionado no corpo do texto, a pesquisa permitirá conhecer a população assistida pelo Programa Respirar, oportunizando detectar pontos de fragilidade no programa e, com isso, favorecer a adoção de medidas com vistas a melhorar a qualidade do diagnóstico, prognóstico e tratamento, por meio de intervenções nos aspectos relacionados aos pacientes e serviços prestados pelo município.

Ainda podemos ressaltar os claros benefícios. Conforme revisão da literatura, a aplicação dos princípios ALARA e a evidência de que pacientes com asma controlada devem ter mínimas complicações de sua doença e assim fazer menos exames que usam a radiação ionizante, a realização de exames que envovem a exposição à radiação ionizante pode ser comparado à população normal e, inclusive, atrair ainda mais este grupo de asmáticos para a adesão ao programa.

Salienta-se também que os dados serão coletados de forma individual, mas que as análises serão feitas para o grupo, e, portanto, quando publicados não permitirão identificação individual de nenhum paciente.

Neste contexto, vimos solicitar a dispensa do TCLE, entendendo a importância da análise dos dados e a proteção individual dos participantes. 


\section{REFERÊNCIAS BIBLIOGRÁFICAS}

ABRAMSON, M.J.; BAILEY, M.J.; COUPER, F.J.; DRIVER, J.S.; DRUMMER, O.H.; FORBES, A.B.; MCNEIL, J.J.; HAYDN WALTERS, E. Victorian Asthma Mortality Study Group. Are asthma medications and management related to deaths from asthma? American Journal of Respiratory and Critical Care Medicine, v. 163, n. 1, p.12-18, 2001. Disponível em: https://www.ncbi.nlm. nih.gov/pubmed/ 11208619>. Acesso em: 5 dez. 2016.

AÏT-KHALED, N.; ENARSON, D.A.; OTTMANI, S.; EL SONY, A.; ELTIGANI, M.; SEPULVEDA, R. Chronic airflow limitation in developing countries: burden and priorities. International Journal of COPD, v. 2, n. 2, p. 141-150, 2007. Disponivel em: <https://www.ncbi.nlm.nih.gov/pmc/articles/PMC2695613/>. Acesso em: 2 dez. 2016.

ALVIM, C.G.; ANDRADE, C.R.; CAMARGO, P.A.M.; FONTES, M.K.F.; ANDRADE, L.C.; FREIRE, M.M.; FONSECA, M.M.; AZEVEDO, M.H.; SANTOS, R.M.; BEDRAN, R.M. Prevalência de gravidade de asma em adolescentes de Belo Horizonte. Revista Médica de Minas Gerais, v. 19, n. 4, p. 304-307, 2009. Disponível em: <http://rmmg.org/artigo/detalhes/438>. Acesso em: 7 jan. 2017.

AMARAL, L.M.; PALMA, P.V.; LEITE, I.C. Evolution of public policies and programs for asthma control in Brazil from the perspective of consensus guidelines. Jornal Brasileiro de Pneumologia, v. 38, n. 4, p. 518-525, 2012. Disponível em: <http://www.scielo.br/pdf/jbpneu/v38n4/en_v38n4a15.pdf>. Acesso em: 5 jan. 2017.

ARAÚJO, V.M.R. Monitoramento da qualidade do ar na região do Vale do Aço - MG: Municípios de Coronel Fabriciano e Ipatinga. Dissertação de Mestrado, Programa de Pós-Graduação em Engenharia Industrial, Centro Universitário do Leste de Minas Gerais, Coronel Fabriciano, Minas Gerais, Brasil, 2011. Disponivel em: <https://www.unilestemg.br/portal/mestrado/dissertacoes/dissertacao_030_ viviane.pdf>. Acesso em: 3 mar. 2017.

BAZK-WALCZAK, E.; JERZYŃSKA, J.; STELMACH, I.; KRAKOWIAK, J.;

STELMACH, W. Variability in the clinical profile of children with asthma referred to allergy clinic: a 10-year observation. Pneumonologia i Alergologia Polska, v. 79, n. 3, p. 189-195, 2011. Disponível em: <https://www.ncbi.nlm.nih.gov/pubmed/ 21509731>. Acesso em: 5 jan. 2017. 
BARRACLOUGH, R.; DEVEREUX, G.; HENDRICK, D. J.; STENTON, S. C. Apparent but not real increase in asthma prevalence during the 1990s. European Respiratory Journal, v. 20, n. 4, p. 826-833, 2002. Disponível em:

<http://erj.ersjournals.com/content/erj/20/4/826.full.pdf>. Acesso em: 3 dez. 2016.

BATEMAN, E.D.; JITHOO, A. Asthma and allergy a global perspective. Allergy, v. 62, n. 3, p. 213-215, 2007. Disponível em: <http://onlinelibrary.wiley.com/doi/ 10.1111/ j.1398-9995.2007.01324.x/abstract>. Acesso em: 10 jan. 2017.

BHULANI, N.; LALANI, S.; AHMEDA, A.; YAHYA JAN, Y.; FAHEEM, U.; KHAN, A.; SAMANI, Z.; AMAN, W.; BHATTI, F.; HAYAT, O.; SALEEM, S. Knowledge of asthma management by general practitioners in Karachi, Pakistan: comparison with international guidelines. Primary Care Respiratory Journal, v. 20, n. 4, p. 448-451, 2011. Disponível em: <https://www.ncbi.nlm.nih.gov/pubmed/2208 3538>. Acesso em: 5 nov. 2016.

BOULET, L.P.; FITZGERALD, J.M.; LEVY, M.L.; CRUZ, A.A.; PEDERSEN, S.; HAAHTELA, T.; BATEMAN, E.D. A guide to the translation of the Global Initiative for Asthma (GINA) strategy into improved care. European Respiratory Journal, v. 39, n. 5, p. 1220-1229, 2012. Disponível em: <https://www.ncbi.nlm.nih.gov/ pubmed/22282546?dopt=Abstract\&holding=npg>. Acesso em: 5 jan. 2017.

BOUSQUET, J.; CLARK, T.J.; HURD, S.; KHALTAEV, N.; LENFANT, C.; O'BYRNE, P.; SHEFFER, A. GINA guidelines on asthma and beyond. Allergy, v. 62, n. 2, p. 102-112, 2007. Disponível em: <https://www.ncbi.nlm.nih.gov/ pubmed/17298416>. Acesso em: 22 nov. 2016.

BRASIL. Ministério da Saúde. Secretaria Nacional de Ações Básicas. Estatísticas de saúde e mortalidade. Brasília: Ministério da Saúde, 2005.

BRASIL, Ministério da Saúde. Doenças respiratórias crônicas / Ministério da Saúde, Secretaria de Atenção à Saúde, Departamento de Atenção Básica. Brasília: Ministério da Saúde, 2010. Cadernos de Atenção Básica, 25. Série A. Normas e Manuais Técnicos). Disponível em <http://portal.saude.gov.br/portal/arquivos/pdf>. Acesso em: 20 dez. 2016.

BRITSH THORACIC SOCIETY/SIGN. Guideline on the management of asthma - a national guideline, out. 2014. Disponível em: <www.sign.ac.uk/pdf/sign141. pdf> Acesso em: 30 jan. 2015.

BROWNE, G.; LAM, L. Single dose intravenous salbutamol bolus for managing children with severe acute asthma in the emergency department: re-analysis of data. Pediatric Critical Care Medicine, v. 3, n. 2, p. 117-123, 2002. Disponível em: <https://www.ncbi.nlm.nih.gov/pubmed/12780979>. Acesso em: 12 dez. 2016. 
BUCKMASTER, R.A.; BOON, R. Reduce the rads: a quality assurance project on reducing unnecessary chest $X$-rays in children with asthma. Journal of

Paediatrics and Child Health, v. 41, n. 3, p. 107-111, 2005. Disponível em: <http://onlinelibrary.wiley.com/doi/10.1111/j.1440-1754.2005.00559.x/abstract>. Acesso em: 23 nov. 2016.

CAMPOS, H.S. Asma: suas origens, seus mecanismos inflamatórios e o papel do corticosteróide. Revista Brasileira de Pneumologia Sanitária, v. 15, n. 1, p. 47-60, 2007. Disponível em: <https://www.arca.fiocruz.br/handle/icict/10776>. Acesso em: 7 jan. 2017.

CARVALHO, W.B.; SOUZA, R.L.; SOUZA, N. Emergência e terapia intensiva pediátrica. 3. ed. Rio de Janeiro: Atheneu, 2014. p. 2887-97.

CASTILLO, F.; GARAY, J. Improving asthma management at the primary health care level. The Global Asthma Report, 2011. Disponível em:

<http://www.globalasthmareport.org/images/files/Global_Asthma_Report_ 2011.pdf>. Acesso em: 13 jan. 2017.

CASTRO-RODRIGUES, J.A.; HOLBERG, C.J.; WRIGHT, A.L.; MARTINEZ, F.D. A clinical index to define risk of asthma in yong children with recurrent wheezing. American Journal of Respiratory Critical Care Medicine, v.162, n.4, 2000. Disponível em: <http://www.atsjournals.org/doi/full/10.1164/ajrccm. 162.4.9912111>. Acesso em: 21 abr. 2017.

CERCI NETO, A. Avaliação dos programas de asma existentes no Brasil. In: CERCI NETO, A. Asma em saúde pública. Barueri, SP: Manole, 2007. p.43-56.

CERCI NETO, A.; FERREIRA FILHO, O.F.; BUENO, T. Exemplos brasileiros de programas de controle de asma. Jornal Brasileiro de Pneumologia, v. 34, n. 2, p. 103-106, 2008. Disponível em: <http://www.jornaldepneumologia.com.br/ detalhe_artigo.asp?id=583>. Acesso em: 16 jan. 2017.

CHATKIN, G.; CHATKIN, J.M.; FRITSCHER, C.C.; CAVALET-BLANCO, D.; BITTENCOURT, H.R.; SEARS, M.R. Asthma mortality in southern Brazil: is there a changing trend? Journal of Asthma, v. 44, p. 133-136, 2007. Disponível em: <https://www.ncbi.nlm.nih.gov/labs/articles/17454328/>. Acesso em: 23 nov. 2016.

COCKCROFT, D.W.; SWYSTUN, V.A. Asthma control versus asthma severity. Journal of Allergy and Clinical Immunology, v. 98, n. 6, p.1916-1918, 1996. Disponível em: <http://www.jacionline.org/article/S0091-6749(96)80185-0/ abstract>. Acesso em: 7 jan. 2017. 
COOKSON, W. The alliance of genes and environment in asthma and allergy. Nature, v. 25; n. 402, p. B5-11, 1999. Disponível em: <https://www.ncbi.nlm.nih. gov/pubmed/10586889>. Acesso em: 4 mar. 2017.

DEXHEIMER, J. W.; ABRAMO, T. J.; ARNOLD, D. H.; JOHNSON, K. B.; SHYR, Y.; YE, F.; FAN, K. H.; PALEL, N.; ARONSKY, D. An asthma management system in a pediatric emergency department. International Journal of Medical Informatics, v. 82, n. 4, p. 230-238, 2013. Disponível em: <https://www.ncbi.nlm. nih.gov/pmc/articles/PMC3646328/>. Acesso em: 15 out. 2016.

DONG, G.H.; MA, Y.N.; DING, H.L.; JIN, J.; CAO, Y.; ZHAO, Y.D.; HE, Q.C. Effects of housing characteristics and home environmental factors on respiratory symptoms of 10,784 elementary school children from Northeast China.

Respiration, v. 76, p.82-91, 2008. Disponível em: <https://www.ncbi.nlm.nih.gov/ pubmed/18337632>. Acesso em: 23 fev. 2017.

FARRAR, J.R. The global burden of asthma and current approaches to its management. European Pharmacotherapy, v. 126, p. 998-1000, 2005. Disponível em: <http://www.touchbriefings.com/pdf/1134/Farrar.pdf>. Acesso em: 12 mar. 2017.

FONTES, M. J. F.; AFONSO, A.G.A.; CALAZANS, G.M.Z.; ANDRADE, C.R.; LASMAR, L.M.L.B.J.; NADER, C.M.F.F.; CAMARGOS, P.A.M. Impacto de um programa de manejo da asma sobre as hospitalizações e os atendimentos de urgência. Jornal de Pediatria (Rio J.) [online]. v. 87, n. 5, p. 412-418, 2011. Disponível em: <http://www.scielo.br/scielo.php?script=sci_arttext\&pid=S002175572011000500008 >. Acesso em: 15 fev. 2017.

FONTES, M. J. F.; LASMAR, L. M. de L. B. F.; IBIAPINA C. da C.; CALAZANS, G. M. C.; ASSIS, I. de. Asma. In: LEÃO, E.; CORREAA, E.J.; MOTA, J. A. C.; VOANNA, M. B.; VASCONCELLOS, M. C. de. Pediatria ambulatorial. 5. ed. Belo Horizonte: Coopmed, 2013. p. 671-728.

FRESH, D.P. Radiation Risks to children from medical imaging. Revista Médica Clínica Las Condes, v. 24, n. 1, p. 15-20, 2013. Disponível em: $<$ http://www.elsevier.es/es-revista-revista-medica-clinica-las-condes-202-articuloradiation-risks-children-from-medical-S071686401370124X>. Acesso em: 16 mar. 2017.

FSFX/USISAUDE. Fundação São Francisco Xavier/Usisaúde. Programa Atitude rima com Saúde. Protocolo técnico do Projeto Respirar. Ipatinga, MG, 2013. 
GENTILE, N.T; UFBERG, J.; BARNUM, M.; MC HUGH, M.; KARVAS, D. Guidelines reduce $x$ ray and blood gas utilization in Acute Asthma. The American Journal of Emergency Medicine, v. 21, n. 6, p. 451-453, 2003. Disponível em: <http://www.ajemjournal.com/article/S0735-6757(03)00165-7/abstract>. Acesso em: 20 nov. 2016.

GERSHEL, J.C.; GOLDMAN, H.S.; STEIN, R.E. R.; SHELOV, S.P.; ZIPEKOWSKI, M. The usefulness of chest radiographs in first asthma attacks. The New England Jounal of Medicine, n. 309, p. 336-339, 1983. Disponível em: <http://www.nejm.org/doi/full/10.1056/NEJM198308113090603>. Acesso em: 23 nov. 2016.

GILDENHUYS, J; LEE, M.; ISBISTER, G. K. Does implementation of a paediatric asthma clinical practice guideline worksheet change clinical practice?

International Journal of Emergency Medicine, v. 2, n. 1, p. 33-39, 2009. Disponível em: <https://www.ncbi.nlm.nih.gov/pmc/articles/PMC2672973/>. Acesso em: 3 mar. 2017.

GINA. Global Iniciative for Asthma. Global strategy for asthma management and prevention. GINA Report, 2016. Disponível em: <http:www.ginasthma.org>. Acesso em: 16 jan. 2017.

GRIMM, L.J. Asthma Imaging. Drugs \& Diseases - radiology, mar. 2016. Disponível em: <emedicine.medscape.com/article/353436-overview>. Acesso em: 2 mar. 2017.

GUARNACCIA, S.; LOMBARDI, A.; GAFFURIN, A.; CHIARINI, M.; DOMENIGHINI, S.; D'AGATA, E.; SCHMACHER, R.F.; SPIAZZI, R.; NOTARANGELO, L.D. Application and implementation of the GINA asthma guidelines by specialist and primary care physicians: a longitudinal follow-up study on 264 children. Primary Care Respiration Journal, v. 16, n. 6. p. 357-362, 2007. Disponível em: <https://www.nature.com/articles/pcrj200777>. Acesso em: 28 jan. 2017.

HAAHTELA, T.; PIETINALHO, A. Finnish asthma and allergy programmes: Community problems need community actions. The Global Asthma Report, 2011. Disponível em: <http://www.globalasthmareport.org/images/files/Global_ Asthma_Report_2011.pdf>. Acesso em: 4 mar. 2017.

HALL, E.J. Radiation biology for pediatric radiologists. Pediatric Radiology, v. 39, sup. 1, p. 57-64, 2009. Disponível em: <https://www.ncbi.nlm.nih.gov/pubmed/ 19083223>. Acesso em: 23 nov. 2016.

IBGE. Instituto Brasileiro de Geografia e Estatística. Cidades. 2010. Disponível em: <http://cidades.ibge.gov.br/xtras/uf. php?lang=\&coduf=31\&search=minasgerais>. Acesso em: 13 dez. 2016. 
ISAAC. Initiative for asthma. Global strategy for asthma management and prevention. The Global Asthma Report. Paris, France. The International Union Against Tuberculosis and Lung Disease, 2011. Disponível em:

<http://isaac.auckland.ac.nz/resources/Global_Asthma_Report_2011.pdf>. Acesso em: 13 jan 2017.

JUCÁ, S.C.B.M.P.; TAKANO, O.A.; MORAES, L.S.L.; GUIMARÃES, L.V. Prevalência e fatores de risco para asma em adolescentes de 13 a 14 anos do Município de Cuiabá, Mato Grosso, Brasil. Caderno de Saúde Pública, v. 28, n. 4, p. 689-697, 2012. Disponível em: <http://livros01.livrosgratis.com.br/ cp095504.pdf>. Acesso em: 12 jan. 2017.

KALESNIKOFF, J.; GALLI, S.J. New developments in mast cell biology. Nature Immunology, v. 9, n. 11, p. 1215-23, 2008. Disponível em:

<https://www.ncbi.nlm.nih.gov/pubmed/18936782>. Acesso em: 12 jan. 2017.

KASHIWABARA, T.B. Programa "Respirar" em um município do Leste de Minas Gerais, Brasil. 2016. Tese de doutorado em Gestão. Universidade de Trás-os- Montes e Alto Doro. Portugal, 2016. Disponível em:

<https://www.ncbi.nlm.nih.gov/ pubmed/18936782>. Acesso em: 14 jan. 2017.

KASHIWABARA, T.B.; ROCHA, L.L.V.R.; SERQUEIRA, T. Avaliação econômica de um programa de controle e prevenção da asma. Revista UNINGÁ, v. 48, p. 61-75, 2016. Disponível em: <http://www.mastereditora.com.br/periodico/ 20160522_144147.pdf>. Acesso em: 3 mar. 2017.

KAWAKAMI, T.; KASHIWAKURA, J.; KAWAKAMI, Y. Histamine-Releasing Factor and Immunoglobulins in Asthma and Allergy. Allergy Asthma Immunology Research, v. 6, n. 1, p. 6-12, 2014. Disponível em: <https://www.ncbi.nlm.nih.gov/ pmc/articles/PMC3881402/>. Acesso em: 10 dez. 2016.

KIM, J.H.; ELLWOOD, P.H.; ASHER, M.I. International Study for Asthma and Allergies in Childhood - (ISAAC) Diet and asthma: looking back, moving forward. Respiratory, v. 10, p. 49-5, 2009. Disponível em: <https://respiratory-research. biomedcentral.com/articles/10.1186/1465-9921-10-49>. Acesso em: 11 dez. 2016.

KIM, J.E.; NEWMAN, B. Evaluation of a Radiation Dose Reduction Strategy for Pediatric Chest CT. American Journal of Roentgenology, v. 194, n. 5, p. 11881193, 2010. Disponível em: <https://www.ncbi.nlm.nih.gov/pubmed/20410401>. Acesso em: 5 mar. 2017.

KING, C.S.; MOORES, L.K. Clinical Asthma Syndroms and Important Asthma Mimics. Respiratory Care, v. 53, n. 5, p. 568-582, 2008. Disponível em:

<https://www.ncbi.nlm.nih.gov/pubmed/18426611>. Acesso em: 30 jan. 2017. 
KLEINERMAN, R.A. Cancer risks following diagnosis and therapeutic radiation exposure in children. Pediatric Radiology, v. 36, n. 2, p.121-125, 2006.

Disponível em: <https://www.ncbi.nlm.nih.gov/pmc/articles/PMC2663653/>. Acesso em: 13 dez. 2016.

KLIEGMAN, R.M.; BEHRMAN, R.E.; JENSON, H.B.; STANTON, B.F. Nelson textbook of pediatrics. Philadelphia: Saunders Elsevier, 2007.

KNAPPS, J. F.; SIMON, S.D.; SHARMA, V. Variation and trends in ED use of radiographs for asthma, bronchiolits, and croup in children. Abr. 2013.

Disponível em: <www.pediatrics.org/cgi/doi/10.1542/peds2013-0359>. Acesso em: 28 jan. 2016.

LASMAR, L.; FONTES, M.J.; MOHALLEN, M.T.; FONSECA, A.C.; CAMARGOS, P. Wheezy Child Program. The Experience of the Belo Horizonte Pediatric Asthma Management Program. World Allergy Organization Journal, v. 2, n. 179, p. 289295, 2009. Disponível em: <https://www.ncbi.nlm.nih.gov/pmc/articles/ PMC3651051/>. Acesso em: 3 mar. 2017.

LEMANSKE R.F JR.; BUSSE, W.W. Asthma. The Journal of Allergy and Clinical Immunology, v. 111, n. 2, p. S502-519, 2003. Disponivel em: <https://www.ncbi.nlm.nih.gov/pubmed/12592297>. Acesso em: 12 jan. 2017.

LEMANSKE R.F JR., BUSSE, W.W. Asthma: Clinical Expression and Molecular Mechanisms. Journal of Allergy and Clinical Immunology, v. 125, n. 2, p. 95102, 2010. Disponível em: <https://www.ncbi.nlm.nih.gov/pubmed/20176271>. Acesso em: 15 dez. 2016.

LIMA, W.L.; LEITE LIMA, N.E.V.C.; COSTA, M.R.S.R.; SANTOS, A.M.; SILVA, A.A.M.; COSTA, E.S. Asma e fatores associados em adolescentes de 13 e 14 anos em São Luís, Maranhão, Brasil. Caderno de Saúde Pública, v. 28, n. 6, p. 1046-1056, 2012. Disponível em: <http://www.scielo.br/scielo.php?script=sci arttext\&pid=S0102-311X2012000600004>. Acesso em: 16 jan. 2017.

LIMA, C.M.A.O.; MONTEIRO, A.M.V. Proteção radiológica à criança e ao adolescente. Revista Hospital Universitário Pedro Ernesto, v. 0 (supl.2) - $49^{\circ} \mathrm{cc}$ do HUPE. ago. 2011. Disponível em: <revista.hupe.uerj.br>. Acesso em: 9 fev. 2015.

LUNA, M.F.G.; ALMEIDA, P.C.; SILVA, M.G.C. Prevalência e associação de asma e rinite em adolescentes de 13 e 14 anos de Fortaleza, Ceará, Brasil. Cadernos de Saúde Pública, v. 27, n. 1, p. 103-112, 2011. Disponível em: <http://www.scielo.br/scielo.php?script=sci_arttext\&pid=S0102-311X2011000 100011>. Acesso em: 20 fev. 2017. 
MACEDO, S.E.C.; MENEZES, A.M.B.; KNORST, M.; DIAS-DA-COSTA, J.S.; GIGANTE, D.P.; OLINTO, M.T.A.; FISS, E. (2007). Fatores de risco para a asma em adultos, Pelotas, Rio Grande do Sul, Brasil. Cadernos de Saúde Pública, v. 23, n. 4, p. 863-874, 2007. Disponível em: <http://www.scielo.br/scielo.php? script=sci_arttext\&pid=S0102-311X2007000400014 >. Acesso em: 15 jan. 2017.

MASOLI, M.; FABIAN, D.; HOLT, S.; BEASLEY, R. Global Initiative for Asthma (GINA) Program. The global burden of asthma: executive summary of the GINA Dissemination Committee report. Allergy, v. 59, n. 5, p. 469-78, 2004. Disponível em: <https://www.ncbi.nlm.nih.gov/pubmed/15080825>. Acesso em: 5 jan. 2017.

MATHEUS, B.; SHAH, S.; CLEVELAND, R. H.; LEE, E. Y.; BACHUR, R. G.; NEUMAN, M. I. Clinical predictors of pneumonia among children with wheezing. Pediatrics, v. 124, n. 1, p.35, 2009. Disponível em: <http://pediatrics.aa ppublications.org/content/124/1/e29>. Acesso em: 15 dez. 2016.

MEDEIROS, D; SILVA, A.R.; RIZZO, J.A.; SARINHO, E; MALLOL, J; SOLÉ, D. Prevalência de sibilância e fatores de risco associados em crianças no primeiro ano de vida, residentes no Município de Recife, Pernambuco, Brasil. Cadernos de Saúde Pública, v. 27, n. 8, p. 1551-1559, 2011. Disponível em: <http://www.scielo.br/scielo.php?pid=S0102-311X2011000800010\&script= sci_abstract\&tlng=pt>. Acesso em: 28 jan. 2016.

MICHNE, S; JOHSTON, M. Changing clinical behavior by making guidelines specific. British Medical Journal, v. 328, n. 7.435, p. 343-345, 2004. Disponível em: <https://www.ncbi.nlm.nih.gov/pmc/articles/PMC338112/>.Acesso em: 7 fev. 2017.

MINAS GERAIS. Prefeitura Municipal de Ipatinga. Secretaria Municipal de Saúde. Projeto de reestruturação municipal da assistência pública à asma do município de Ipatinga. Ipatinga, MG, 2007.

MINAS GERAIS. Prefeitura Municipal de Ipatinga. Secretaria Municipal de Saúde. Protocolo de Atendimento Médico - Programa Respirar. Ipatinga, MG, 2015.

MOURA, B.L.A.; CUNHA, R.C.; AQUINO, R.; MEDINA, M.G.; MOTA, E.L.A.; MACINKO, J.; DOURADO, I. Principais causas de internação por condições sensíveis à atenção primária no Brasil: uma análise por faixa etária e região. Revista Brasileira de Saúde e Maternidade Infantil, v. 10, n. 1, p. 83-91, 2010. Disponível em: <http://www.scielo.br/scielo.php?pid=S1519-38292010000500008 \&script=sci_abstract\&tlng=pt>. Acesso em: 13 dez. 2016. 
NGUYEN, V.N.; CHAVANNES, N.; LE, L.T.; PRICE, D. The Asthma Control Test (ACT) as an alternative tool to Global Initiative for Asthma (GINA) guideline criteria for assessing asthmacontrol in Vietnamese outpatients. Primary Care

Respiratory Journal, v. 21, n. 1, p. 85-89, 2011. Disponível em:

<https://www.ncbi.nlm.nih.gov/pubmed/22027946>. Acesso em: 3 mar. 2017.

OLIVEIRA, F.R.; SILVA, L.M.; LOUZADA JR, P.; SANTI, W. (2003). Asma manejo da crise. Revista Médica de Ribeirão Preto, v. 36, n. 2, p. 404-408, 2003. Disponível em: <http://www.revistas.usp.br/rmrp/article/view/751>. Acesso em: 25 nov. 2016.

OPENEPI MENU. Estatísticas epidemiológicas de código aberto para a Saúde Pública. Disponível em: <www.openepi.com> Acesso em: 30 out. 2014.

PASSOS, S.D.; GAZETA, R.E.; FELGUEIRAS, A.P.; BENELI, P.C.; COELHO, M.S.Z.S. Do polluition and climate influence respiratory tract infections in children? Revista da Associação Médica Brasileira, v. 60, n. 3, p. 276-282, 2014. Disponível em: <http://www.scielo.br/scielo.php?script=sci_arttext\&pid=S010442302014000300276>. Acesso em: 20 dez. 2016.

PAWLINSKA-CHMARA, R.; WRONKA, I.; MUC, M. Prevalence and correlates of allergic diseases among children. Journal of physiology and pharmacology, v. 59, n. 6, p. 549-556, 2008. Disponível em: <http://jpp.krakow.pl/journal/archive/ 12_08_s6/pdf/549_12_08_s6_article.pdf>. Acesso em: 3 mar. 2017.

PEARCE, N.; AÏT-KHALED, N.; BEASLEY, R.; MALLOL, J.; KEIL, U.; MITCHELL, E.; COLIN, R. Worldwide trends in the prevalence of asthma symptoms: phase III of the International Study of Asthma and Allergies in Childhood (ISAAC). Thorax, v. 62, n. 9, p. 758-766, 2007. Disponível em: <https://researchonline.Ishtm.ac.uk/ 1515/1/758.pdf>. Acesso em: 20 dez. 2016.

PICKUP, C.M.; NEE, P.A.; RANDALL, P.E. Radiographic features in 1.016 adults admitted to hospital with acute asthma. Journal of Accident \& Emergency Medicine, v. 11, n. 4, p. 234, 1994. Disponível em: <https://www.ncbi.nlm.nih.gov /pmc/articles/PMC1342453/pdf/jaccidem00004-0028.pdf>. Acesso em: 3 mar. 2017.

PIOVESAN, D.M.; MENEGOTTO, D.M.; KANG, S.; FRANCISCATTO, E.; MILLAN, T.; HOFFMAN, C.; PASIN, L.R.; FISCHER, J.; BARRETO, S.S.M.; DALCIN, P.T.R. Avaliação prognóstica precoce da asma aguda na sala de emergência. Jornal Brasileiro de Pneumologia, v. 32, n. 1, p. 1-9, 2006. Disponível em: <http://www.scielo.br/scielo.php?script=sci_abstract\&pid=S1806$37132006000100004 \&$ Ing=en\&nrm=iso\&tlng=pt>. Acesso em: 7 jan. 2017. 
PIVA, J.P.; GARCIA, P.C.R.; AMANLÉIA, S.L. Asma aguda grave. In: CAMPOS JR., D.; BURNS, D.A.R.; LOPEZ, F.A. Tratado de pediatria, 3. ed. Barueri, São Paulo: Manole, 2015, p. 2887-2897.

PORTUGAL, Direcção-Geral da Saúde. Programa Nacional de Controlo da Asma. Lisboa: Direç̧ão-Geral da Saúde, 2008. Disponível em:

$<$ https://www.dgs.pt/outros-programas-eprojetos/paginas-de-sistema/saude-de-aa-z/programa-nacional-de-controlo-da-asma.aspx>. Acesso em: 23 nov. 2016.

PREFEITURA MUNICIPAL DE IPATINGA. História da cidade, 2016. Disponível em: <www.ipatinga.mg.gov.br/detalhe-da-materia/info/historia-da-cidade/9674>. Acesso em: 4 mar. 2017.

PREFEITURA MUNICIPAL DE IPATINGA. Centro de Formação Pedagógica (CENFOP), 2017. Disponível em: <https://ensfundamental1.wordpress.com/8052/>. Acesso em: 2 maio 2017.

PRIETSCH, S.O.M.; ZHANG, L.; CATHARINO, A.R.; VAUCHINSKI, L.; RODRIGUES, F. Mortalidade por asma em crianças brasileiras de até 19 anos de idade no período entre 1980 a 2007. Journal of Pediatrics, v. 88, n. 5, p. 384389, 2012. Disponível em: < http://www.scielo.org.bo/scielo.php?script =sci_arttext\&pid=S1024-06752014000300007>. Acesso em: 20 dez. 2016.

QUIMONEZ, R.A.; GARBER, M.D.; SCHROEDER, A.R.; ALVERSON, B.K.; NICKEL, W.; MCLEAN, H.S.; MITTAL, V.; PAPPAS, R.M.; PERCELAY, J.M.; PHILLIPS, S.C.; SHEN, M.; RALSTON, S.L. Choosing wisely in Pediatric Hospital Medicine: five opostinities for improved healthcare value. Jornal of Hospital Medicine, v. 8, n. 9, p. 479-85, 2013. Disponível em: <https://www.ncbi.nlm. nih.gov/pubmed/23955837>. Acesso em: 3 mar. 2017.

RAMOS, J. Médico de Família "ASMA". Disponível em: <http://media.rtp.pt/ agoranos/medico-de-familia/medico-de-familia->. Acesso em: 20 abr. 2017.

REED, M.D. Imaging utilization commentary: a radiology perspective. Pediatric Radiology, v. 38, n. 4, p. 660-663, 2008. Disponível em:

$<$ https://www.researchgate.net/publication/23273154_Imaging_utilization_commen tary_A_radiology_perspective>. Acesso em: 16 nov. 2016.

RIVERA, J.; FIERRO, N.A.; OLIVERA, A.; SUZUKI, R. New insights on mast cell activation via the high affinity receptor for IgE. Advanced Immunology, v. 98, p. 85-120, 2008. Disponível em: <https://www.ncbi.nlm.nih.gov/pubmed/18772004>. Acesso em: 12 abr. 2017. 
ROBACK, M.G.; DREITLEIN, D. A. Chest radiograph in the evaluation of first time wheezing episodes: review of current clinical practice and efficacy. Pediatric Emergency Care, v. 14, n. 3, p. 181-4, 1998. Disponível em:

<https://www.ncbi.nlm.nih.gov/pubmed/9655657>. Acesso em: 3 nov. 2016.

RUSHTON, A.R. The role of the chest radiograph in the management of chilhood asthma. Clinical Pediatrics, v. 21, n. 6, p. 325-328, 1982. Disponível em: <https://www.ncbi.nlm.nih.gov/pubmed/7075094>. Acesso em: 20 dez. 2016.

SEPÚLVEDA, R. Chile's de-medicalised programme for ACRD at the primary care level: Impact on asthma control. The Global Asthma Report. 2011. Disponível em: <http://www.globalasthmareport.org/images/files/Global_Asthma_Report_ 2011.pdf>. Acesso em: 29 abr. 2017.

SHAH, N.B.; PLATT, S.L. ALARA: is there a cause for alarm? Reducing radiation risks from computed tomography scanning in children. Current Opinion in Pediatrics, v. 20, n. 3, p. 243-7, 2008. Disponível em: <http://www.imagegently. org/portals/6/procedures/00008480-200806000-00003.pdf>. Acesso em: 3 mar. 2017.

SHEPHERD, M. Chest X-ray in acute wheeze. Starship Children's Health Clinical Guideline. Jun. 2010. Disponível em: <www.adhb.govt.nz>. Acesso em: 2 fev. 2015.

SILVA, E.C.F. Asma brônquica. Revista HUPE, v. 7, n.2, p. 33-57, 2008. Disponível em: <http://revista.hupe.uerj.br/detalhe_artigo.asp?id=202>. Acesso em: 23 nov. 2016.

SILVA, E.M.; SILVA, G.A. Mortalidade relacionada à asma no Município do Rio de Janeiro, Brasil, no período de 2000-2009: análise de causas múltiplas. Caderno de Saúde Pública, v. 29, n. 4, p. 667-680, 2013. Disponível em: <http://www.scielo.br/pdf/csp/v29n4/05.pdf>. Acesso em: 20 dez. 2016.

SIRCAR, G.; SAHA, B.; BHATTACHARYA, S.G.; SAHA, S. Allergic asthma biomarkers using systems approaches. Frontiers in Genetics, v. 4, n. 308, p. 110, 2014. Disponível em: <http://journal.frontiersin.org/article/10.3389/fgene. 2013.00308/full>. Acesso em: 7 jan. 2017.

SOLÉ, D. The International Study of Asthma and Allergies in Childhood (ISAAC): what have we learned? Jornal Brasileiro de Pneumologia, v. 31, n. 2, p. 93-94, 2005. Disponível em: < http://h-vml029.epm.br/bitstream/handle/11600/2504/ S1806-37132005000200001. pdf?sequence=1\&isAllowed=y>. Acesso em: 23 nov. 2016. 
SOLÉ, D.; CAMELO-NUNES, I. C.; WANDALSEN, G. F.; PASTORINO, A. C.; JACOB, C. M.; GONZALEZ, C.; WANDALSEN, N. F.; ROSÁRIO FILHO, N. A.; FICHER, G. B.; NASPITZ, C. K. Prevalence of symptons of asthma, rhinitis, and atopic eczema in Brazilian adolescents related to exposure to gaseous air pollutants and socioeconomic status. Journal of Investigational Allergology and Clinical Immunology, v. 17, n. 1, p. 6-13, 2007. Disponível em:

<https://www.ncbi.nlm.nih.gov/pubmed/17323857>. Acesso em: 5 jan. 2017.

SOLÉ, D.; CAMELO-NUNES, I.C.; WANDALSEN, G.F.; MALLOZI, M.C. A asma na criança e no adolescente brasileiro: contribuição do International Study of Asthma and Allergies in childhood (ISAAC). Revista Paulista de Pediatria, v. 32, n. 1, p. 114-125, 2014. Disponível em: <http://www.redalyc.org/pdf/4060/ 406034049018.pdf>. Acesso em: 20 dez. 2016.

SOLÉ, D.; WANDALSEN, G. F.; CAMELO-NUNES, I. C.; NASPITZ, C. K.; ISAAC - Grupo Brasileiro. Prevalence of symptoms of asthma, rhinitis, and atopic eczema among Brazilian children and adolescents identified by the International Study of Asthma and Allergies in Childhood (ISAAC) - Phase 3. Jornal de Pediatria, v. 82, n. 5, p. 341-6, 2006. Disponível em: <http://www.scielo.br/scielo. php?script=sci_arttext\&pid=S0021-75572006000600006>. Acesso em: 3 mar. 2017.

SBPT. Sociedade Brasileira de Pneumologia e Tisiologia (SBPT). Diretrizes da Sociedade Brasileira de Pneumologia e Tisiologia para o manejo da asma. Jornal Brasileiro de Pneumologia, v. 38, n. 1, p. S1-S46, 2012. Disponível em: <http://www.jornaldepneumologia.com.br/pdf/suple_200_70_38_completo_versao _corrigida_04-09-12.pdf>. Acesso em: 6 out. 2016.

STÄLLBERG, B.; LISSPERS, L.; HASSELGREN, M.; JANSON, C.; JOHANSSON, G.; SVÄRDSUDD, K. Asthma control in primary care in Sweden: a comparison between 2001 and 2005. Primary Care Respiration Journal, v. 18, n. 4, p. 279286, 2009. Disponível em: <https://www.nature.com/articles/pcrj200924>. Acesso em: 20 jan. 2017.

STEINKE, J.W.; RICH, S.S.; BORIS, L. Genetics of allergic disease. Journal of Allergy Clinical Immunology, v. 121, p. 384-7, 2008. Disponível em: <https://www.ncbi.nlm.nih.gov/pubmed/18241687>. Acesso em: 12 jan. 2017.

STURDY, P.M.; BUTLAND, B.K.; ANDERSON, H.R.; AYRES, J.G.; BLAND, J.M.; HARRISON, B.D.; PECKITT, C.; VICTOR, C.R. Deaths certified as asthma and use of medical services: a national casecontrol study. Thorax, v. 60, p. 909-915, 2005. Disponível em: <https://www.ncbi.nlm.nih.gov/pmc/articles/PMC1747248 /pdf/v060p00909.pdf>. Acesso em: 5 jan. 2017. 
TELLES FILHO, P. A. Asma brônquica. Diagnóstico da asma, 2017. Disponível em <http://www.asmabronquica.com.br/medical/diagnostico.html>. Acesso em: 2 mar. 2017.

TODO, A.S.; RODRIGUES JUNIOR, O. Fundamentos da proteção radiológica. Proteção radiológica. São Paulo, Instituto de Pesquisas Energéticas e Nucleares IPEN-CNEN/SP. Disponível em <www.ipen.br/ensino>. Acesso em: 10 nov. 2014.

TREGONING, J.S.; SCHWARZE, J. Respiratory Viral Infections in Infants: Causes, Clinical Symptoms, Virology, and Immunology. Clinical Microbiology Reviews, v. 23, n. 1, p. 74-98, 2010. Disponível em: <https://www.ncbi.nlm.nih. gov/ pmc/articles/PMC2806659/>. Acesso em: 5 nov. 2016.

TSAI, T.W.; GALLAGHER, E.J.; LOMBARDI, G.; GENNIS, P., CARTER, W.. Guidelines for the selective orgering of admission chest radiography in adult obstructive airway disease. Annals of Emergency Medicine, v. 22, n. 12, p. 1854-1858, 1993. Disponível em: <https://www.ncbi.nlm.nih.gov/pubmed /8239107>. Acesso em: 14 nov. 2016.

URRUTIA, I.; AGUIRRE, U.; SUNYER, J.; PLANA, E.; MUNIOZGUREN, N.; MARTÍNEZ-MORATALLA, J.; ANTO, J. M. Cambios en la prevalencia de asma en la población española del Estudio de Salud Respiratoria de la Comunidad Europea (ECRHS-II). Archivos de Bronconeumología, v. 43, n. 8, p. 425-430, 2007. Disponível em: <http://www.archbronconeumol.org/es/cambios-prevalenciaasma-poblacion-espanola/articulo-resumen/13108781/>. Acesso em: 5 jan. 2017.

WAKEFORD, R. The risk of childhood leukaemia following exposure to ionizing radiation. Journal of Radiological Protection, v. 33, n. 1, p. 1-25, 2013.

Disponível em: <https://www.ncbi.nlm.nih.gov/pubmed/23296257>. Acesso em: 23 nov. 2016.

WEHRMEISTER, F.C.; MENEZES, A.M.B.; CASCAES, A.M.; MARTÍNEZ-MESA, J.; BARROS, A.J.D. Tendência temporal de asma em crianças e adolescentes no Brasil no período de 1998 a 2008. Revista de Saúde Pública, v. 46, n. 2, p. 242249, 2012. Disponível em: <http://www.scielo.br/scielo.php?script=sci_arttext\& pid=S0034-89102012000200006 > . Acesso em: 7 mar. 2017. 